\title{
EFEITO DO TRATAMENTO DE SEMENTES COM PYROQUILON NO CONTROLE DE PATÓGENOS E DESENVOLVIMENTO DO ARROZ DE SEQUEIRO (Oryza sativa L.).
}

ODANIL MANOEL DE CAMPOS LEITE

Orientador: Prof. Dr. Geraldo José Aparecido Dario

\begin{abstract}
Dissertação apresentada à Escola Superior de Agricultura "Luiz de Queiroz", da Universidade de São Paulo, para a obtenção do Título de Mestre em Agronomia, Área de Concentração: Fitotecnia.
\end{abstract}

P I R A C I C A B A

Estado de São Paulo - Brasil

Fevereiro de 1997 
Dados Internacionais de Catalogação na Publicação (CIP) DIVISĀO DE BIBLIOTECA E DOCUMENTAÇĀO - Campus "Luiz de Queiroz"/USP

Leite, Odanil Manoel de Campos

Efei'o do tratamento de sementes com pyroqullon no controle de patógenos e desenvor imento do arroz de sequeiro (Oryza sativa L.) / Odanifi' Manoel de Campos '.eite. - - Piracicaba, 1997.

84 ).

Dissertação (mestrado) - - Escola Superior de Agricultura Luiz de Queiroz, 1997.

Bikl:-ngrafia.

1. Arroz de sequeiro 2. Brusone do arroz 3. Estimulante de cresc'nento 4.

Fungicida (Efeito) 5. Semente I. Título

CDD 633.18

631.563 


\section{EFEITO DO TRATAMENTO DE SEMENTES COM PYROQUILON NO CONTROLE DE PATÓGENOS E DESENVOLVIMENTO DO ARROZ DE SEQUEIRO (Oryza sativa L.).}

Aprovado em 05 de fevereiro de 1997.

Comissão julgadora: .

Prof. Dr. Geraldo José Aparecido Dario (Orientador)

ESALQ/USP

Prof. Dr. José Otávio Machado Menten

ESALQ/USP

Prof. Dr. José Ricardo Machado

UNESP/Botucatu

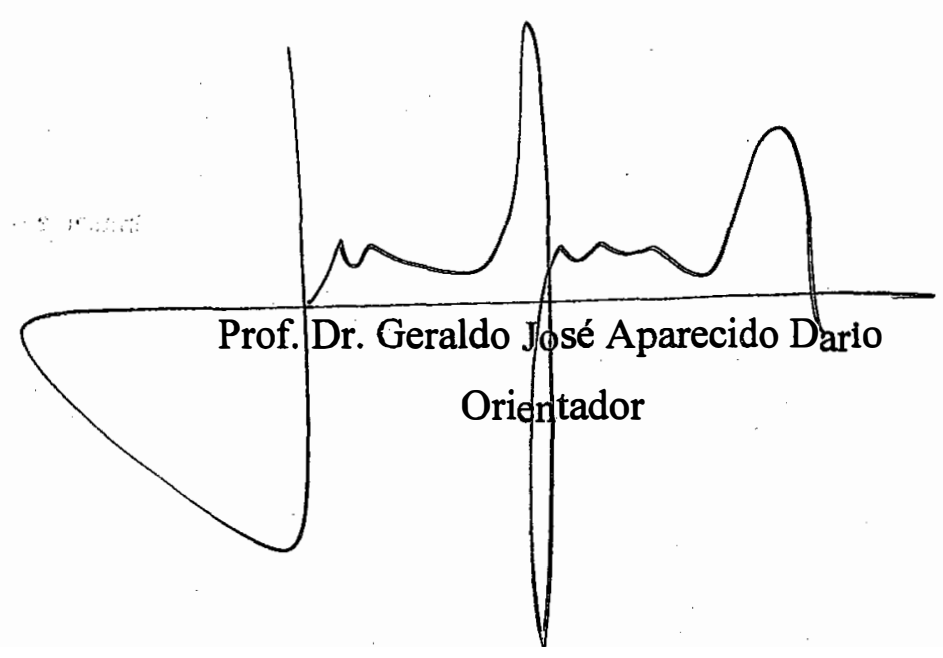


Nenhuma meta na vida é impossível de ser alcançada, quando se realmente quer atingi-la.

Eu dedico este trabalho

\author{
à minha mãe Nilda, \\ à minha esposa Marisa, \\ ao meu filho Felipe, \\ ao meu tio Manoel Carlos (em memória),
}

em agradecimento ao estímulo, apoio e amor que todos sempre me dedicaram. 


\section{AGRADECIMENTOS}

'A Ciba-Geigy Química S.A., pelo apoio e por ter acreditado na seriedade do meu trabalho, Ao Prof. Dr. Geraldo José Aparecido Dario, da ESALQ/USP, pela dedicação, orientação, e profissionalismo demonstrado durante o curso de mestrado,

Ao Prof. Dr. Durval Dourado Neto, da ESALQ/USP, pela colaboração no planejamento do experimento,

Ao Eng. Agr. Arlindo Pinheiro da Silveira, do Instituto Biológico de São Paulo, pela colaboração na execução do experimento em casa-de-vegetação,

Ao Eng. Agr. Lino Ricardo R. Furia, pós-graduando da ESALQ/USP, pela colaboração na digitação dessa dissertação,

À Dra. Ana Dionísia L. C. Novembre e Dra. Maria Heloísa Duarte de Moraes, da ESALQ/USP, pela colaboração nos testes de laboratório,

Ao Dr. Jaciro Soave, do Instituto Agronômico de Campinas, pela colaboração no planejamento do experimento em casa-de-vegetação,

Ao Sr. Orlando Pinheiro da Silveira pela colaboração na condução do experimento em casade-vegetação,

À Prof Maria Izalina Ferreira Alves, da ESALQ/USP pela orientação na análise estatística dos experimentos, 
Ao Eng. Agr. Celso Assis Machado, da Ciba-Geigy Química S.A., pelo apoio e incentivo. 


\section{SUMÁRIO}

LISTA DE TABELAS

RESUMO Xv

SUMMARY xvii

\section{INTRODUÇÃO} 1

2. REVISÃO DE LITERATURA. . .3

2.1 Considerações gerais sobre a cultura do arroz no Brasil. . .3

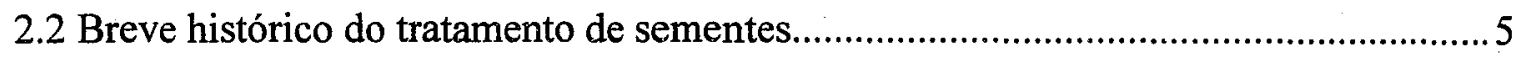

2.3 A importância do tratamento químico de sementes ......................................................... 6

2.4 Utilização do fungicida Pyroquilon na cultura do arroz ...............................................

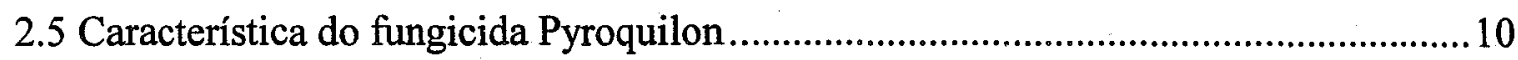

2.6 A deficiência hídrica como fator limitante da cultura de arroz...................................10

$2.7 \mathrm{O}$ tratamento químico de sementes e sua influência na tolerância à deficiência

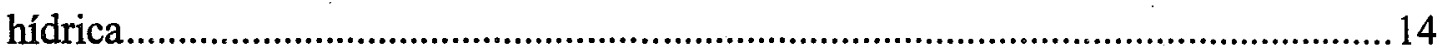

3. MATERIAL E MÉTODOS ...............................................................................................16

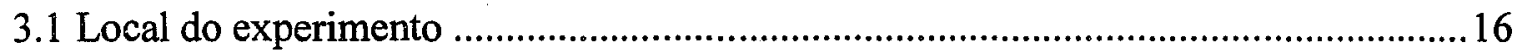

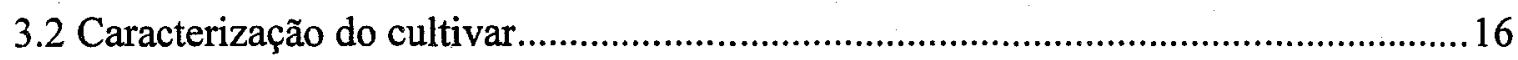

3.3 Caracterização das amostras de sementes................................................................ 16

3.4 Caracterização do fungicida Pyroquilon .................................................................... 18

3.5 Preparo e tratamento químico das amostras de sementes ..........................................18

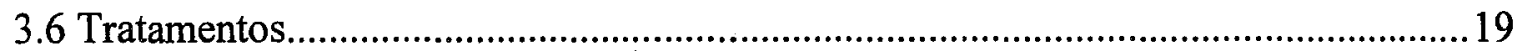

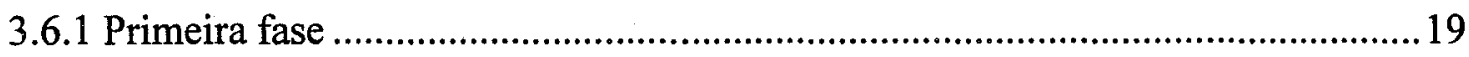

3.6.2 Segunda fase ..................................................................................................... 19

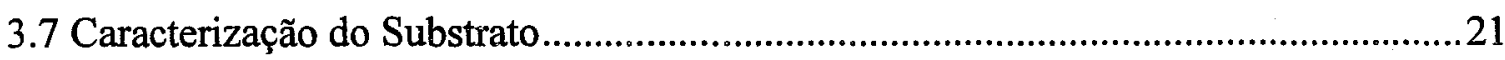

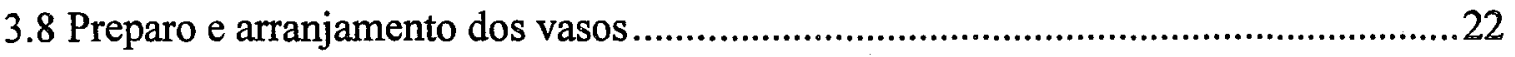

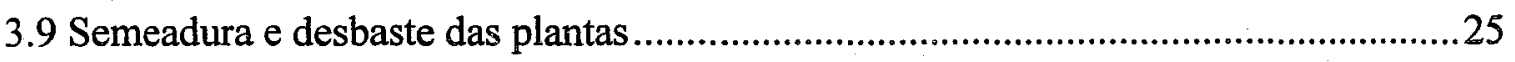

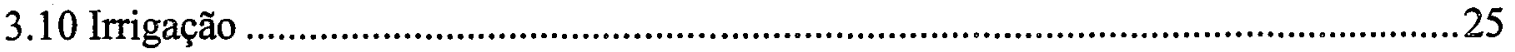




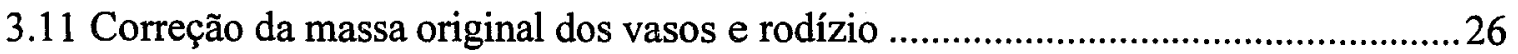

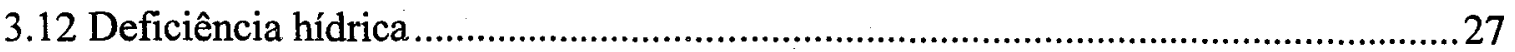

3.13 Controle e monitoramento das condições ambientes da casa-de-vegetação ..............27

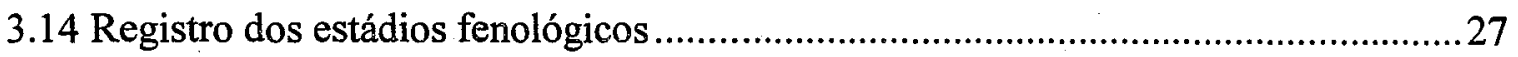

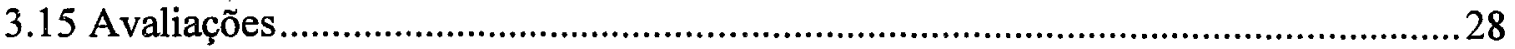

3.15.1 Análise de sanidade de sementes após o tratamento químico das sementes

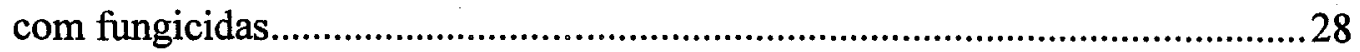

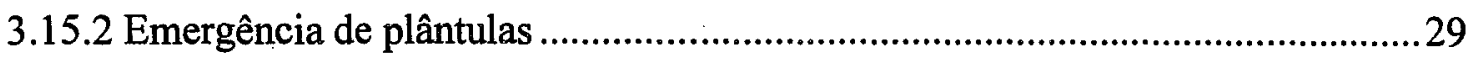

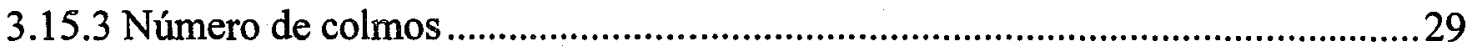

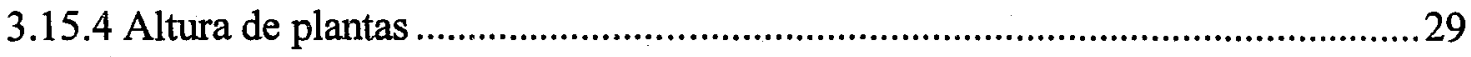

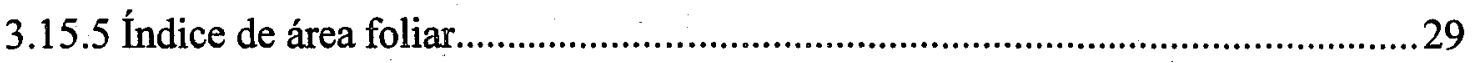

3.15.6 Número de panículas .......................................................................................30

3.15.7 Massa de raízes secas, de parte aérea seca (colmos e folhas), e de panículas

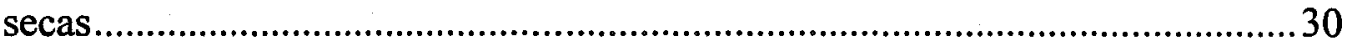

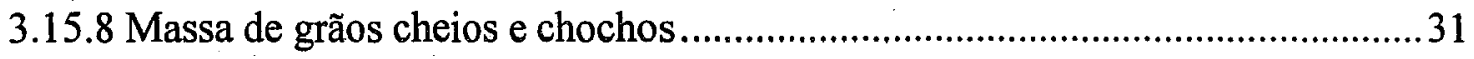

3.15.9 Número de grãos cheios e número de grão chochos e porcentagem de grão

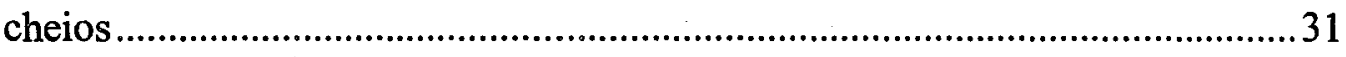

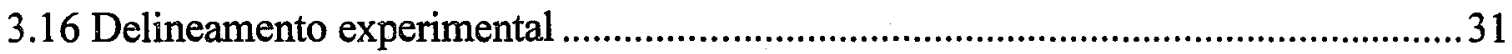

3.16.1 Experimento em laboratório (teste de sanidade de sementes tratadas) ...............31

3.16.2 Experimento em casa-de-vegetação ......................................................................... 32

4. RESULTADOS E DISCUSSÃO..................................................................................................39

4.1 Experimento em laboratório (teste de sanidade de sementes tratadas) .........................39

4.2 Experimento em casa-de-vegetação ..............................................................................4

4.2.1 Número de plantas emergidas (primeira fase) ....................................................4 42

4.2.2 Índice de área foliar, altura de plantas e número de colmos (primeira fase)........42

4.2.3 Índice de área foliar e número de panículas (segunda fase)...................................45

4.2.4 Massa de raízes secas, massa de parte aérea seca, e massa de panículas secas ...51

4.2.5 Massa de grãos cheios secos, massa de grãos chochos secos, número de grãos cheios, número de grãos chochos, e porcentagem de grãos cheios ......................60 
4.2.6 Número de colmos após a deficiência hídrica ...................................................73

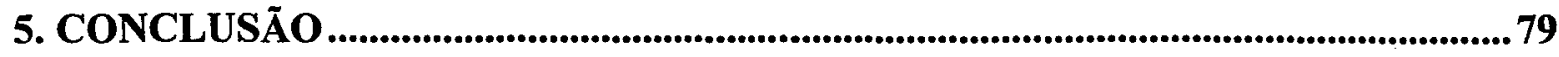

REFERÊNCIAS BIBLIOGRÁFICAS..............................................................................8 80 


\section{LISTA DE TABELAS}

Tabela 1. Resultados das análises de sementes das amostras de sementes IA68 e IA69 do cultivar IAC-165.

Tabela 2. Descrição dos patógenos presentes nas amostras de sementes IA68 e IA69 do cultivar IAC-165.

Tabela 3. Descrição dos tratamentos referentes à primeira fase. ............................................ 19

Tabela 4. Descrição dos tratamentos referentes à segunda fase..............................................20

Tabela 5. Resultado de análise química do substrato (macronutrientes)...............................21

Tabela 6. Resultado da análise química do substrato (micronutrientes).................................21

Tabela 7. Resultado de análise granulométrica do substrato (Método do Densímetro) .......22

Tabela 8. Descrição dos estádios fenológicos da cultura do arroz de sequeiro segundo a

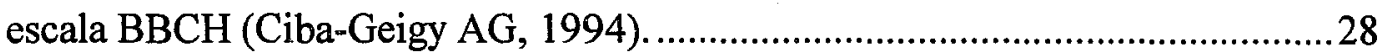

Tabela 9. Esquema de análise de variância referentes a variável porcentagem de sementes portadoras de patógenos.

Tabela 10. Esquema da análise da variância referente às variáveis índice de área foliar (IAF), altura de plantas (AP) e número de colmos (NC) (primeira fase).

Tabela 11. Descrição do esquema de análise da variância referente às variáveis IAF (índice de área foliar), NPAN (número de panículas), MRS (massa de raízes secas), MPAS (massa de parte aérea seca), MPS (massa de panículas secas), MGCS (massa de grãos cheios secos), MGCOS (massa de grãos chochos secos), NGC (número de grãos cheios), NGCO (número de grãos chochos), e \% GC (porcentagem de grãos cheios).

Tabela 12. Detalhamento da análise da variância, quando o teste $\mathrm{F}$ detectou diferença significativa entre os tratamentos, feito o desdobramento dos graus de liberdade em contrastes ortogonais de interesse.

Tabela 13. Análise de variância (quadrados médios) e teste $F$, para a variável porcentagem de sementes portadoras de Pyricularia oryzae, Phoma sp., 
Trichoconiella padwickii, e Fusarium sp. (dados transformados em $\operatorname{arcoseno} \sqrt{y / 100}$ ). .39

Tabela 14. Análise de variância (quadrados médios) e teste $F$, para a variável porcentagem de sementes portadoras de Drechslera oryzae, Aspergillus spp., Penicillium spp., e Rhinchosporium oryzae. (dados transformados em $\operatorname{arcoseno} \sqrt{y / 100})$.

Tabela 15. Médias sem transformação e teste de Tukey para tratamentos, para a variável porcentagem de sementes portadoras de Pyricularia oryzae, Phoma sp., Trichoconiella padwickii, e Fusarium sp.

Tabela 16. Médias não transformadas e teste de Tukey para tratamentos, para a variável porcentagem de sementes portadoras de Drechslera oryzae, Aspergillus spp., Penicillium spp., e Rhinchosporium oryzae.

Tabela 17. Descrição do número de plantas emergidas por tratamento (primeira fase)

Tabela 18. Análise da variância (Quadrados médios) e teste $\mathrm{F}$ para as variáveis. Índice de área foliar (IAF), altura de plantas em $\mathrm{cm}(\mathrm{AP})$ e número de colmos (NC), (primeira fase).

Tabela 19. Médias sem transformação e teste de Duncan, para as variáveis IAF (índice de área foliar), AP (altura de plantas em $\mathrm{cm}$ ) e NC (número de colmos), (primeira fase).

Tabela 20. Análise da variância (quadrados médios) e teste $\mathrm{F}$ para as variáveis índice de área foliar (IAF) e número de panículas (NPAN), (segunda fase).

Tabela 21. Desdobramento dos graus de liberdade de tratamentos (quadrados médios) em contrastes ortogonais, e teste $\mathrm{F}$, para as variáveis IAF (indice de área foliar) e NPAN (número de panículas), (segunda fase).

Tabela 22. Descrição das estimativas dos contrastes relativos ao índice de área foliar (IAF) e seus indicativos.

Tabela 23. Descrição das estimativas dos contrastes relativos ao número de panículas e seus indicativos. 
Tabela 24. Descrição das estimativas dos contrastes para o grupo de variáveis IAF (índice de área foliar) e NPAN (número de panículas), (segunda fase).

Tabela 25. Médias sem transformação e teste de Duncan para tratamentos, para as variáveis índice de área foliar médio (IAF) e número de panículas (NPAN), (segunda fase).

Tabela 26. Análise da variância (Quadrados médios) e teste F para as variáveis Massa de raízes secas (MRS), Massa de parte aérea seca (MPAS) e Massa de panículas secas (MPS), (segunda fase).

Tabela 27. Desdobramento dos graus de liberdade de tratamentos (quadrados médios) em contrastes ortogonais, e teste $\mathrm{F}$, para as variáveis MRS (massa de raízes secas), MPAS (massa de parte aérea seca) e MPS (massa de panículas secas), (segunda fase).

Tabela 28. Descrição das estimativas dos contrastes relativos à massa de raízes secas (MRS, g/vaso).

Tabela 29. Descrição das estimativas dos contrastes relativos à massa de parte aérea seca (MPAS, g/vaso).

Tabela 30. Descrição das estimativas dos contrastes relativos à massa de panículas secas (MPS, g/vaso).

Tabela 31. Resumo das estimativas dos contrastes para o grupo de variáveis massa de raízes secas (MRS), massa de parte aérea seca (MPAS) e massa de panículas secas (MPS), (segunda fase).

Tabela 32. Médias sem transformação e teste de Duncan para tratamentos, para as variáveis MRS (massa de raízes secas, g/vaso), MPAS (massa de parte aérea seca, $\mathrm{g} / \mathrm{vaso}$ ) e MPS (massa de panículas secas, $\mathrm{g} / \mathrm{vaso}$ ), (segunda fase).

Tabela 33. Análise da variância (quadrados médios) e teste $F$ para as variáveis Massa de grãos cheios secos (MGCS, g/vaso), Massa de grãos chochos secos (MGCOS, g/vaso), Número de grãos cheios (NGC), Número de grãos chochos (NGCO), e Porcentagem de grãos cheios (\% GC), (segunda fase). 
Tabela 34. Desdobramento dos graus de liberdade de tratamentos em contrastes ortogonais (quadrados médios), e teste $\mathrm{F}$, para as variáveis MGCS (massa de grãos cheios secos), MGCOS (massa de grãos chochos secos), NGC (número de grãos cheios), NGCO (número de grãos chochos) e \% GC (porcentagem de grãos cheios), (segunda fase).

Tabela 35. Descrição das estimativas dos contrastes relativos à massa de grãos cheios secos (MGCS, g/vaso).

Tabela 36. Descrição das estimativas dos contrastes relativos à massa de grãos chochos secos (MGCOS, g/vaso).

Tabela 37. Descrição das estimativas dos contrastes relativos ao número de grãos cheios (NGC).

Tabela 38. Descrição das estimativas dos contrastes relativos ao número de grãos chochos (NGCO).

Tabela 39. Descrição das estimativas dos contrastes relativos a porcentagem de grãos cheios (\% GC).

Tabela 40. Resumo das estimativas dos contrastes para o grupo de variáveis MGCS (massa de grãos cheios secos), MGCOS (massa de grãos chochos secos), NGC (número de grãos cheios), NGCO (número de grãos chochos) e \% GC (porcentagem de grãos cheios), (segunda fase).

Tabela 41. Médias sem transformação e teste de Duncan para tratamentos, para as variáveis MGCS (massa de grãos cheios secos), MGCOS (massa de grãos chochos secos), NGC (número de grãos cheios), NGCO (número de grãos chochos) e \% GC (porcentagem de grãos cheios), (segunda fase).

Tabela 42. Análise da variância e teste $\mathrm{F}$ para a variável número de colmos (NC), (segunda fase).

Tabela 43. Desdobramento dos graus de liberdades de tratamentos em contrastes ortogonais, e teste $\mathrm{F}$, para a variável NC (número de colmos), dentro de cada época de avaliação, (segunda fase). 
Tabela 44. Médias sem transformação e teste de Duncan para épocas de avaliações, para a variável NC (número de colmos), (segunda fase)..............................................76

Tabela 45. Médias sem transformação e teste de Duncan, para os tratamentos dentro de cada avaliação, da variável NC (número de colmos), (segunda fase). 


\title{
EFEITO DO TRATAMENTO DE SEMENTES COM PYROQUILON NO CONTROLE DE PATÓGENOS E DESENVOLVIMENTO DO ARROZ DE SEQUEIRO (Oryza sativa L.).
}

\author{
Autor: Odanil Manoel de Campos Leite \\ Orientador: Prof. Dr. Geraldo José Aparecido Dario
}

\section{RESUMO}

No presente trabalho utilizou-se o fungicida sistêmico Pyroquilon $50 \mathrm{PM}$, do grupo químico das Quinolinas, em tratamento de sementes de arroz de sequeiro. Foram tratados dois lotes de sementes do cultivar IAC-165, com e sem incidência de Pyricularia oryzae Cav. O experimento conduzido em casa-de-vegetação, apresentou duas fases distintas, sendo o ponto divisório das fases o pleno florescimento da cultura. Quatro regimes de irrigação foram usados: sem deficiência hídrica, com deficiência hídrica provocados aos 10 e 5 dias antes e 5 dias após o pleno florescimento. Para compor os tratamentos foram utilizadas duas amostras de sementes de arroz, uma com alta incidência de Pyricularia oryzae Cav. e outra com baixa incidência do patógeno, parte das sementes foram tratadas com o fungicida Pyroquilon e a outra permaneceu sem tratamento.

$\mathrm{O}$ objetivo principal do trabalho foi avaliar a atividade fungicida e fitoestimulante do Pyroquilon, aplicado em tratamento de sementes, na planta de arroz, bem como o seu efeito no aumento da tolerância da planta de arroz a um período de deficiência hídrica.

As avaliações feitas foram: teste de sanidade de sementes, índice de área foliar, altura de plantas, número de colmos, número de panículas, massa de raízes secas, massa de panículas secas, massa da parte aérea seca, massa de grãos cheios e chochos secos, número de grãos cheios e chochos e porcentagem de grãos cheios. 
Os resultados obtidos permitem concluir que o Pyroquilon, quando aplicado em tratamento de sementes de arroz de sequeiro, controla eficazmente o patógeno Pyricularia oryzae Cav., e tem influência positiva, mesmo quando as sementes apresentam baixa incidência de Pyricularia oryzae Cav., estimulando o desenvolvimento vegetativo, atuando como um fitoestimulante, no entanto quando ocorrem períodos de deficiência hídrica, particularmente próximo ao pleno florescimento, o efeito fitoestimulante do Pyroquilon não é suficiente para compensar os efeitos deletérios da deficiência hídrica. 


\title{
SEED TREATMENT WITH THE SYSTEMIC FUNGICIDE PYROQUILON 50 PM AND ITS INFLUENCE ON UPLAND RICE (Oryza sativa L.) DEVELOPMENT AND DROUGHT TOLERANCE
}

\author{
Author: Odanil Manoel de Campos Leite \\ Adviser: Prof. Dr. Geraldo José Aparecido Dario
}

\section{SUMMARY}

A systemic fungicide of the Quinolines group (Pyroquilon 50 PM) was tested in upland rice seed treatment. Two seed samples of rice, cultivar IAC-165, were treated. One of the samples with high incidence of Pyricularia oryzae Cav. and the other one with low incidence of the pathogen. The greenhouse experiment had two distinct phases, the division point was the full-flowering stage. Four different irrigation schedule were used: without water stress, with induced water stress 10 and 5 days before and 5 days after full-flowering. To compose the treatment the two samples of seeds were divided in two parts one was treated with Pyroquilon and another remained untreated.

The main purpose of this research was to evaluate the fungicide activity and the stimulating effects of Pyroquilon 50 PM on rice plants originated from treated seeds, as well as its effects on drought tolerance.

It was evaluated during the experiment development: blotter test, leaf area index, number of stems, number of panicles, among other parameters.

It could be concluded that Pyroquilon 50 WP controls Pyricularia oryzae Cav. with high eficcacy, it has also a positive influence when used in upland rice seed treatment, even when the seeds were not with high incidence of Pyricularia oryzae Cav..

Although, the product did not show any effects on the plant drough tolerance. 


\section{INTRODUÇÃo}

O arroz é um dos mais importantes cereais cultivados no mundo, com área inferior apenas ao trigo.

No Brasil a cultura ganha destaque na cesta básica, uma vez que, grande parte das calorias ingeridas diariamente pela população é suprida pelo arroz, sendo que atualmente são cultivados no país ao redor de 4,0 milhões de hectares, aproximadamente $77 \%$ da área é ocupada pela lavoura conduzida no sistema de sequeiro.

Alguns problemas são limitantes no sistema de sequeiro, como a baixa fertilidade dos solos, acidez e toxidez por alumínio, e problemas fitossanitários, mas principalmente a falta de águạ. em períodos considerados críticos para a cultura, tem sido o principal fator de decréscimo de rendimento.

Por ser uma planta semi-aquática, a água exerce papel muito importante no desenvolvimento vegetativo e reprodutivo da cultura do arroz, e quando ocorrem períodos de deficiência hídrica, principalmente durante o florescimento, os prejuízos em geral, são muito acentuados, dependendo da intensidade e duração do período de deficiência hídrica.

Associado à deficiência hídrica, a ocorrência de doenças na cultura do arroz de sequeiro é outro fator extremamente importante para a produção, sendo a brusone, causada pelo fungo Pyricularia oryzae Cav., considerada no Brasil a doença mais importante.

Esse patógeno é disseminado principalmente através do vento e da água, mas as sementes desempenham também um importante papel nessa disseminação. $O$ tratamento químico de sementes é recomendado pela pesquisa, como meio de controle desse patógeno, e dentre os fungicidas inclui-se Pyroquilon, produto sistêmico do grupo químico da Quinolinas.

O Pyroquilon tem ação sistêmica, com penetração através do tegumento das sementes, sendo também absorvido pelas raizes e translocado para a parte aérea das plantas através de movimento acropetal. Seu modo de ação é a inibição da biossíntese da melanina de diversos fungos, e sua ação protetiva pode se extender por até 50 dias após a emergência da cultura, controlando inclusive a brusone foliar. 
Além do controle da brusone tem-se observado também, em campos de produção de arroz, cujas sementes foram tratadas com Pyroquilon, um maior vigor das plantas, mesmo sem a ocorrência de brusone, e esse maior vigor, em alguns casos, tem refletido em maior rendimento de grãos de arroz.

Este trabalho teve como objetivo verificar o efeito fungicida do Pyroquilon, usado em tratamento de sementes de arroz de sequeiro, contra Pyricularia oryzae Cav. e outros patógenos presentes nas sementes, e também a influência fitoestimulante desse fungicida na planta de arroz e seu efeito no aumento de tolerância da mesma à diferentes períodos de deficiência hídrica ocorrentes ao redor do pleno florescimento. 


\section{REVISÃO DE LITERATURA}

\subsection{Considerações gerais sobre a cultura do arroz no Brasil}

No Brasil o arroz é cultivado em aproximadamente 4 milhões de hectares em todo o território. Ocupa a terceira maior área cultivada, entre as culturas de grãos, perdendo apenas para o milho e a soja.

O arroz (Oryza sativa L.), alimento básico de $40 \%$ da humanidade, provendo 12 a $35 \%$ das calorias e 9 a $25 \%$ das proteínas totais ingeridas, respectivamente, pelos latinoamericanos e asiáticos, ocupa posição de destaque entre os principais cereais cultivados, sendo apenas suplantado em área cultivada e em produção pelo trigo.

A região de produção de arroz abrange uma grande extensão no mundo. Hoje no mundo o arroz é cultivado desde a latitude de $49^{\circ}$ Norte até a latitude de $35^{\circ} \mathrm{Sul}$, em locais ao nível do mar, até locais com mais de $3.000 \mathrm{~m}$ de altitude, sendo cultivado em grande parte dessas áreas na forma de arroz de sequeiro (Krishnasamy \& Seshu., 1987).

Os países que mais se destacam como maiores produtores de arroz no mundo São China, seguida pela Índia, já o Brasil responde apenas por $2 \%$ da produção mundial desse cereal.

Fornasieri Filho \& Fornasieri (1993) relataram, que no Brasil são utilizados três sistemas no plantio da cultura de arroz, sendo classificados pelo suprimento de água. O sistema irrigado, que é feito em terras baixas irrigadas por inundação controlada; o sistema de várzeas úmidas, que é feito em terras baixas onde a irrigação provém da precipitação pluvial ou do afloramento do lençol freático, permanecendo o solo saturado durante, pelo menos, parte do ciclo da cultura; e o sistema de sequeiro, que é feito em terras firmes sem irrigação onde a água é proveniente de precipitação pluvial permanecendo o solo drenado durante todo o ciclo da cultura.

Da área total brasileira, aproximadamente $77 \%$ é cultivada através do sistema de sequeiro resultando em 54\% da produção nacional (Prabhu et al., 1993). 
Brusone é considerada como o mais sério problema fitossanitário do arroz. Esta doença não ocorre apenas em longos períodos de seca, mas a suscetibilidade da cultura pode aumentar após um período de estresse hídrico.

Os registros das ocorrências de brusone afetando a cultura do arroz são muito antigos. Ou (1985) relatou que na China, Soong Ying-Shin em seu livro "Utilização dos recursos naturais", publicado em 1637, já relatava a ocorrência dessa doença com o nome de "doença da febre do arroz". Segundo o autor esta doença apresenta a maior capacidade destrutiva, dentre as doenças ocorrentes na cultura do arroz.

Souza et al. (1984) relataram que as perdas causadas por brusone podem chegar até $100 \%$ em algumas lavouras.

Os sintomas nas folhas ocorrem inicialmente como pequenos pontos castanhos, que logo aumentam de tamanho, podendo atingir até $2 \mathrm{~cm}$ de comprimento por $0,5 \mathrm{~cm}$ de largura. As lesões típicas são fusiformes, com o centro cinza e os bordos de cor marrom, circundados, às vezes, por um halo amarelado. Com o aumento do número e tamanho das lesões, essas se coalescem e produzem a queima das folhas e a morte das plantas na fase vegetativa. Nos nós dos colmos aparecem manchas de coloração marrom e nos entrenós manchas de formato elíptico, causando necrose da parte atingida, impedindo a circulação da seiva. A infecção do nó da base da panícula, conhecida como brusone do pescoço, pode causar esterilidade, desde que o ataque seja após sua emissão, ou durante a fase leitosa dos grãos. Pode ainda causar a redução da massa dos grãos, quando o ataque 'as panículas for mais tardio.

Pinheiro \& Guimarães (1990), estudaram o índice de área foliar e rendimento de arroz de sequeiro registraram maior intensidade de brusone durante os períodos sem precipitação.

Shahjahan et al. (1987) relataram que a maioria dos casos de ocorrência de brusone sugere que o patógeno pode sobreviver em diferentes regiões climáticas. Em clima tropical, o período de molhamento das folhas, e a presença de orvalho ou chuva, é considerada como ótima condição microclimática para o desenvolvimento da doença. Esses autores afirmam também, que além do elemento climático, outros fatores como tipo de solo, resistência 
varietal e práticas culturais, podem influenciar sensivelmente no desenvolvimento da brusone.

Prabhu \& Guimarães (1990) estudaram o efeito da brusone nas folhas e nas panículas e no rendimento de grãos de cinco cultivares de ciclo curto e nove de ciclo longo, em condições de sequeiro, e verificaram que a altura, e a matéria seca das plantas foram reduzidas significativamente nos cultivares de ciclo curto. As perdas médias de massa de 1.000 grãos variaram de $8 \%$ a $14 \%$ e a percentagem de grãos vazios, de $19 \%$ a $58 \%$, tanto nos cultivares de ciclo curto quanto nos de ciclo longo. As perdas na produtividade variaram entre $15 \%$ a $38 \%$.

\subsection{Breve histórico do tratamento de sementes}

Jeffs (1986), Soave \& Wetzel (1987) e Dhingra et al. (1980) relataram que, o tratamento de sementes para a proteção de plantas contra insetos e doenças visando garantir uma boa produção remonta da antigüidade. Nos tempos romanos de Plínio (60 D.C.), já se usava o vinho e folhas trituradas de ciprestes para o tratamento de sementes.

A imersão de sementes de trigo em salmoura, e misturadas em seguida com cal, era praticada na Inglaterra no ano de 1733 por Jethro Tull, para prevenir o aparecimento dos carvões e cáries na cultura de trigo (Jeffs, 1986; Soave \& Wetzel, 1987 e Dhingra et al., 1980).

Em 1750, Tillet, na França, após pesquisas com o uso de soda cáustica e cal no tratamento de sementes para o controle de Tilletia caries no trigo, obteve tanto sucesso que esta prática tornou-se recomendação oficial (Jeffs, 1986; Soave \& Wetzel, 1987 e Dhingra et al., 1980).

Os métodos de tratamento de sementes foram evoluindo com o passar do tempo, já em 1761, Schulthuss introduziu o uso do sulfato de cobre no tratamento de sementes, sendo esta uma nova alternativa adotada por muitos pesquisadores, no entanto esse composto não se mostrou de todo eficiente especialmente contra os carvões do trigo (Jeffs, 1986; Soave \& Wetzel, 1987 e Dhingra et al., 1980). 
Em 1897, Bolley nos Estados Unidos, introduziu o uso do formaldeído como ágente tratador de sementes no controle do carvão da aveia. Esse método tornou-se muito usado, apesar de sua fitotoxicidade às sementes (Jeffs, 1986; Soave \& Wetzel, 1987 e Dhingra et al., 1980).

Em 1914, Rheime na Alemanha, introduziu os fungicidas organomercuriais no tratamento de sementes de trigo, em 1942, o produto Thiram conhecido e usado até hoje foi lançado no mercado (Jeffs, 1986; Soave \& Wetzel, 1987 e Dhingra et al., 1980).

$\mathrm{Na}$ década de 50 ocorreu a introdução do Carboxin primeiro fungicida sistêmico para tratamento de sementes. Já nos anos 60 foi lançado no mercado o Benomil, também outro fungicida sistêmico (Jeffs, 1986; Soave \& Wetzel, 1987 e Dhingra et al., 1980).

Em anos mais recentes, na década de 80 , ocorreu a introdução dos fungicidas triazóis em tratamento de sementes, que tem como representante mais conhecido o Triadimenol (Jeffs, 1986).

O Pyroquilon também foi lançado no final dos anos 80, sendo seu principal uso o arroz (Ciba-Geigy Química S.A., 1990).

\subsection{A importância do tratamento químico de sementes}

A boa semente, que deve ser necessariamente sadia ou livre de patógenos e insetos, é um dos pilares fundamentais da agricultura moderna, sendo o tratamento de sementes prática obrigatória na implantação de uma determinada cultura agrícola (Menezes, 1985).

$\mathrm{O}$ tratamento de sementes com fungicidas na cultura do arroz de sequeiro nas áreas mais tecnificadas é prática comum, visando o controle de diversos patógenos, dentre eles o mais importante é Pyricularia oryzae (Lucca, 1985).

A principal razão diz respeito aos microrganismos associados às sementes, geralmente fungos, como é o caso de Colletotrichum sp. em soja, Fusarium spp. em milho, Aspergillus spp. em amendoim, Macrophomina sp. em feijão, Helminthosporium spp. em trigo, e outros (Galli et al., 1980; Menezes, 1985 e Lucca, 1985). Esses microrganismos podem apodrecer as sementes, matar as plântulas, ou induzir a produção de plântulas anormais. 
Fungos também presentes no solo, tais como Pythium spp., Phytophthora spp. e Rhizoctonia spp., também causam semelhantes problemas (Soave \& Wetzel, 1987; Jeffs, 1986; Dhingra et al). Tanto os fungos nas sementes quanto no solo, podem levar à uma diminuição de estande da cultura e consequentemente diminuição do rendimento, e a introdução de patógenos em áreas isentas faz-se com muita eficácia através de sementes infectadas (Menezes, 1985 e Lucca, 1985).

Além disso os fungos presentes nas sementes são fonte de inóculo para futuras epidemias nas lavouras, como é o caso de Helminthosporium spp. em sementes de trigo (Forcelini, 1990); ainda segundo o mesmo autor, tratamento químico de sementes em alguns casos podem controlar fungos, mesma estes não sendo transportados por sementes, como acontece com Erysiphe sp. em trigo e cevada.

Nakamura \& Sader (1986) e Amaral et al. (1985) descreveram inúmeros patógenos que podem ser transmitidos por sementes na cultura do arroz e seus efeitos na qualidade dos grãos e sementes. Ainda Nakamura \& Sader (1985), estudaram o efeito da infecção por fungos na germinação e vigor de sementes de arroz das cultivares IAC-25, IAC-47, IAC164, IAC-165 e IAC-1278, verificaram que lotes com baixa incidência de Phoma sp., Drechslera sp. e Pyricularia oryzae, apresentavam maior porcentagem de germinação e vigor, em relação às com infecção mais elevada. Já os cultivares que apresentavam alta incidência de Phoma sp. e Drechslera sp. demonstravam menor porcentagem de germinação e menor resistência ao envelhecimento acelerado.

Muito poucos pesquisadores estudaram o efeito de diversos fungicidas utilizados em tratamento de sementes na cultura de arroz para controle de patógenos.

Sartorato et al. (1990) trabalharam em condições de laboratório com o cultivar IAC-165 na safra 85/86, e utilizaram sementes naturalmente portadoras de Phoma sp., submeteram essas sementes ao tratamento com os fungicidas: Benomil (200 g de ingrediente ativo $/ 100 \mathrm{~kg}$ de sementes), Iprodione (200 $\mathrm{g}$ de ingrediente ativo/100 kg de sementes) e Captan ( $267 \mathrm{~g}$ de ingrediente ativo/100 kg de sementes), sendo que o Benomil foi o melhor tratamento contra esse patógeno, sem no entanto ser erradicante. 
Cicero et al. (1993) trabalharam com sementes de arroz do cultivar IAC-25 em condições de laboratório e campo utilizando-se dos seguintes tratamentos fungicidas: Carboxin+Thiram $(50+50,60+60$ e $93.75+93.75 \mathrm{~g}$ de ingrediente ativo $/ 100 \mathrm{~kg}$ de sementes), Thiram ( $140 \mathrm{~g}$ de ingrediente ativo/100 $\mathrm{kg}$ de sementes) e Thiabendazol (20g de ingrediente ativo/100 kg de sementes). Os autores avaliaram os efeitos dos produtos sobre a qualidade fisiológica e sanitária das sementes tratadas, 'e concluíram, que em laboratório os materiais tratados e não tratados com fungicidas não apresentaram diferenças em relação à qualidade fisiológica, já em campo, o produto Thiram aumentou a porcentagem e a velocidade de emergência das plântulas oriundas de sementes tratadas em relação às sementes não tratadas, e quanto ao controle dos patógenos presentes nas sementes, todos os tratamento foram eficazes, com destaque para a mistura Carboxin + Thiram que controlou totalmente os patógenos Pyricularia oryzae, Drechslera oryzae e Rhynchosporium oryzae.

De acordo com Prabhu \& Guimarães (1990), apesar da transmissão de Pyricularia oryzae Cav. pelas sementes infectadas ser considerada difícil, essas podem constituir fontes de inóculo primário nas lavouras de primeiro ano. Os mesmos autores demonstram ainda, que embora o principal modo de disseminação do patógeno seja pelo vento, o tratamento de șementes com fungicida é uma prática recomendável, pois além de reduzir o inóculo primário, protege as plantas na fase mais suscetível.

Lasca et al. (1983), avaliaram a eficiência de produtos fungicidas em tratamento de sementes de arroz para o controle de Pyricularia oryzae e Phoma sp., utilizando sementes do cultivar IAC-47, proveniente de Mato Grosso do Sul, comprovadamente infectadas. As sementes foram tratadas com os fungicidas Vitavax (Carboxin 75\% PM): $300 \mathrm{~g}$ do ingrediente ativo por $100 \mathrm{~kg}$ de sementes; Benlate (Benomyl 50\% PM): $100 \mathrm{~g}$ do ingrediente ativo por $100 \mathrm{~kg}$ de sementes e Terra-Coat 205 (PCNB + Terrazole 5,8\%): 400 $\mathrm{g}$ do ingrediente ativo por $100 \mathrm{~kg}$ de sementes. Os resultados mostraram a eficácia de todos os tratamentos na sanidade das sementes, reduzindo o nível de infecção, sendo que a germinação das sementes não foi afetada pelos tratamentos fungicidas. 


\subsection{Utilização do fungicida Pyroquilon na cultura do arroz}

Poucos trabalhos foram desenvolvidos no Brasil com o fungicida Pyroquilon em tratamento de sementes para o controle de doença do arroz. O principal patógeno alvo do Pyroquilon é Pyricularia oryzae, pois este fungicida apresenta uma especificidade muito acentuada para o controle deste patógeno, embora também controle Phoma spp. e Trichoconiella padwickii entre outros patógenos (Ciba-Geigy Química S.A., 1990).

Muitos benefícios podem ser obtidos com o uso do Pyroquilon em tratamento de sementes de arroz. Pyroquilon em sementes de arroz utilizado no controle de Pyricularia oryzae, proporciona superioridade na germinação, vigor, massa de 100 sementes, germinação na primeira contagem, germinação total, velocidade de emergência e massa da matéria seca da raiz quando comparadas às sementes portadoras de Pyricularia oryzae. As sementes de arroz com Pyricularia oryzae apresentaram uma menor capacidade germinativa e vigor do que as sementes isentas do patógeno, mostrando que realmente esse patógeno afeta seriamente a qualidade das sementes (Cornélio, 1991).

Filippi \& Prabhu (1989), estudaram o fungicida Pyroquilon no tratamento de sementes de arroz de sequeiro dos cultivares IAC-25, IAC-165 e IAC-47, infectadas por Pyricularia oryzae, e verificaram que o fungicida na dose de $400 \mathrm{~g}$ de ingrediente ativo por $100 \mathrm{~kg}$ de sementes reduziu consideravelmente a infecção foliar de todos os cultivares em relação à sementes não tratadas não tratada, com eficácia entre 40 e 45 dias após a semeadura, verificaram ainda que um aumento de rendimento de até $500 \mathrm{~kg}$ de grãos por hectare pode ser obtido no cultivar IAC-165 em relação à sementes não tratadas.

Prabhu \& Guimarães (1993), também estudaram o controle de brusone através da aplicação de Pyroquilon em tratamento de sementes. Em nível de campo, a aplicação de Pyroquilon ( $400 \mathrm{~g}$ do ingrediente ativo por $100 \mathrm{~kg}$ de semente) controlou a brusone, cujo ataque restringiu-se a níveis inferiores a $5 \%$ aos 38 dias após a semeadura dos cultivares suscetíveis IAC 47, IAC 25, IAC 164 e L-50. Observaram também que o tratamento de sementes não apresentou resposta nos cultivares mais resistentes à brusone. Finalmente 
concluíram que o tratamento de sementes com Pyroquilon é um meio adequado de proteção de plantas de arroz contra brusone durante a fase vegetativa para os cultivares suscetíveis.

\subsection{Característica do fungicida Pyroquilon}

O Pyroquilon é um fungicida sistêmico do grupo químico dos Derivados das Quinolinas, cujo modo de ação baseia-se na inibição da síntese de melanina nos apressórios do patógeno Pyricularia oryzae, impedindo dessa forma a penetração do mesmo nos tecidos do hospedeiro. O Pyroquilon também impede a esporulação do patógeno em lesões já desenvolvidas bloqueando a produção de conídios. O Pyroquilon é absorvido pelas raízes das plantas e translocado acropetalmente para os tecidos das folhas e colmos (Ciba-Geigy Química S.A., 1990).

\subsection{A deficiência hídrica como fator limitante da cultura de arroz}

A resistência à seca pelo arroz é a expressão total da sua habilidade em sobreviver, crescer e por fim produzir grãos sob uma condição de deficiência hídrica durante um período do ciclo da cultura (Chang \& Vergara, 1975)

Após extensa revisão sobre resistência à seca, do milheto, sorgo, milho e arroz, os citados autores concluem, que as principais características que interferem no mecanismo de resistência são: escape (fechamento estomático em resposta ao estresse, resistência cuticular e sistema radicular) e tolerância (ao calor e à dessecação). A capacidade de escape à seca depende da habilidade da planta em absorver água suficiente ou de repor suas perdas cedo o bastante para evitar o estresse dos seus tecidos, e a resistência à seca ou tolerância 'a dessecação é resultado da habilidade das células sobreviverem e metabolizarem mesmo quando os tecidos já se encontram ligeiramente dessecados.

Pereira et al. (1994) enfatizam que a deficiência hídrica afeta todos os aspectos do crescimento das plantas, alterando sua morfologia e fisiologia. Os seus efeitos estão relacionados com o decréscimo da pressão de turgescência, e dos potenciais hídrico e 
osmótico. A deficiência hídrica reduz a fotossíntese, através da desidratação do protoplasma, e limita a translocação dos carbohidratos e dos hormônios de crescimento.

O'Toole \& Garrity (1984) descrevem que o arroz de sequeiro sempre sofre algum grau de deficiência hídrica devido a perda de água por transpiração, e esses autores ainda relataram, que fenologicamente a semente que possue entre $10 \%$ a $15 \%$ de teor de água é muito tolerante a um estresse hídrico interno, entretanto $o$ estágio inicial de desenvolvimento (da germinação ao estabelecimento das plântulas é o mais vulnerável períodos do ciclo da cultura à deficiência hídrica. O período de crescimento vegetativo é menos sensivel 'a falta de água internamente na planta, no entanto ocorre a redução da área foliar e da altura dos colmos, reduzindo também a atividade fotossintética.

Renard \& Alluri (1981) analisando o efeito do estresse hídrico sobre a condutância estomática, potencial de água e características da folha, observaram que, quando os efeitos da seca são evidentes a superfície inferior da folha é mais afetada do que a superior, devido ao enrolamento da folha. Quando a parte superior da folha é enrolada para dentro seus estômatos ficam mais abertos do que os da parte inferior, presumivelmente respondendo a modificação microclimática onde a demanda evaporativa é baixa.

Os sintomas mais comuns da deficiência hídrica são enrolamento das folhas, secamento das pontas das folhas, redução do perfilhamento e do crescimento das plantas, retardamento da floração, aumento da esterilidade e redução da massa dos grãos (Fageria, 1984; Fornasieri Filho \& Fornasieri, 1993).

O balanço hídrico de uma cultura de arroz de sequeiro é determinado pelo balanço entre a chuva e a evapotranspiração, e quando a evapotranspiração excede a chuva ocorre a deficiência de água, sendo que arroz consome a máxima quantidade de água ao redor de uma semana antes do florescimento. Em relação ao consumo total de água o arroz consome $30 \%$ na fase vegetativa, $55 \%$ na fase reprodutiva e $15 \%$ na fase de maturação. A planta de arroz é muito sensível à deficiência hídrica no período que vai do estádio de divisão/redução até a floração, e os efeitos da deficiência hídrica nesse período são esterilidade, decréscimo da massa dos grãos e diminuição da produção. A deficiência hídrica na fase vegetativa propicia redução devido ao decréscimo do número de panículas, 
mas quando a deficiência hídrica ocorre na fase reprodutiva, o rendimento é menor devido a diminuição da massa dos grãos e também a maior esterilidade, Fageria (1984) relata que a deficiência hídrica reduz a produção, no entanto essa redução depende de alguns fatores tais como: o estádio de desenvolvimento em que ocorre a deficiência hídrica, a sua severidade e duração.

Vieira et al. (1991) relataram que a sensibilidade da cultura do arroz ao estresse hídrico é mais prejudicial no início do florescimento, e em menor intensidade durante o desenvolvimento da panícula e dos grãos.

A ocorrência de períodos de seca, chamados de veranicos, durante o cultivo do arroz de sequeiro é muito comum nas regiões produtoras do Brasil. Fornasieri Filho \& Fornasieri (1993) citando diversas fontes, demonstram que existe grande probabilidade de ocorrência no Brasil Central, de períodos de seca de treze dias uma vez ao ano, de oito dias três vezes ao ano, e ainda períodos de vinte e dois dias de estiagem podem ocorrer uma vez ao ano a cada sete anos.

Pesquisas com arroz de sequeiro desenvolvidas no Centro Nacional de Pesquisa de Arroz e Feijão da Empresa Brasileira de Pesquisa Agropecuária (CNPAF/EMBRAPA) demonstram que um alto índice de área foliar (IAF) pode acentuar o efeito das estiagens, resultando em menor rendimento da cultura (Stone et al., 1979; Pinheiro et al., 1990).

Pinheiro et al. (1990) relataram que o baixo rendimento médio do arroz de sequeiro tem sido atribuído basicamente 'as ocorrências de estiagens no período reprodutivo e da Brusone causada pelo fungo Pyricularia oryza. Os dados obtidos por Pinheiro et al. (1990) indicam que mesmo na ausência desses estresses, sérias limitações são impostas pelo simples estabelecimento de um baixo índice de área foliar. Esses autores ainda demonstram que os valores de índice de área foliar inferiores a 2,0 minimizam as perdas por deficiênca hídrica, mas também restringem o potencial produtivo a valores inferiores a $1.500 \mathrm{~kg} / \mathrm{ha}$. Portanto, mesmo na ausência dos fatores ambientes limitantes, o simples estabelecimento de um baixo índice de área foliar já torna possível obter um alto rendimento de grãos pela cultura. Para índice de área foliar acima de 3,0 a deficiência hídrica no período reprodutivo resultou em quebras de rendimento superiores a $40 \%$, 
quando valores de índice de área foliar superiores a 6,0 ocorreram, associados a alta pluviosidade e a dias encobertos no período reprodutivo os rendimentos foram inferiores a $2.500 \mathrm{~kg} / \mathrm{ha}$

Pereira et al. (1994) estudando dois cultivares de arroz IAC-165 e IAC-47 em diferentes níveis de umidade avaliaram diversos parâmetros de rendimento e concluíram que a diminuição do conteúdo de água no solo reduziu a área foliar, o comprimento e o número de panículas, o número de espiguetas por panícula, a massa de raízes secas, a massa de parte aérea seca, a produção de matéria seca total e a produção de grãos. Concluíram ainda que a influência do regime hídrico sobre os componentes de produção obedeceram a seguinte ordem decrescente: número de panículas por planta, número de espiguetas por panícula, e massa de 1.000 grãos. Por fim colocam que o limite mínimo de conteúdo de água do solo, nas fases vegetativa e reprodutiva, para não causar redução acentuada no rendimento de grãos, foi correspondente a $70-80 \%$ da capacidade de campo.

Stone et al. (1984) testando em vaso o efeito de quatro lâminas de água e a presença ou não de vermiculita no solo, para dois cultivares de arroz, observaram que a deficiência hídrica reduziu o número de grãos cheios por panícula, a massa de grãos, o rendimento de grãos e de matéria seca total, e a altura de plantas, e aumentou a porcentagem de grãos chochos, duração do ciclo e a relação de raiz/colmo.

O aumento da porcentagem de grãos vazios é resultante do aumento de esterilidade de flores, provocada pelo estresse hídrico nos estádios de meiose ou na antese. A redução no número de grãos cheios, por sua vez, é resultado do aumento de esterilidade (Stone et al., 1984).

Ma \& Lu. (1990) em um ensaio com arroz híbrido Shanyou número 6, realizaram os seguintes tratamentos: fornecimento de água intermitente, irrigação até o florescimento, irrigação até 15 e 38 dias após do florescimento, e estudaram a senescência e atividade fisiológica das plantas. Nos tratamentos em que a irrigação foi suspensa antes do florescimento, sensíveis reduções foram observadas na atividade fisiológica, acúmulo de matéria seca nos grãos e na porcentagem de grãos cheios, indicando que quanto mais cedo a água era retirada maiores eram as reduções. A irrigação contínua proporcionou um aumento 
de produção de 7,4 a $28,3 \%$ acima dos demais tratamentos, devido ao retardamento da senescência radicular, aumento da taxa fotossintética, aumento do período de acúmulo de matéria seca no grão e aumento na porcentagem de grãos cheios.

\subsection{O tratamento químico de sementes e sua influência na tolerância à deficiência hídrica}

Poucos trabalhos foram desenvolvidos com a utilização de produtos químicos em tratamento de sementes de arroz objetivando medir influências positivas ou negativas sobre o desenvolvimento das plantas oriundas dessas sementes, tão pouco uma melhor tolerância à deficiência hídrica. Não se encontra em literatura nenhum trabalho correlacionando fungicida aplicado em tratamento de sementes e sua influência na tolerância da planta de arroz a seca, ou comportamento das plantas oriundas de sementes tratadas em diferentes condições de suprimento hídrico.

Alguns trabalhos com $\mathrm{CaCl}_{2}$ e $\mathrm{KCl}$ aplicados em tratamento de sementes podem ser encontrados em literatura, no entanto esses produtos não são fungicidas.

Biswas et al. (1982) relataram que existe uma variação gradual no potencial de água da folha em plantas de arroz sob condições de estresse hídrico durante a transição da fase vegetativa para a fase reprodutiva, mas o tratamento de sementes com $\mathrm{CaCl}_{2}$ aumenta a retenção de água em plantas com estresse. $O$ estresse hídrico induz a uma grande redução no conteúdo de clorofila, proteína, e RNA e aumenta o conteúdo de aminoácidos livres e prolina nas plantas. $O$ crescimento das plantas tornaram-se menos dependentes do tratamento com cálcio com $\mathrm{o}$ avanço da idade. Uma redução significativa nos parâmetros de rendimento foi observada nas plantas com estresse hídrico, mas o tratamento das sementes com cálcio compensou consideravelmente parte da perda de rendimento.

Sen \& Misra (1981) utilizaram em experimento com trigo (cv. Kalyan Sona), sementes tratadas com $0,25 \%$ de $\mathrm{CaCl}_{2}, 2,5 \% \mathrm{KCl}$ e água e verificaram que o rendimento de grãos mostrou correlação positiva com a turgidez relativa, conteúdo total de clorofila e freqüência estomática, e se correlacionou de forma negativa com a taxa de transpiração e a abertura estomática, a turgidez relativa apresentou correlação positiva com o conteúdo total 
de clorofila e a freqüência estomática, e uma correlação negativa com a abertura estomática e a taxa de transpiração. A abertura estomática apresentou uma correlação negativa com todos os caracteres, com a exceção da taxa de transpiração. A correlação positiva entre o conteúdo total de clorofila, freqüência estomática e turgidez relativa depende da capacidade de retenção de água , que por sua vez depende da redução da taxa de transpiração.

Alguns outros poucos produtos químicos foram também estudados em tratamento de sementes visando verificar sua influência no comportamento das mesmas à diferentes condições de suprimento hídrico.

Wang \& Shen (1991) utilizando sementes de arroz embebidas em uma solução de $200 \mathrm{ppm}$ de um inibidor de crescimento de multi-efeito (triazole), sendo posteriormente secas em germinadores, e a água no substrato mantida constante durante o estágio de três folhas por dois dias, verificaram que as sementes tratadas apresentaram um desenvolvimento mais rápido quando foram hidratadas novamente. 


\section{MATERIAL E MÉTODOS}

\subsection{Local do experimento}

O experimento foi desenvolvido em casa-de-vegetação com controle de temperatura e umidade relativa do ar, instalada na Fazenda Mato Dentro do Instituto Biológico de São Paulo, cuja latitude, longitude e altitude do local são respectivamente $20^{\circ}$ 54' Sul, $47^{\circ} 4^{\prime}$ Oeste de Greenwich e $693 \mathrm{~m}$.

\subsection{Caracterização do cultivar}

O cultivar de arroz de sequeiro utilizado foi o IAC-165, desenvolvido pelo Instituto Agronômico de Campinas, com maior área cultivada no Brasil dentre os materiais melhorados. Seu ciclo cultural é de aproximadamente 109 dias, apresentando o primórdio floral e floração aos 53 dias e 77 dias, respectivamente; altura média de plantas de 104,5 $\mathrm{cm}$, largura média e comprimento médio das folha de $17 \mathrm{~mm}$ e $426 \mathrm{~mm}$, respectivamente; . coloração das folhas verde, e sem pubescência; o grão é do tipo longo, com massa de 1000 grãos de $28,7 \mathrm{~g}$; e alta suscetibilidade à Brusone (Fonseca \& Bebendo, 1984).

\subsection{Caracterização das amostras de sementes}

Foram utilizados duas amostras de sementes certificadas de arroz de sequeiro, uma amostra com incidência de Pyricularia oryzae e outra sem, do cultivar IAC-165 produzidas pelo IAC (Instituto Agronômico de Campinas), de numeração IA68 e IA69, 1995.

A amostra IA68 foi produzida na Estação Experimental de Capão Bonito, e amostra IA69 foi produzida na Estação Experimental de Pindamonhangaba, ambas as estações situadas no estado de São Paulo.

As análises das amostras de sementes de qualidade (germinação, envelhecimento acelerado e teste de frio com solo) e sanidade, foram realizadas nos laboratórios de Análise de Sementes do Departamento de Agricultura e pelo Laboratório de Patologia de Sementes 
do Departamento de Fitopatologia, respectivamente, ambos da Escola Superior de Agricultura "Luiz de Queiroz", de acordo com as Regras para Análise de Sementes (Ministério da Agricultura e Reforma Agrária, 1992) e Marcos Filho et al. (1987). Os resultados obtidos estão descritos na Tabela 1 e Tabela 2.

Tabela 1. Resultados das análises de sementes das amostras de sementes IA68 e IA69 do cultivar IAC-165.

\begin{tabular}{cccc}
\hline Lote & Germinação (\%) & Envelhecimento Acelerado (\%) & Teste de frio com solo (\%) \\
\hline IA68 & 84 & 73 & 57 \\
IA69 & 85 & 90 & 77 \\
\hline
\end{tabular}

Tabela 2. Descrição dos patógenos presentes nas amostras de sementes IA68 e IA69 do cultivar IAC-165.

\begin{tabular}{ccc}
\hline Patógenos & Lote IA68 (incidência em \%) & Lote IA69 (incidência em \%) \\
\hline Pyricularia oryzae & 30 & 2 \\
Phoma sp. & 23 & 3 \\
Trichoconiella padwickii & 0 & 27 \\
Fusarium spp. & 2 & 3 \\
Drechslera oryzae & 5 & 19 \\
Aspergillus spp. & 14 & 1 \\
Penicillium spp. & 2 & 1 \\
Rhinchosporium oryzae & 0 & 24 \\
\hline
\end{tabular}




\subsection{Caracterização do fungicida Pyroquilon}

No tratamento químico das sementes foi utilizado o fungicida sistêmico Pyroquilon, desenvolvido pela Ciba-Geigy Química S.A., do grupo químico da Quinolinas, formulação pó-molhável contendo $500 \mathrm{~g}$ de Pyroquilon por quilograma do produto. A dose empregada foi a oficial de registro, ou seja, $400 \mathrm{~g}$ do ingrediente ativo por $100 \mathrm{~kg}$ de sementes.

\subsection{Preparo e tratamento químico das amostras de sementes}

As amostras foram passadas por um homogeneizador de sementes tipo Boerner. Após a homogeneização, as amostras foram separadas em duas subamostras de $5 \mathrm{~kg}$ cada e acondicionados em sacos de papel tipo "craft". As subamostras foram armazenados em câmara fria e seca, a uma temperatura de $15^{\circ} \mathrm{C}$ e umidade relativa do ar de $35 \%$, no Laboratório de Análise de Sementes da ESALQ/USP, e mantidos por quinze dias nessas condições até o tratamento químico efetuado um dia antes da semeadura.

Uma das subamostras de ambas as amostras de sementes sofreu tratamento químico com o fungicida Pyroquilon, a dose utilizada foi a de registro para a cultura do arroz ( $400 \mathrm{~g}$ do ingrediente ativo por $100 \mathrm{~kg}$ de sementes).

Para ser feito o tratamento as sementes foram colocadas sobre uma mesa coberta com plástico, e umedecidas com água destilada na proporção de $1 \%$ (1 litro de água destilada por $100 \mathrm{~kg}$ de sementes). Em seguida o fungicida foi adicionado homogeneamente sobre as sementes, e para melhor distribuição do produto foi feita uma agitação da massa de sementes durante cinco minutos.

Após o tratamento as sementes foram secas a sombra por 24 horas, e foi realizada nova análise de sanidade de sementes no Laboratório de Patologia de Sementes da ESALQ/USP. 


\subsection{Tratamentos}

\subsubsection{Primeira fase}

Essa fase compreende o período da semeadura até 10 dias antes do pleno florescimento da cultura. Os tratamentos encontram-se na Tabela 3.

Tabela 3. Descrição dos tratamentos referentes à primeira fase.

\begin{tabular}{cl}
\hline Tratamento & \multicolumn{1}{c}{ Descrição } \\
\hline A & Sementes com Pyricularia oryzae e não tratadas com fungicida* \\
B & Sementes sem Pyricularia oryzae e não tratadas com fungicida* \\
C & Sementes com Pyricularia oryzae e tratadas com fungicida* \\
D & Sementes sem Pyricularia oryzae e tratadas com fungicida* \\
\hline
\end{tabular}

* Pyroquilon $50 \mathrm{PM}$ na dose de $400 \mathrm{~g}$ do ingrediente ativo por $100 \mathrm{~kg}$ de sementes

\subsubsection{Segunda fase}

Essa fase inicia-se 10 dias antes do pleno florescimento da cultura até a maturação. Os tratamentos encontram-se na Tabela 4. 
Tabela 4. Descrição dos tratamentos referentes à segunda fase.

\begin{tabular}{|c|c|}
\hline Tratamento & Descrição \\
\hline$T_{1}(A)$ & $\begin{array}{l}\text { Sementes com Pyricularia oryzae, não tratadas com fungicida* e sem deficiência hídrica } \\
\text { durante todo o ciclo da cultura }\end{array}$ \\
\hline $\mathrm{T}_{2}(\mathrm{~A})$ & $\begin{array}{l}\text { Sementes com Pyricularia oryzae, não tratadas com fungicida* e com deficiência hídrica } \\
\text { durante } 10 \text { dias antes do pleno florescimento da cultura. }\end{array}$ \\
\hline $\mathrm{T}_{3}(\mathrm{~A})$ & $\begin{array}{l}\text { Sementes com Pyricularia oryzae, não tratadas com fungicida* e com deficiência hídrica } \\
\text { durante } 5 \text { dias antes do pleno florescimento da cultura }\end{array}$ \\
\hline $\mathrm{T}_{4}(\mathrm{~A})$ & $\begin{array}{l}\text { Sementes com Pyricularia oryzae, não tratadas com fungicida* e com deficiência hídrica } \\
\text { durante } 5 \text { dias após o pleno florescimento da cultura }\end{array}$ \\
\hline $\mathrm{T}_{5}(\mathrm{~B})$ & $\begin{array}{l}\text { Sementes sem Pyricularia oryzae, não tratadas com fungicida* e sem deficiência hidrica } \\
\text { durante todo o ciclo da cultura }\end{array}$ \\
\hline $\mathrm{T}_{6}(\mathrm{~B})$ & $\begin{array}{l}\text { Sementes sem Pyricularia oryzae, não tratadas com fungicida* e com deficiência hídrica } \\
\text { durante } 10 \text { dias antes do pleno florescimento da cultura }\end{array}$ \\
\hline$T_{7}(B)$ & $\begin{array}{l}\text { Sementes sem Pyricularia oryzae, não tratadas com fungicida* e com deficiência hídrica } \\
\text { durante } 5 \text { dias antes do pleno florescimento da cultura }\end{array}$ \\
\hline $\mathrm{T}_{8}(\mathrm{~B})$ & $\begin{array}{l}\text { Sementes sem Pyricularia oryzae, não tratadas com fungicida* e com deficiência hídrica } \\
\text { durante } 5 \text { dias depois do pleno florescimento da cultura }\end{array}$ \\
\hline $\mathrm{T}_{9}(\mathrm{C})$ & $\begin{array}{l}\text { Sementes com Pyricularia oryzae, tratadas com fungicida* e sem deficiência hídrica } \\
\text { durante todo o ciclo da cultura }\end{array}$ \\
\hline$T_{10}(C)$ & $\begin{array}{l}\text { Sementes com Pyricularia oryzae, tratadas com fungicida* e com deficiência hídrica } \\
\text { durante } 10 \text { dias antes do pleno florescimento da cultura }\end{array}$ \\
\hline $\mathrm{T}_{11}(\mathrm{C})$ & $\begin{array}{l}\text { Sementes com Pyricularia oryzae, tratadas com fungicida* e com deficiência hídrica } \\
\text { durante } 5 \text { dias antes do pleno florescimento da cultura }\end{array}$ \\
\hline$T_{12}(C)$ & $\begin{array}{l}\text { Sementes com Pyricularia oryzae, tratadas com fungicida* e com deficiência hídrica } \\
\text { durante } 5 \text { dias após o pleno florescimento da cultura }\end{array}$ \\
\hline$T_{13}(D)$ & $\begin{array}{l}\text { Sementes sem Pyricularia oryzae, tratadas com fungicida* e sem deficiência hídrica } \\
\text { durante todo o ciclo da cultura }\end{array}$ \\
\hline$T_{14}(D)$ & $\begin{array}{l}\text { Sementes sem Pyricularia oryzae, tratadas com fungicida* e com deficiência hídrica } \\
\text { durante } 10 \text { dias antes do pleno florescimento da cultura }\end{array}$ \\
\hline$T_{15}$ (D) & $\begin{array}{l}\text { Sementes sem Pyricularia oryzae, tratadas com fungicida* e com deficiência hídrica } \\
\text { durante } 5 \text { dias antes do pleno florescimento da cultura }\end{array}$ \\
\hline$T_{16}(D)$ & $\begin{array}{l}\text { Sementes sem Pyricularia oryzae, tratadas com fungicida* e com deficiência hídrica } \\
\text { durante } 5 \text { dias após o pleno florescimento da cultura }\end{array}$ \\
\hline
\end{tabular}

* Pyroquilon $50 \mathrm{PM}$, na dose de $400 \mathrm{~g}$ de ingrediente ativo por $100 \mathrm{~kg}$ de sementes 


\subsection{Caracterização do Substrato}

O substrato foi composto por duas partes de areia lavada de rio de granulação média, quatro partes de terra retirada do horizonte superficial de um solo classificado como Podzólico Vermelho-Amarelo textura argilosa, mantido em pousio durante três anos agrícolas, e anteriormente cultivado com milho, e uma parte de cama de frango humificada, e a homogeneização do substrato foi feita manualmente.

Uma amostra do substrato foi encaminhada para o Laboratório de Análises de Solos do Departamento de Ciências do Solos da Escola Superior de Agricultura "Luiz de Queiroz", da Universidade de São Paulo, em Piracicaba, Estado de São Paulo, e os resultados das análises química e física do substrato encontram-se na Tabela 5, Tabela $6 \mathrm{e}$ Tabela 7 .

Tabela 5. Resultado de análise química do substrato (macronutrientes).

\begin{tabular}{|c|c|c|c|c|c|c|c|c|c|c|c|c|}
\hline$\overline{\mathrm{pH}}$ & M.O. & $\underline{P}$ & $\mathrm{~S}-\mathrm{SO}_{4}$ & $\mathrm{~K}$ & $\mathrm{Ca}$ & $\mathrm{Mg}$ & $\mathrm{Al}$ & $\mathrm{H}+\mathrm{Al}$ & SB & $T$ & $\mathrm{~V}$ & $\mathrm{~m}$ \\
\hline $\mathrm{CaCl}_{2}$ & $\%$ & & $\mathrm{~cm}^{3}$ & \multicolumn{7}{|c|}{$\mathrm{meq} / 100 \mathrm{~cm}^{3}$} & \multicolumn{2}{|c|}{$\%$} \\
\hline 6,4 & 4,3 & 33 & 51,23 & 3,31 & 8,0 & 3,3 & 0,0 & 1,3 & 1,6 & 15,9 & 92 & $\overline{0}$ \\
\hline
\end{tabular}

Tabela 6. Resultado da análise química do substrato (micronutrientes).

\begin{tabular}{ccccccc}
\hline B & Cu & Fe & Mn & Zn & Na \\
& & & & & & \\
\hline 4,73 & 5,22 & 47 & & 47,68 & 7,7 & 55,2 \\
\hline
\end{tabular}


Tabela 7. Resultado de análise granulométrica do substrato (Método do Densímetro)

\begin{tabular}{|c|c|c|c|c|c|c|c|c|c|c|}
\hline \multicolumn{6}{|c|}{ Areia (\%) } & \multirow{2}{*}{$\begin{array}{c}\text { Silte } \\
\%\end{array}$} & \multicolumn{2}{|c|}{ Argila (\%) } & \multirow{2}{*}{$\begin{array}{c}\text { Floculação } \\
(\%)\end{array}$} & \multirow[t]{2}{*}{ Classe Textural } \\
\hline MG. $^{1}$ & $\mathrm{G}^{2}$ & $\mathrm{M}^{3}$ & $F^{4}$ & MF..$^{5}$ & Total & & Total & Água & & \\
\hline 2 & 7 & 20 & 39 & 5 & 73 & 8 & 19 & 10 & 47 & $\mathrm{md}-\mathrm{ar}^{6}$ \\
\hline
\end{tabular}

1 - areia muito grossa; 2 - areia grossa; 3 - areia média; 4 - areia fina; 5 - areia muito fina; 6 - média-arenosa

O substrato não sofreu tratamento fitossanitário e corretivo, mas nos 57 dias após a emergência da cultura foi efetuada aplicação líquida em todos os vasos $150 \mathrm{ppm}$ de $\mathrm{N}$ e 125 ppm de $\mathrm{K}$ na solução de $100 \mathrm{ml}$, utilizando como fontes uréia e cloreto de potássio, respectivamente.

\subsection{Preparo e arranjamento dos vasos}

Para se calcular a quantidade de substrato para enchimento dos vasos, determinouse o conteúdo de água do substrato através do método gravimétrico, utilizando a seguinte expressão:

$$
\mathrm{u}=\frac{\mathrm{m}_{\mathrm{u}}-\mathrm{m}_{\mathrm{s}}}{\mathrm{m}_{\mathrm{s}}}
$$

Onde u é o conteúdo de água ( $\left.\mathrm{g} \cdot \mathrm{g}^{-1}\right)$, a base de massa de solo seco, do substrato, $\mathrm{m}_{\mathrm{u}}$ é a massa ( $\mathrm{g}$ ) do solo úmido, e $\mathrm{m}_{\mathrm{s}}$ é a massa ( $\mathrm{g}$ ) do solo seco.

Foram colocadas numa estufa da marca Heraeus por 24 horas a $105^{\circ} \mathrm{C}$, quatro amostras do substrato de $100 \mathrm{~g}$ cada. Após 24 horas as amostras foram pesadas e apresentaram os seguintes resultados: $\mathrm{m}_{\mathrm{s}_{1}}=90,1 \mathrm{~g}, \mathrm{~m}_{\mathrm{s}_{2}}=91,2 \mathrm{~g}, \mathrm{~m}_{\mathrm{s}_{3}}=91,5 \mathrm{~g}$ e $\mathrm{m}_{\mathrm{s} 4}=91,1 \mathrm{~g}$

Utilizando-se a equação 1 , determinou-se o conteúdo de água do solo descrita anteriormente para cada uma da quatro amostras, e em seguida calculou-se a média aritmética dos valores obtidos $\left(\mathrm{u}=0,0991 \mathrm{~g} \cdot \mathrm{g}^{-1}\right)$. 
Foi atribuída a massa específica desejada para o substrato no vaso no valor de 1,2 g.cm $\mathrm{cm}^{-3}$.

Para a determinação da massa $\left(\mathrm{m}_{\mathrm{u}}, \mathrm{g}\right)$ de substrato úmido a ser colocada nos vasos foi utilizada a seguinte expressão:

$$
\mathrm{m}_{\mathrm{u}}=(\mathrm{u}+1) \mathrm{p}_{\mathrm{s}} \mathrm{V}
$$

Onde $\mathrm{V}$ é o volume $\left(\mathrm{cm}^{3}\right)$ do vaso, $\rho_{\mathrm{s}}$ a massa específica desejada $\left(\mathrm{g} . \mathrm{cm}^{-3}\right)$ do substrato e $\mathrm{u}$ o conteúdo de água do substrato a base de massa $\left(\mathrm{g} \cdot \mathrm{g}^{-1}\right)$, obtidas pelas seguintes expressões:

$$
\begin{aligned}
\rho_{s} & =\frac{m_{s}}{V} \\
u & =\frac{m_{a}}{m_{s}}
\end{aligned}
$$

Onde $\mathrm{m}_{\mathrm{S}}$ é a massa (g) do substrato seco, e $\mathrm{m}_{\mathrm{a}}$ é a massa ( $\mathrm{g}$ ) de água do substrato, sendo que:

$$
\mathrm{m}_{\mathrm{u}}=\mathrm{m}_{\mathrm{a}}+\mathrm{m}_{\mathrm{s}}
$$

O resultado obtido após a aplicação da fórmula foi de $13.200 \mathrm{~g}$ de substrato para cada vaso, sendo que durante o enchimento, os vasos eram periodicamente pesados com o auxílio de uma balança da marca Scarceli com capacidade de $20 \mathrm{~kg}$ e precisão de $20 \mathrm{~g}$, ’a fim de se manter a massa específica desejada.

Para calcular a capacidade de vaso, ou seja a quantidade máxima de água retida pelo substrato contido no vaso contra a ação da gravidade (drenagem livre), foram utilizados quatro vasos devidamente preenchidos com a quantidade determinada de substrato. Cada vaso foi colocado dentro de um balde cilíndrico de plástico transparente com capacidade de 20 litros, com graduação em litros. No fundo de cada balde foram colocados quatro calços de metal para que o vaso não entrasse em contato com o fundo do balde, permitindo entrada de água nos furos de drenagem do vaso. Em seguida foi acrescentada água no balde até que se atingisse um terço da altura do vaso. Após 24 horas 
foi acrescentada novamente água no balde até que se atingisse dois terços da altura do vaso. Decorridas novamente 24 horas foi completado o nivel de água do balde até que se atingisse a altura completa de cada vaso, sem que no entanto a água pudesse entrar em contato com a superfície do substrato contido no vaso.

Durante três dias a água foi sendo absorvida através dos furos existentes no fundo dos vasos pelo substrato. Com o movimento de ascensão da água durante o tempo decorrido o ar que preenchia os macro e microporos foi expulso, e ao final do terceiro dia o substrato atingiu o ponto de saturação máximo de água.

No quarto dia os vasos foram retirados dos baldes, colocados sobre bancadas teladas para que o excesso de água fosse drenado com a ação da força da gravidade. Uma hora após o início da drenagem não se observava mais nenhum excedente de água sendo drenado dos vasos.

Procedeu-se então a pesagem dos vasos numa balança da marca Scarceli com capacidade de $20 \mathrm{~kg}$ e precisão de $20 \mathrm{~g}$, onde foi calculada a média aritmética das massas dos quatro vasos pesados. A massa determinada na pesagem foi considerada como sendo a massa dos vasos em capacidade de vaso. A massa do vaso em capacidade de vaso foi de $16.760 \mathrm{~g}$ (massa do vaso vazio que foi de $490 \mathrm{~g}$, mais a massa do substrato que foi de $13.200 \mathrm{~g}$ mais $3.070 \mathrm{ml}$ de água ou $3.070 \mathrm{~g}$ de água).

Com o objetivo de selecionar os vasos mais homogêneos no tocante à massa em capacidade de vaso para que esses fossem marcados e conduzidos até o final do experimento, procedeu-se da seguinte forma: em nove bancadas teladas com 1,8 $\mathrm{m}$ de largura, $2,65 \mathrm{~m}$ de comprimento e $0,8 \mathrm{~m}$ de altura foram distribuídos, 144 vasos ou 16 vasos por bancada, com $25 \mathrm{~cm}$ de distância entre vasos de acordo com uma distribuição quadrática. Foi necessário adotar-se um número maior de vasos do que o necessário, pois muitos deles seriam destruídos durante o experimento visando a correção dos valores das massas iniciais dos vasos com o desenvolvimento das plantas de arroz, restando no final do experimento apenas 64 vasos. 
Foram colocados $3.200 \mathrm{ml}$ de água em todos os vasos, e se esperou uma hora para que ocorresse a drenagem do excedente de água, e após a drenagem completada, os vasos ficaram na capacidade de vaso, com massa aproximada de $16.760 \mathrm{~g}$.

Selecionaram-se 64 vasos, 4 vasos por tratamento total de 16 tratamentos, com a massa o mais próximo possível da massa padrão do vaso em capacidade de vaso que era $16.760 \mathrm{~g}$. Esses vasos foram marcados, pois iriam permanecer até o final do experimento, $\mathrm{e}$ seriam pesados periodicamente para cálculo da quantidade de água para irrigação para cada tratamento, adotou-se as novas massas individuais de cada vaso como sendo a massa do vaso em capacidade de vaso, e se distribuíram os vasos marcados aleatoriamente entre as nove bancadas na casa-de-vegetação em ambiente totalmente homogêneo no tocante a temperatura, umidade relativa do ar, incidência de vento e radiação solar.

Foram utilizados vasos cilíndricos de plástico rígido de coloração branca com capacidade para 10 litros. Os vasos possuíam as seguintes dimensões: $24 \mathrm{~cm}$ de diâmetro e $28 \mathrm{~cm}$ de altura.

Fez-se seis furos no fundo dos vasos para permitir a drenagem do excesso de água por ocasião das irrigações. Uma tela de náilon foi colocada no fundo dos vasos na sua parte interna para evitar que o substrato vazasse pelos furos de drenagem.

\subsection{Semeadura e desbaste das plantas}

A semeadura foi efetuada no dia 01/12/1996, distribuíndo-se oito sementes por vaso na profundidade de $3 \mathrm{~cm}$, a emergência deu-se cinco dias após a semeadura, dia 06/12/1996, e 15 dias após foi feito o desbaste, deixando apenas quatro plantas por vaso.

\subsection{Irrigação}

Em intervalos de dois dias todos os vasos marcados eram pesados e para o cálculo da quantidade de água a ser colocada em cada vaso era utilizada a seguinte fórmula: 


$$
\mathrm{V}_{\mathrm{A}}=16760-\mathrm{M}_{\mathrm{v}}
$$

Onde $\mathrm{V}_{\mathrm{A}}$ é o volume $\left(\mathrm{cm}^{3}\right)$ de água, $\mathrm{M}_{\mathrm{V}}$ é a massa $(\mathrm{g})$ do vaso, considerando a massa específica da água de $1 \mathrm{~g} / \mathrm{cm}^{3}$.

Após a pesagem de todos os vasos marcados e calculada a quantidade de água necessária para cada vaso, era obtida a média aritmética da quantidade de água por tratamento. A quantidade de água calculada por tratamento era colocada individualmente em cada um dos vasos do tratamento.

\subsection{Correção da massa original dos vasos e rodỉzio}

Com o desenvolvimento das plantas de arroz a massa original dos vasos modificou-se, sendo necessário a sua correção periodicamente. As pesagem de plantas para correção da massa do vaso em capacidade de vaso foram efetuadas três vezes durante o transcorrer do experimento. A primeira quando a cultura encontrava-se no estádio fenológico de cinco a seis colmos (08/01/96), a segunda quando a cultura encontrava-se no início de formação do primórdio floral (31/01/96), e a terceira e última quando a cultura encontrava-se no início da formação de grãos (28/02/96).

Foi escolhido aleatoriamente um vaso por tratamento, onde as plantas de arroz presentes eram cuidadosamente retiradas. $\mathrm{O}$ substrato aderido às raízes era lavado, e logo após era efetuada a pesagem das plantas em uma balança da marca Vicris, com capacidade máxima de carga de $6 \mathrm{~kg}$, e precisão de $5 \mathrm{~g}$. A massa úmida das plantas do vaso referente a cada tratamento era somado a massa de cada vaso marcado por tratamento. Esse valor era considerado para o cálculo da necessidade de água para as irrigações subsequentes.

A cada dois dias (época da pesagem dos vasos) os vasos de cada bancada eram movimentados no sentido anti-horário para que fosse possível uma alternância de posição. Essa movimentação permitia que cada vaso passasse em todas as posições possíveis nas bancadas, a fim de ser exposto às diferentes incidências de luz e vento da casa-devegetação. 


\subsection{Deficiência hídrica}

A deficiência hídrica foi provocada através da suspensão da irrigação dos vasos, em períodos de 10 e 5 dias antes do pleno florescimento do arroz e 5 dias após o pleno florescimento, que foi previsto através da observação periódica das plantas para se determinar o estádio de desenvolvimento do início da formação do primórdio floral. Quando se observou este estádio previu-se que o florescimento ocorreria 30 dias após, de acordo com o desenvolvimento normal das plantas de arroz do cultivar IAC-165. O pleno florescimento da cultura ocorreu no dia 18/02/96, 74 dias do ciclo.

Quando do final do período de deficiência hídrica, em 28/02/96, retornou-se a irrigação para todos os vasos, considerando para o cálculo do volume de água a ser utilizado a massa dos vasos do dia da última irrigação, antes do início do período de deficiência hídrica.

\subsection{Controle e monitoramento das condições ambientes da casa-de-vegetação}

A casa-de-vegetação onde foi conduzido o experimento contava com controle automatizado de temperatura. Para o monitoramento das condições ambientes foi utilizado um termohigrógrafo modelo TH 500 fabricado pela Rene Graf. A temperatura do ar foi mantida sempre ao redor de $25^{\circ} \mathrm{C}$, e a umidade relativa do ar ao redor de $70 \%$.

\subsection{Registro dos estádios fenológicos}

Durante o transcorrer do experimento registrou-se periodicamente $\mathrm{o}$ desenvolvimento das plantas e se utilizou para isso a escala $\mathrm{BBCH}$ (desenvolvida pelos seguintes institutos de pesquisa e empresas privadas européias: Biologische Bundesanstalt für Land und Forstwirtschaft (BBA), Bundessortenamt (BSA), Institut für Gemüse \& Zierpflanzenbau Gossbeeren/Erfurt e.V. (IGZ) e Industrie-verband Agrar (IVA), Ciba- 
Geigy Química S.A., BASF S.A., Bayer S.A. e AgrEvo S.A (Ciba-Geigy AG, 1994). Os estádios fenológicos de acordo com a escala BBCH estão descritos na Tabela 8.

Tabela 8. Descrição dos estádios fenológicos da cultura do arroz de sequeiro segundo a escala BBCH (Ciba-Geigy AG, 1994).

\begin{tabular}{cccl}
\hline Data & $\begin{array}{c}\text { Dias da } \\
\text { emergência }\end{array}$ & $\begin{array}{c}\text { Estádio } \\
\text { fenológico }\end{array}$ & \multicolumn{1}{c}{ Descrição do estádio fenológico } \\
\hline $06 / 12 / 95$ & 00 & 07 & Início da emergência \\
$07 / 12 / 95$ & 01 & 09 & Emergência da folha primária \\
$08 / 12 / 95$ & 02 & 10 & Ponta da primeira folha verdadeira visível \\
$11 / 12 / 95$ & 05 & 12 & Duas folhas abertas \\
$14 / 12 / 95$ & 08 & 13 & Três folhas abertas \\
$21 / 12 / 95$ & 15 & 21 & Início do perfilhamento, primeiro perfilho visível \\
$29 / 12 / 95$ & 23 & $23-24$ & Três a quatro colmos visíveis \\
$05 / 01 / 96$ & 30 & $24-25$ & Quatro a cinco colmos visíveis \\
$12 / 01 / 96$ & 37 & $25-26$ & Cinco a seis colmos visíveis \\
$25 / 01 / 96$ & 50 & 29 & Máximo número de colmos visíveis (seis a sete colmos) \\
$28 / 01 / 96$ & 53 & 30 & Início da formação do primórdio floral. \\
$30 / 01 / 96$ & 55 & 32 & Formação da panícula: panícula com 1 a 2 mm de comprimento \\
$02 / 02 / 96$ & 58 & 34 & Início da elongação dos entre nós \\
$08 / 02 / 96$ & 64 & 47 & Emissão da folha bandeira \\
$10 / 02 / 96$ & 66 & 51 & Início da emissão da panícula \\
$12 / 02 / 96$ & 68 & 53 & 30\% da panícula emergida \\
$14 / 02 / 96$ & 70 & 57 & $70 \%$ da panícula emergida \\
$15 / 02 / 96$ & 71 & 59 & Final da emergência da panícula \\
$16 / 02 / 96$ & 72 & 61 & Início do florescimento \\
$18 / 02 / 96$ & 74 & 65 & Pleno florescimento \\
$23 / 02 / 96$ & 79 & 69 & Final do florescimento \\
$26 / 02 / 96$ & 82 & 73 & Início da formação de grãos leitosos \\
$07 / 03 / 96$ & 92 & $83-87$ & Início da maturação dos grãos até grãos duros \\
$13 / 03 / 96$ & 105 & 92 & Maturação completa dos grãos, época de colheita \\
\hline
\end{tabular}

\subsection{Avaliações}

\subsubsection{Análise de sanidade de sementes após o tratamento químico das sementes com fungicidas}

Essa avaliação foi realizada logo após o tratamento químico das sementes com Pyroquilon. A análise foi feita no Laboratório de Patologia da ESALQ/USP. Para essa 
avaliação utilizou-se o Método do Papel de Filtro descrito nas Regras para Análise de Sementes (Ministério da Agricultura e Reforma Agrária, 1992).

\subsubsection{Emergência de plântulas}

Aos 7, 10 e 14 dias após a semeadura foram contadas as plântulas emergidas de cada vaso. Para esta avaliação foram utilizados seis vasos por tratamento, sendo que os mesmos sofreram três avaliações (quatro vasos marcados mais dois vasos do mesmo tratamento escolhidos ao acaso).

\subsubsection{Número de colmos}

As avaliações foram realizadas aos 30 e 55 dias após a emergência das plantas. Foram contados todos os colmos das quatro plantas de cada vaso.

\subsubsection{Altura de plantas}

As avaliações foram realizadas aos 30 e 55 dias após a emergência das plantas. Foi medida a altura de todos os colmos de todas as plantas, da base de cada perfilho até a inserção da última folha. A altura média dos colmos foi feita através da média aritmética da alturas.

\subsection{5 Índice de área foliar}

As avaliações foram realizadas aos 30,55 e 82 dias após a emergência das plantas. Foram avaliadas todas as folhas completamente desenvolvidas em todos os colmos.

Para a determinação do índice de área foliar médio mediu-se o comprimento e a maior largura de todas as folhas do vaso, e através da fórmula determinou-se a área foliar de cada folha: 


$$
\mathrm{AF}=\mathrm{k} \cdot \mathrm{C} \cdot \mathrm{L}
$$

onde $\mathrm{AF}$ refere-se à área foliar $\left(\mathrm{cm}^{2}\right), \mathrm{C}$ ao comprimento $(\mathrm{cm}), \mathrm{L}$ à largura $(\mathrm{cm})$, e k ao fator de forma de correção de área, utilizando o valor 0,75 (Pearce et al., 1975).

Em seguida foi feito uma somatória de todos as áreas foliares e a área foliar média do vaso foi obtida dividindo-se a somatória das áreas foliares do vaso pelo número de plantas do vaso.

Posteriormente calculou-se a área do vaso, cujo resultado foi de $452,39 \mathrm{~cm}^{2}$, e com base neste número foi possível calcular a área do vaso ocupada por uma planta de arroz, dividindo-se a área do vaso pelo número de plantas de arroz existente no vaso.

$\mathrm{O}$ Índice de área foliar (IAF) médio de uma planta, posteriormente foi determinado através da seguinte fórmula:

$$
\mathrm{IAF}=\frac{\mathrm{Af}_{\mathrm{m}}}{\mathrm{Av}}
$$

onde $\mathrm{Af}_{\mathrm{m}}$ refere-se à área foliar média de uma planta por vaso e $\mathrm{Av}$ à área do vaso ocupada por uma planta.

\subsubsection{Número de panículas}

Essa avaliação foi feita aos 108 dias após a emergência da cultura, na época da colheita, sendo contadas todas as panículas desenvolvidas.

\subsubsection{Massa de raízes secas, de parte aérea seca (colmos e folhas), e de panículas secas}

As plantas foram colhidas aos 108 dias após a emergências, sendo retiradas dos vasos com auxílio de jatos de água, e o sistema radicular das plantas separado do substrato completamente. Em seguida as plantas foram separadas em raízes, parte aérea (colmos e folhas) e panículas. 
As partes separadas foram pré-secadas na casa-de-vegetação por 48 horas, e após esse período colocados em estufa a $70^{\circ} \mathrm{C}$ por quatro dias até massa constante. Após a secagem foi feita a pesagem em balança de precisão da marca Mettler, modelo $\mathrm{K} 7$, com capacidade para $500 \mathrm{~g}$, e precisão de $0,1 \mathrm{~g}$.

\subsubsection{Massa de grãos cheios e chochos}

Após a determinação da massa das panículas secas, os grãos foram derriçados manualmente, a separação dos grãos cheios dos grãos chochos foi feita com o auxílio de um assoprador de sementes da marca L.A. Erickson Products, durante 30 segundo de operação, até a separação total dos grãos cheios e dos grãos chochos. Os grãos cheios e chochos foram pesados separadamente em balança da marca Mettler, modelo K 7, com capacidade para $500 \mathrm{~g}$, e precisão de $0,1 \mathrm{~g}$.

\subsubsection{Número de grãos cheios e número de grão chochos e porcentagem de grão cheios}

Foi feita a contagem após a separação e pesagem dos grãos, e obtida a porcentagem de grãos cheios foi determinada por vaso.

\subsection{Delineamento experimental}

\subsubsection{Experimento em laboratório (teste de sanidade de sementes tratadas)}

Utilizaram-se quatro tratamentos descritos na Tabela 3, as repetições foram quatro. Os seguintes patógenos foram avaliados, atribuindo-se uma porcentagem de sementes contaminadas para cada patógeno: Pyricularia oryzae, Phoma sp., Trichoconiella padwickii., Fusarium sp., Drechslera oryzae, Aspergillus spp., Penicillium spp., e Rhinchosporium oryzae.

O modelo matemático utilizado foi: 


$$
Y_{i j}=m+t_{i j}+e_{i j}
$$

onde $\mathrm{i}$ é o número de tratamentos $(\mathrm{i}=1,2,3,4)$, $\mathrm{j}$ é o número de repetições $(\mathrm{j}=1,2,3,4)$, $\mathrm{Y}_{\mathrm{ij}}$ é a observação referente a j-ésima repetição do i-ésimo tratamento, $\mathrm{m}$ é a média geral, $\mathrm{t}_{\mathrm{i}}$ é o efeito do i-ésimo tratamento, e e $\mathrm{ij}$ é o erro inerente à parcela $\mathrm{Y}_{\mathrm{ij}}$.

O esquema de análise de variância foi o seguinte:

Tabela 9. Esquema de análise de variância referentes a variável porcentagem de sementes portadoras de patógenos.

\begin{tabular}{lccc}
\hline \multicolumn{1}{c}{ Causa da Variação } & Graus de Liberdade & Quadrados Médios & $\mathrm{F}$ \\
\hline Tratamentos & $\mathrm{i}-1$ & $\mathrm{~V}_{1}$ & $\mathrm{~V}_{1} / \mathrm{V}_{2}$ \\
Resíduos & $\mathrm{i}(\mathrm{j}-1)$ & $\mathrm{V}_{2}$ & \\
\hline Total & $\mathrm{ij}-1$ & & \\
\hline
\end{tabular}

$\mathrm{j}=$ número de repetições

$\mathrm{i}=$ número de tratamentos

Para o detalhamento da análise da variância, quando o teste $\mathrm{F}$ detectou diferença significativa entre os tratamentos, foi feito utilizando-se o teste de Tukey, para comparação de médias duas a duas.

Dada a natureza dos dados, porcentagem de sementes contaminadas por patógeno, foi utilizada a transformação arcoseno $\sqrt{y / 100}$.

\subsubsection{Experimento em casa-de-vegetação}

$\mathrm{O}$ experimento constou de 2 fases. $\mathrm{Na}$ primeira fase foram utilizados quatro tratamentos descritos na Tabela 3. 
Para contagem de plantas emergidas foram colocados 6 vasos de cada tratamento, cada um com 8 sementes, e avaliadas as plantas emergidas aos 7, 10 e 14 dias.

No final do perfilhamento e no pré-florescimento foram medidas as variáveis índice de área foliar médio por vaso (IAF, $\mathrm{m}^{2} \cdot \mathrm{m}^{-2}$ ), altura de plantas em cada vaso (AP, $\mathrm{cm}$ ) e número de colmos por vaso (NC)

O delineamento estatístico utilizado foi o inteiramente ao acaso, com parcelas subdivididas dentro das épocas de avaliação:

$$
Y_{i j k}=m+t_{i}+E_{i j}+a_{k}+t_{i k}+e_{i j k}
$$

onde o índice i se refere ao número de ordem dos tratamentos na primeira fase (Tabela 3) (i $=\mathrm{A}, \mathrm{B}, \mathrm{C}$ e D), $\mathrm{j}$ ao número de ordem das repetições ( $\mathrm{j}=1,2,3,4,5 \mathrm{e} 6$ ), $\mathrm{k}$ ao número de ordem das épocas de avaliação $(\mathrm{k}=1$ e 2 para índice de área foliar por vaso, altura de plantas e número de colmos por vaso no final do perfilhamento e no pré-florescimento, respectivamente; e k = 1, 2 e 3 para número de plantas emergidas aos 7, 10 e 14 dias após a semeadura, respectivamente), $\mathrm{Y}_{\mathrm{ijk}}$ à observação referente à j-ésima repetição do i-ésimo tratamento na k-ésima época de avaliação; $\mathrm{m}$ à média geral (constante em todas as observações); $t_{i}$ ao efeito do i-ésimo tratamento; $E_{\mathrm{ij}}$ ao erro devido às parcelas experimentais, $a_{k}$ ao efeito da k-ésima época de avaliação; ta $a_{i k}$ ao efeito da interação do iésimo tratamento com a k-ésima época de avaliação; e e $\mathrm{e}_{\mathrm{ijk}}$ ao erro devido às subparcelas.

O esquema da análise da variância para este modelo está descrito na Tabela 10. 
Tabela 10. Esquema da análise da variância referente às variáveis índice de área foliar (IAF), altura de plantas (AP) e número de colmos (NC) (primeira fase).

\begin{tabular}{lccc}
\hline Causa da variação & Graus de Liberdade & Quadrado Médio & $\mathrm{F}$ \\
\hline Tratamentos & $\mathrm{i}-1$ & $\mathrm{~V}_{1}$ & $\mathrm{~V}_{1} / \mathrm{V}_{2}$ \\
Resíduo (a) & $\mathrm{i}(\mathrm{j}-1)$ & $\mathrm{V}_{2}$ & \\
\hline (Parcelas) & $(\mathrm{ij}-1)$ & & \\
Avaliações & $\mathrm{k}-1$ & $\mathrm{~V}_{3}$ & $\mathrm{~V}_{3} / \mathrm{V}_{5}$ \\
Tratamentos x Avaliações & $(\mathrm{i}-1)(\mathrm{k}-1)$ & $\mathrm{V}_{4}$ & $\mathrm{~V}_{4} / \mathrm{V}_{5}$ \\
Resíduo (b) & $\mathrm{i}(\mathrm{j}-1)(\mathrm{k}-1)$ & $\mathrm{V}_{5}$ & \\
\hline Total & $\mathrm{ijk}-1$ & & \\
\hline
\end{tabular}

$\mathrm{Na}$ segunda fase do experimento os 4 tratamentos iniciais foram transformados em 16 tratamentos, ou seja, cada um dos 4 lotes iniciais foram tratados sem deficiência hídrica, com deficiência hídrica 10 dias antes do pleno florescimento, com deficiência hídrica 5 dias antes do pleno florescimento e com deficiência hídrica 5 dias após o pleno florescimento, descritos na Tabela 4.

Nessa segunda fase foram medidas as variáveis: $i$. índice de área foliar médio por vaso (IAF), ii. número de colmos por vaso (NC), iii. número de panículas por vaso (NPAN), iv. massa de raízes secas por vaso (MRS, g/vaso), v. massa de parte aérea seca por vaso (MPAS, g/vaso), vi. massa de panículas secas por vaso (MPS, g/vaso), vii. massa de grãos cheios secos por vaso (MGCS, g/vaso), viii. massa de grãos chochos secos por vaso (MGCOS, g/vaso), ix. número de grãos cheios por vaso (NGC), x. número de grãos chochos por vaso (NGCO), e xi. porcentagem de grãos cheios por vaso (\% $\mathrm{GC})$.

Dessas variáveis, apenas a variável número de colmos por vaso (NC) foi medida em duas épocas: pré-florescimento e maturação, seguindo o modelo de análise inteiramente ao acaso com parcelas subdivididas pelas épocas de avaliações, modelo anterior.

As demais variáveis foram analisadas segundo o modelo inteiramente ao acaso: 


$$
Y_{i j}=m+t_{i}+e_{i j}
$$

onde o índice i se refere ao número de ordem dos tratamentos ( $i=T_{1}, T_{2}, T_{3}, T_{4}, T_{5}, T_{6}, T_{7}$, $T_{8}, T_{9}, T_{10}, T_{11}, T_{12}, T_{13}, T_{14}, T_{15}$, e $\left.T_{16}\right), j$ ao número de ordem das repetições $(j=1,2,3$, e 4), $\mathrm{Y}_{\mathrm{ij}}$ à observação referente à j-ésima repetição do i-ésimo tratamento, $\mathrm{m}$ à média geral, $\mathrm{t}_{\mathrm{i}}$ ao efeito do i-ésimo tratamento, $\mathrm{e}_{\mathrm{ij}}$ ao erro inerente à parcela referente à observação Yij, admitindo-se $e_{i j}$ apresenta distribuição normal com média 0 (zero) e variância $\mathrm{G}^{2}$.

O esquema de análise da variância para esse modelo está descrito na Tabela 11.

Tabela 11. Descrição do esquema de análise da variância referente às variáveis IAF (índice de área foliar), NPAN (número de panículas), MRS (massa de raízes secas), MPAS (massa de parte aérea seca), MPS (massa de panículas secas), MGCS (massa de grãos cheios secos), MGCOS (massa de grãos chochos secos), NGC (número de grãos cheios), NGCO (número de grãos chochos), e \% GC (porcentagem de grãos cheios).

\begin{tabular}{lccc}
\hline Causa da Variação & Graus de liberdade & Q.M. & $\mathrm{F}$ \\
\hline Tratamentos & $\mathrm{i}-1$ & $\mathrm{~V}_{1}$ & $\mathrm{~V}_{1} / \mathrm{V}_{2}$ \\
Resíduo & $\mathrm{i}(\mathrm{j}-1)$ & $\mathrm{V}_{2}$ & \\
\hline Total & $\mathrm{ij}-1$ & & \\
\hline
\end{tabular}

Para detalhamento da análise da variância, quando o teste $\mathrm{F}$ detectou diferença entre tratamentos, avaliações ou para a interação entre tratamentos versus avaliações foi utilizado o teste de Duncan para comparação de médias duas a duas.

Dado a estrutura de instalação da segunda fase do experimento, o detalhamento da análise da variância, quando o teste $\mathrm{F}$ detectou diferença significativa entre os tratamentos, foi feito o desdobramento dos graus de liberdade em contrastes ortogonais de interesse (Tabela 12). 
Tabela 12. Detalhamento da análise da variância, quando o teste $\mathrm{F}$ detectou diferença significativa entre os tratamentos, feito o desdobramento dos graus de liberdade em contrastes ortogonais de interesse.

\begin{tabular}{|c|c|}
\hline Contraste & Descrição \\
\hline $\mathrm{Y}_{1}$ & $\begin{array}{l}\text { Sementes com Pyricularia oryzae }\left(\mathrm{T}_{1} \text { a } \mathrm{T}_{4}\right) \text { versus sem Pyricularia oryzae }\left(\mathrm{T}_{5} \text { a } \mathrm{T}_{8} \text { e } \mathrm{T}_{13} \text { a } \mathrm{T}_{16}\right) \\
\text { (equação } 12 \text { ) }\end{array}$ \\
\hline $\mathrm{Y}_{2}$ & Sementes não tratadas $\left(T_{1}\right.$ a $\left.T_{4}\right)$ versus tratadas com Pyricularia oryzae $\left(T_{9}\right.$ a $\left.T_{12}\right)$ (equação 13) \\
\hline$Y_{3}$ & $\begin{array}{l}\text { Sementes não tratadas, com Pyricularia oryzae, sem deficiência hídrica }\left(\mathrm{T}_{1}\right) \text { versus com } \\
\left.\text { deficiência hídrica }\left(\mathrm{T}_{2} \mathrm{a}_{4}\right) \text { (equação } 14\right)\end{array}$ \\
\hline $\mathrm{Y}_{4}$. & $\begin{array}{l}\text { Sementes não tratadas, com Pyricularia oryzae e com deficiência hídrica antes }\left(T_{2} \text { e } T_{3}\right) \text { versus } \\
\left.\text { com deficiência hídrica após o pleno florescimento }\left(T_{4}\right) \text { (equação } 15\right)\end{array}$ \\
\hline$Y_{5}$ & $\begin{array}{l}\text { Sementes não tratadas, com Pyricularia oryzae e com deficiência hídrica } 5 \text { dias antes }\left(T_{2}\right) \text { versus } \\
\text { com deficiência hídrica } 10 \text { dias antes do pleno florescimento }\left(T_{3}\right) \text { (equação } 16 \text { ) }\end{array}$ \\
\hline $\mathrm{Y}_{6}$ & $\begin{array}{l}\text { Sementes tratadas, com Pyricularia oryzae, sem deficiência hídrica }\left(T_{9}\right) \text { versus com deficiência } \\
\text { hídrica }\left(\mathrm{T}_{10} \text { a } \mathrm{T}_{12}\right) \text { (equação } 17 \text { ) }\end{array}$ \\
\hline $\mathrm{Y}_{7}$ & $\begin{array}{l}\text { Sementes tratadas, com Pyricularia oryzae, com deficiência hídrica antes }\left(\mathrm{T}_{10} \text { e } \mathrm{T}_{11}\right) \text { versus com } \\
\text { deficiência hídrica após o pleno florescimento }\left(\mathrm{T}_{12}\right) \text { (equação } 18 \text { ) }\end{array}$ \\
\hline$Y_{8}$ & $\begin{array}{l}\text { Sementes tratadas, com Pyricularia oryzae, com deficiência hídrica } 5 \text { dias antes }\left(T_{10}\right) \text { versus com } \\
\text { deficiência hídrica } 10 \text { dias antes do pleno florescimento }\left(T_{11}\right) \text { (equação 19) }\end{array}$ \\
\hline$Y_{9}$ & Sementes não tratadas $\left(T_{5}\right.$ a $\left.T_{8}\right)$ versus tratadas, sem Pyricularia oryzae $\left(T_{13}\right.$ a $\left.T_{16}\right)$ (equação 20 ) \\
\hline$Y_{10}$ & $\begin{array}{l}\text { Sementes não tratadas, sem Pyricularia oryzae, sem deficiência hídrica }\left(\mathrm{T}_{5}\right) \text { versus com } \\
\left.\text { deficiência hídrica }\left(\mathrm{T}_{6} \text { a } \mathrm{T}_{8}\right) \text { (equação } 21\right)\end{array}$ \\
\hline$Y_{11}$ & $\begin{array}{l}\text { Sementes não tratadas, sem Pyricularia oryzae, com deficiência hídrica antes }\left(\mathrm{T}_{6} \text { e } \mathrm{T}_{7}\right) \text { versus com } \\
\left.\text { deficiência hídrica após o pleno florescimento }\left(\mathrm{T}_{8}\right) \text { (equação } 22\right)\end{array}$ \\
\hline $\mathrm{Y}_{12}$ & $\begin{array}{l}\text { Sementes não tratadas, sem Pyricularia oryzae, com deficiência hídrica } 5 \text { dias antes }\left(T_{6}\right) \text { versus } \\
\text { com deficiência hídrica } 10 \text { dias antes do pleno florescimento }\left(T_{12}\right) \text { (equação } 23 \text { ) }\end{array}$ \\
\hline $\mathrm{Y}_{13}$ & $\begin{array}{l}\text { Sementes tratadas, sem Pyricularia oryzae, sem deficiência hídrica }\left(T_{13}\right) \text { versus com deficiência } \\
\left.\text { hídrica }\left(\mathrm{T}_{14} \mathrm{a} \mathrm{T}_{16}\right) \text { (equação } 24\right)\end{array}$ \\
\hline$Y_{14}$ & $\begin{array}{l}\text { Sementes tratadas, sem Pyricularia oryzae, com deficiência hídrica antes }\left(T_{14} \text { e } T_{15}\right) \text { versus com } \\
\text { deficiência hídrica após o pleno florescimento }\left(T_{16}\right) \text { (equação } 25 \text { ) }\end{array}$ \\
\hline$Y_{15}$ & $\begin{array}{l}\text { Sementes tratadas, sem Pyricularia oryzae, com deficiência hídrica } 5 \text { dias antes }\left(T_{14}\right) \text { versus com } \\
\text { deficiência hidrica } 10 \text { dias antes do pleno florescimento }\left(T_{15}\right) \text { (equação } 26 \text { ) }\end{array}$ \\
\hline
\end{tabular}

$$
\mathrm{Y}_{1}=\left(\mathrm{T}_{1}+\mathrm{T}_{2}+\mathrm{T}_{3}+\mathrm{T}_{4}\right)-\mathrm{T}_{5}-\mathrm{T}_{6}-\mathrm{T}_{7}-\mathrm{T}_{8}+\left(\mathrm{T}_{9}+\mathrm{T}_{10}+\mathrm{T}_{11}+\mathrm{T}_{12}\right)-\mathrm{T}_{13}-\mathrm{T}_{14}-\mathrm{T}_{15}-\mathrm{T}_{16}
$$

$$
\mathrm{Y}_{2}=\left(\mathrm{T}_{1}+\mathrm{T}_{2}+\mathrm{T}_{3}+\mathrm{T}_{4}\right)-\mathrm{T}_{9}-\mathrm{T}_{10}-\mathrm{T}_{11}-\mathrm{T}_{12}
$$

$$
\mathrm{Y}_{3}=3\left(\mathrm{~T}_{1}\right)-\mathrm{T}_{2}-\mathrm{T}_{3}-\mathrm{T}_{4}
$$

$$
Y_{4}=\left(T_{2}+T_{3}\right)-2 T_{4}
$$




$$
\begin{gathered}
\mathrm{Y}_{5}=\left(\mathrm{T}_{2}\right)-\mathrm{T}_{3} \\
\mathrm{Y}_{6}=3\left(\mathrm{~T}_{9}\right)-\mathrm{T}_{10}-\mathrm{T}_{11}-\mathrm{T}_{12} \\
\mathrm{Y}_{7}=\left(\mathrm{T}_{10}+\mathrm{T}_{11}\right)-2 \mathrm{~T}_{12} \\
\mathrm{Y}_{8}=\left(\mathrm{T}_{10}\right)-\mathrm{T}_{11} \\
\mathrm{Y}_{9}=\left(\mathrm{T}_{5}+\mathrm{T}_{6}+\mathrm{T}_{7}+\mathrm{T}_{8}\right)-\mathrm{T}_{13}-\mathrm{T}_{14}-\mathrm{T}_{15}-\mathrm{T}_{16} \\
\mathrm{Y}_{10}=3\left(\mathrm{~T}_{5}\right)-\mathrm{T}_{6}-\mathrm{T}_{7}-\mathrm{T}_{8} \\
\mathrm{Y}_{11}=\left(\mathrm{T}_{6}+\mathrm{T}_{7}\right)-2 \mathrm{~T}_{8} \\
\mathrm{Y}_{12}=\left(\mathrm{T}_{6}\right)-\mathrm{T}_{7} \\
\mathrm{Y}_{13}=3\left(\mathrm{~T}_{13}\right)-\mathrm{T}_{14}-\mathrm{T}_{15}-\mathrm{T}_{16} \\
\mathrm{Y}_{14}=\left(\mathrm{T}_{14}+\mathrm{T}_{15}\right)-2 \mathrm{~T}_{16} \\
\mathrm{Y}_{15}=\left(\mathrm{T}_{14}\right)-\mathrm{T}_{15}
\end{gathered}
$$

Antes de se proceder a análise da variância, foi feita a análise exploratória dos dados utilizando-se as técnicas: i. diagrama de ramos e folhas para visualização da distribuição dos dados; ii. detecção de possíveis dados discrepantes; iii. teste de homogeneidade de variâncias; iv análise gráfica dos resíduos do modelo.

$O$ teste de homogeneidade de variâncias foi feito pelo teste de $F_{\max }$ :

$$
\mathrm{F}_{\max }=\frac{\mathrm{s}_{\max }^{2}}{\mathrm{~s}_{\min }^{2}} \approx \mathrm{F}(\mathrm{k}, \mathrm{v}, \alpha)
$$

onde $s_{\max }^{2}$ e $s_{\min }^{2}$ são a maior e a menor variância associada a tratamentos, respectivamente, $\mathrm{F}(\mathrm{k} ; \mathrm{v} ; \propto)$ é o valor tabelado da distribuição $\mathrm{F}$, com $\mathrm{k}$ tratamentos, $\mathrm{v}$ graus de liberdade de repetições e um nível $\propto$ de probabilidade. 
Através da análise dos resíduos, concluiu-se que os dados da variável número de plantas emergidas violava a pressuposição de independência para se efetuar a análise da variância.

Para as variáveis massa de grãos chochos secos por vaso (MGCOS) e número de grãos chochos por vaso (NGCO) foi detectada heterogeneidade do tipo regular e falta de normalidade, restabelecidas ambas pressuposições através da transformação raiz quadrada.

Para as demais variáveis, das duas fases do experimento, a análise exploratória não detectou nenhuma violação às pressuposições do modelo para análise da variância. 


\section{RESULTADOS E DISCUSSÃo}

\subsection{Experimento em laboratório (teste de sanidade de sementes tratadas)}

As análises de variância para os tratamentos encontram-se na Tabela 13 e Tabela 14.

Observa-se nas citadas tabelas, que foram detectadas diferenças significativas entre os tratamentos para a variável porcentagem de sementes portadoras de patógenos, para todos os patógenos avaliados.

Tabela 13. Análise de variância (quadrados médios) e teste $\mathrm{F}$, para a variável porcentagem de sementes portadoras de Pyricularia oryzae, Phoma sp., Trichoconiella padwickii, e Fusarium sp. (dados transformados em arcoseno $\sqrt{y / 100}$ ).

\begin{tabular}{lccccc}
\hline C. Variação & G.L. & $\begin{array}{c}\text { Pyricularia } \\
\text { oryzae }\end{array}$ & Phoma sp. & $\begin{array}{c}\text { Trichoconiella } \\
\text { padwickii }\end{array}$ & Furasium sp. \\
\hline Tratamentos & 3 & $989,4249^{* *}$ & $729,5008^{* *}$ & $927,6613^{* *}$ & $33,6475^{*}$ \\
Resíduo & 12 & 1,0795 & 0,8720 & 3,2244 & 6,7384 \\
\hline Total & 15 & & \\
\hline$*$ & significativo pelo teste $\mathrm{F}$, ao nível de 1\% de probabilidade. \\
$* *$ & significativo pelo teste $\mathrm{F}$, ao nível de 5\% de probabilidade.
\end{tabular}


Tabela 14. Análise de variância (quadrados médios) e teste $\mathrm{F}$, para a variável porcentagem de sementes portadoras de Drechslera oryzae, Aspergillus spp., Penicillium spp., e Rhinchosporium oryzae. (dados transformados em arcoseno $\sqrt{y / 100}$ ).

\begin{tabular}{|c|c|c|c|c|c|}
\hline C. Variação & $\overline{\text { G.L. }}$ & Drechslera oryzae & $\begin{array}{c}\text { Aspergillus } \\
\text { spp. }\end{array}$ & $\begin{array}{l}\text { Penicillium } \\
\text { spp. }\end{array}$ & Rhinchosporium oryzae \\
\hline Tratamentos & 3 & $611,2483^{* *}$ & $317,0920^{* *}$ & $66,2489^{* *}$ & $766,3158^{* *}$ \\
\hline Resíduo & 12 & 0,6476 & 0,2435 & 0,7535 & 1,1166 \\
\hline
\end{tabular}

Total 15

* significativo pelo teste $\mathrm{F}$, ao nivel de $1 \%$ de probabilidade.

** significativo pelo teste $\mathrm{F}$, ao nivel de $5 \%$ de probabilidade.

O detalhamento da análise de variância para tratamentos, através do teste de Tukey encontra-se na Tabela 15 e Tabela 16.

Tabela 15. Médias sem transformação e teste de Tukey para tratamentos, para a variável porcentagem de sementes portadoras de Pyricularia oryzae, Phoma sp., Trichoconiella padwickii, e Fusarium sp.

\begin{tabular}{ccccc}
\hline Tratamento & $\begin{array}{c}\text { Pyricularia } \\
\text { oryzae }\end{array}$ & Phoma sp. & $\begin{array}{c}\text { Trichoconiella } \\
\text { padwickii }\end{array}$ & Fusarium sp. \\
\hline $\mathrm{A}$ & $30 \mathrm{a}$ & $23 \mathrm{a}$ & $0 \mathrm{~b}$ & $2 \mathrm{ab}$ \\
$\mathrm{B}$ & $2 \mathrm{~b}$ & $3 \mathrm{~b}$ & $27 \mathrm{a}$ & $3 \mathrm{a}$ \\
$\mathrm{C}$ & $0 \mathrm{c}$ & $0 \mathrm{c}$ & $0 \mathrm{~b}$ & $0,5 \mathrm{~b}$ \\
$\mathrm{D}$ & $0 \mathrm{c}$ & $0 \mathrm{c}$ & $0,5 \mathrm{~b}$ & $1,75 \mathrm{ab}$
\end{tabular}

Média seguidas de letras iguais, nas colunas, não diferem entre si ao nivel de $5 \%$ de probabilidade. 
Tabela 16. Médias não transformadas e teste de Tukey para tratamentos, para a variável porcentagem de sementes portadoras de Drechslera oryzae, Aspergillus spp., Penicillium spp., e Rhinchosporium oryzae.

\begin{tabular}{ccccc} 
Tratamento & Drechslera oryzae & Aspergillus spp. & Penicillium spp. & $\begin{array}{c}\text { Rhinchosporium } \\
\text { oryzae }\end{array}$ \\
\hline A & $5 \mathrm{~b}$ & $14 \mathrm{a}$ & $2 \mathrm{a}$ & $0 \mathrm{c}$ \\
B & $19 \mathrm{a}$ & $1 \mathrm{c}$ & $1 \mathrm{~b}$ & $24 \mathrm{a}$ \\
C & $0 \mathrm{c}$ & $12 \mathrm{~b}$ & $0 \mathrm{c}$ & $0 \mathrm{c}$ \\
D & $0 \mathrm{c}$ & $1 \mathrm{c}$ & $0 \mathrm{c}$ & $3,75 \mathrm{~b}$ \\
\hline
\end{tabular}

Média seguidas de letras iguais, nas colunas, não diferem entre si ao nível de $5 \%$ de probabilidade

Observa-se que a contaminação em sementes com o tratamento $\mathrm{C}$ foi menor em todos os fungos, exceção feita a Aspergillus spp., onde o tratamento $\mathrm{C}$ apresentou a segunda maior contaminação.

A segunda menor contaminação por todos os patógenos ocorreu em sementes com o tratamento D, exceção feita a Rhinchosporium oryzae, onde o tratamento D apresentou a segunda maior contaminação.

Os tratamentos A e B apresentaram as maiores porcentagens de contaminação alternadamente, ou seja: o tratamento $\mathrm{A}$ apresentou maior média de porcentagem de contaminação das sementes para Pyricularia oryzae, Phoma sp., Aspergillus spp. e Penicillium spp., enquanto o tratamento $\mathrm{B}$ apresentou maior média de porcentagem de contaminação para Trichoconiella padwickii, Fusarium sp., Drechslera oryzae e Rhinchosporium oryzae.

As sementes tratadas apresentaram respostas, na maioria das vezes, no tocante a porcentagem de contaminação por patógenos, significativamente diferente das respostas obtidas com sementes não tratadas. 
O fungicida Pyroquilon controlou eficazmente todos os patógenos presentes nas sementes com exceção de Aspergillus spp. e Fusarium sp., resultados de acordo com o perfil biológico do produto (Ciba-Geigy Química S.A., 1990).

\subsection{Experimento em casa-de-vegetação}

\subsubsection{Número de plantas emergidas (primeira fase)}

Para a variável número de plantas emergidas foi realizada apenas a análise descritiva, pois uma análise exploratória dos dados detectou heterogeneidade da variância das médias irregular, uma provável causa foi o pequeno número de sementes por vaso. Os resultados encontram-se descritos na Tabela 17.

Tabela 17. Descrição do número de plantas emergidas por tratamento (primeira fase)

Número de plantas emergidas (média de seis repetições)

\begin{tabular}{cccc}
\hline Tratamento & 7 dias após semeadura & 10 dias após semeadura & 14 dias após semeadura \\
\hline A & 5,17 & 6,00 & 6,17 \\
B & 6,67 & 7,17 & 7,50 \\
C & 5,83 & 6,50 & 6,83 \\
D & 7,33 & 7,83 & 8,00 \\
\hline
\end{tabular}

\subsection{2 Índice de área foliar, altura de plantas e número de colmos (primeira fase)}

Observa-se, pela Tabela 18, que foram detectadas diferenças significativas entre tratamentos para as variáveis AP (altura de plantas) e NC (número de colmos), não 
ocorrendo diferenças significativas entre os tratamentos para a variável IAF (índice de área foliar).

Já entre as duas avaliações foram detectadas diferenças significativas para as variáveis IAF (índice de área foliar) e AP (altura de plantas), não ocorrendo diferenças significativas para NC (número de colmos).

Quanto a interação Tratamentos versus Avaliações, só foi evidenciada diferença significativa para a variável AP (altura de plantas).

Resumindo, as variações na variável IAF (índice de área foliar) são devidas apenas às épocas de avaliações, na variável NC (número de colmos) apenas aos tratamentos e na variável AP (altura de plantas) à combinação (interação) de tratamentos com épocas de avaliações.

Tabela 18. Análise da variância (Quadrados médios) e teste $\mathrm{F}$ para as variáveis. Índice de área foliar (IAF), altura de plantas em $\mathrm{cm}$ (AP) e número de colmos (NC), (primeira fase).

\begin{tabular}{lcccc}
\hline $\begin{array}{l}\text { Causa da } \\
\text { Variação }\end{array}$ & $\begin{array}{c}\text { Graus de } \\
\text { Liberdade }\end{array}$ & IAF & AP & NC \\
\hline Tratamentos & 3 & $0,62830^{\text {ns }}$ & $26,98537^{* *}$ & $31,58333^{* *}$ \\
Resíduo (A) & 20 & 0,34212 & 1,85840 & 4,57500 \\
\hline (Parcelas) & $(23)$ & & & \\
Avaliações & 1 & $216,19785^{* *}$ & $1341,75598^{* *}$ & $16,33333^{\text {ns }}$ \\
Trat. x Aval. & 3 & $0,03390^{\text {ns }}$ & $20,29625^{* *}$ & $0,16667^{\text {ns }}$ \\
Resíduo (B) & 20 & 0,21107 & 1,41463 & 5,40833 \\
\hline Total & 47 & & & \\
\hline
\end{tabular}

** Significativo pelo teste $\mathrm{F}$, ao nível de $1 \%$ de probabilidade.

ns Não significativo pelo teste $F$, considerando-se um nível mínimo de significância (n.m.s) de 5\%. 
O detalhamento da análise da variância para tratamentos, para épocas de avaliações, e para tratamentos dentro de épocas de avaliações, pelo teste de Duncan, está descrito na Tabela 18.

Tabela 19. Médias sem transformação e teste de Duncan, para as variáveis IAF (índice de área foliar), $\mathrm{AP}$ (altura de plantas em $\mathrm{cm}$ ) e $\mathrm{NC}$ (número de colmos), (primeira fase).

\begin{tabular}{cccc}
\hline Tratamentos & IAF & AP & NC \\
\hline A & $4,08 \mathrm{~b}$ & $20,68 \mathrm{~b}$ & $18,92 \mathrm{a}$ \\
B & $4,23 \mathrm{ab}$ & $23,69 \mathrm{a}$ & $15,92 \mathrm{~b}$ \\
$\mathrm{C}$ & $4,31 \mathrm{ab}$ & $21,58 \mathrm{~b}$ & $19,67 \mathrm{a}$ \\
D & $4,62 \mathrm{a}$ & $24,02 \mathrm{a}$ & $18,00 \mathrm{a}$
\end{tabular}

Médias seguidas de letras iguais, nas colunas, não diferem entre si ao nível de $5 \%$ de probabilidade.

Observa-se pela Tabela 19, que embora a análise de variância não tenha detectado diferença entre os tratamentos, para a variável IAF (índice de área foliar) foi evidenciado um contraste de médias significativo pelo teste de Duncan, entre o tratamento A (sementes com Pyricularia oryzae) e o D (sementes tratadas sem Pyricularia oryzae), ao nível de 5\% de probabilidade. No entanto, os resultados demonstraram que o fungicida Pyroquilon não promoveu nenhuma influência significativa, de aumento ou diminuição, da variável IAF (índice de área foliar) entre os tratamentos. Este é um dado inédito, pois não se pode encontrar em literatura qualquer referência a esse efeito fitoestimulante do Pyroquilon.

Para a variável AP (altura de plantas), observa-se que se formaram dois pares de médias separadas. As médias de $\mathrm{A}$ e $\mathrm{C}$ são iguais entre si (respectivamente, sementes não tratadas e tratada com Pyricularia oryzae), e significativamente inferiores, pelo teste de Duncan, às médias de $\mathrm{B}$ e $\mathrm{D}$ (respectivamente sementes não tratadas e tratada sem Pyricularia oryzae), que também não diferiram estatisticamente entre si (embora a média de $D$, tratada, seja maior). Novamente o Pyroquilon não demonstrou nenhum efeito 
fitoestimulante entre os tratamentos, a diferença significativa entre o grupo de tratamento $\mathrm{A}$ e C contra B e D, deveu-se possivelmente a diferença de vigor entre os dois lotes de sementes utilizados, pois o lote que originou os tratamentos $\mathrm{A}$ e $\mathrm{C}$ demonstrou, na análise de qualidade de sementes realizada, ser menos vigoroso que o lote que originou os tratamentos B e D.

Para a variável NC (número de colmos por vaso) só foi detectada diferença significativa entre a média de B (sementes não tratadas sem Pyricularia oryzae) e a média dos demais tratamentos, sendo que $\mathrm{B}$ apresentou a menor média. O Pyroquilon não promoveu nenhum efeito fitoestimulante sobre esta variável, todos os tratamentos não apresentaram diferenças significativas, exceto o tratamento $B$, que apresentou a menor média devido a algum fator imponderado.

\subsection{3 Índice de área foliar e número de panículas (segunda fase)}

Observa-se, pela Tabela 20, que houve efeito significativo para tratamentos tanto para a variável IAF (a 1\% de probabilidade), como para a variável NPAN (número de panículas) (a $5 \%$ de probabilidade).

Tabela 20. Análise da variância (quadrados médios) e teste $F$ para as variáveis índice de área foliar (IAF) e número de panículas (NPAN), (segunda fase).

\begin{tabular}{lccc}
\hline Causa da variação & Graus de Liberdade & IAF & NPAN \\
\hline Tratamentos & 15 & $1,29151^{* *}$ & $16,80000^{*}$ \\
Resíduo & 48 & 0,40491 & 9,14583 \\
Total & 65 & & \\
\hline
\end{tabular}

* Significativo pelo teste $\mathrm{F}$, ao nível de $5 \%$ de probabilidade.

** Significativo pelo teste $\mathrm{F}$, ao nível de $1 \%$ de probabilidade.

$\mathrm{O}$ detalhamento da análise da variância, através do desdobramento dos graus de liberdade em contrastes ortogonais pelo teste $\mathrm{F}$, estabelecidos na instalação do experimento, apresentou o seguinte resultado, descrito na Tabela 21. 
Tabela 21. Desdobramento dos graus de liberdade de tratamentos (quadrados médios) em contrastes ortogonais, e teste $\mathrm{F}$, para as variáveis IAF (índice de área foliar) e NPAN (número de panículas), (segunda fase).

\begin{tabular}{cccc}
\hline C. Variação & G.L. & IAF & NPAN \\
\hline$Y_{1}$ & 1 & $4,07535^{\text {** }}$ & $1,00000^{\text {ns }}$ \\
$Y_{2}$ & 1 & $0,65551^{\text {ns }}$ & $10,12500^{\text {ns }}$ \\
$Y_{3}$ & 1 & $3,05021^{* *}$ & $35,02083^{*}$ \\
$Y_{4}$ & 1 & $0,90870^{\text {ns }}$ & $22,04167^{\text {ns }}$ \\
$Y_{5}$ & 1 & $0,14311^{\text {ns }}$ & $28,12500^{\text {ns }}$ \\
$Y_{6}$ & 1 & $3,22406^{* *}$ & $1,02083^{\text {ns }}$ \\
$Y_{7}$ & 1 & $0,88167^{\text {ns }}$ & $7,04167^{\text {ns }}$ \\
$Y_{8}$ & 1 & $0,16245^{\text {ns }}$ & $45,12500^{*}$ \\
$Y_{9}$ & 1 & $3,23215^{* *}$ & $28,12500^{\text {ns }}$ \\
$Y_{10}$ & 1 & $0,04380^{\text {ns }}$ & $20,02083^{\text {ns }}$ \\
$Y_{11}$ & 1 & $0,00167^{\text {ns }}$ & $32,66667^{\text {ns }}$ \\
$Y_{12}$ & 1 & $0,35280^{\text {ns }}$ & $0,00000^{\text {ns }}$ \\
$Y_{13}$ & 1 & $2,32320^{*}$ & $9,18750^{\text {ns }}$ \\
$Y_{14}$ & 1 & $0,02160^{\text {ns }}$ & $0,0000^{\text {ns }}$ \\
$Y_{15}$ & 1 & $0,29645^{\text {ns }}$ & $12,50000^{\text {ns }}$ \\
Resíduo & 48 & 0,40491 & 9,14583
\end{tabular}

Total 63

* Significativo pelo teste $\mathrm{F}$, ao nível de $5 \%$ de probabilidade.

** Significativo pelo teste $\mathrm{F}$, ao nível de $1 \%$ de probabilidade.

ns Não significativo pelo teste $F$, considerando-se um nível mínimo de significância (n.m.s.) de 5\%.

Observa-se que, para a variável IAF (índice de área foliar) foram significativos, ao nivel de $1 \%$ de probabilidade, os contrastes $\mathrm{Y}_{1}$ (sementes com Pyricularia oryzae versus sem Pyricularia oryzae), Y3 (sementes não tratadas, com Pyricularia oryzae, sem deficiência hídrica versus com deficiência hídrica), Y6 (sementes tratadas, com Pyricularia oryzae, sem deficiência hídrica versus com deficiência hídrica), Y9 (sementes não tratadas versus tratadas, sem Pyricularia oryzae) e, ao nível de 5\% de probabilidade, $\mathrm{Y}_{13}$ (sementes tratadas, sem Pyricularia oryzae, sem deficiência hídrica versus com deficiência hídrica). As estimativas desses contrastes e seus indicativos estão descritos na Tabela 22. 
Tabela 22. Descrição das estimativas dos contrastes relativos ao indice de área foliar (IAF) e seus indicativos.

\begin{tabular}{|c|c|c|}
\hline Contraste & $\begin{array}{c}\text { Valor } \\
\text { estimado }\end{array}$ & Descrição \\
\hline$\overline{Y_{1}}$ & $+4,04$ & $\begin{array}{l}\text { As médias das sementes com Pyricularia oryzae superaram as sem } \\
\text { Pyricularia oryzae (equação 12) }\end{array}$ \\
\hline$Y_{3}$ & $+3,03$ & $\begin{array}{l}\text { As médias das sementes com Pyricularia oryzae e sem deficiência hídrica } \\
\text { superaram as sementes com Pyricularia oryzae e com deficiência hídrica } \\
\text { (equação 14) }\end{array}$ \\
\hline$Y_{6}$ & $+3,11$ & $\begin{array}{l}\text { As médias das sementes com Pyricularia oryzae, tratadas e sem } \\
\text { deficiência hídrica superaram as sementes tratadas, com Pyricularia } \\
\text { oryzae e com deficiência hídrica (equação 17) }\end{array}$ \\
\hline$Y_{9}$ & $-2,54$ & $\begin{array}{l}\text { As médias das sementes sem Pyricularia oryzae, tratadas superaram as } \\
\text { sementes não tratadas, sem Pyricularia oryzae (equação } 20 \text { ) }\end{array}$ \\
\hline$Y_{13}$ & $+2,64$ & $\begin{array}{l}\text { As média das sementes sem Pyricularia oryzae, tratadas e sem deficiência } \\
\text { hídrica superaram as sementes tratadas, sem Pyricularia oryzae e com } \\
\text { deficiência hídrica (equação } 24 \text { ) }\end{array}$ \\
\hline
\end{tabular}

Os tratamentos com sementes com Pyricularia oryzae não sofreram nenhuma influência deste patógeno que levasse à uma diminuição do IAF (índice de área foliar) quando comparado aos tratamentos com sementes sem Pyricularia oryzae. Isso evidenciou que o fungo em questão não encontrou condições ambientes propícias para o seu desenvolvimento, que pudesse causar danos nas plantas oriundas de sementes contaminadas.

Os tratamentos com sementes tratadas sem Pyricularia oryzae foram superiores aos tratamentos com sementes não tratadas sem Pyricularia oryzae, neste caso evidenciando o efeito fitoestimulante do Pyroquilon sobre o IAF (índice de área foliar) nesta fase do experimento, ou podemos inferir até mesmo um efeito residual que se iniciou logo após a emergência da cultura e que se extendeu até o início de maturação dos grãos, época da avaliação. Esse efeito residual do produto controla Pyricularia oryzae nas folhas do arroz até 60 dias após a emergência da cultura (Ciba-Geigy Química S.A., 1990), podendo influenciar no desenvolvimento da mesma além do período de controle.

Os tratamentos onde ocorreu deficiência hídrica foram inferiores aos tratamentos onde não ocorreu deficiência hídrica quando se avaliou a variável IAF (índice de área 
foliar). Essa diminuição do IAF (índice de área foliar) nos tratamentos com deficiência hídrica foi devido à diminuição da atividade fisiológica da planta de arroz quando submetida à períodos de deficiência hídrica, este comportamento já foi comentado por $\mathrm{Ma}$ $\& \mathrm{Lu}(1990)$

Para a variável NPAN (número de panículas) foram significativas, ao nível de $1 \%$ de probabilidade, apenas os contrastes $\mathrm{Y}_{3}$ (sementes não tratadas, com Pyricularia oryzae, sem deficiência hídrica versus com deficiência hídrica) e $\mathrm{Y}_{8}$ (sementes tratada, com Pyricularia oryzae, com deficiência hídrica 5 dias antes pleno florescimento versus 10 dias antes do pleno florescimento). As estimativas desses contrastes e seus indicativos estão descritos na Tabela 23.

Tabela 23. Descrição das estimativas dos contrastes relativos ao número de panículas e seus indicativos.

\begin{tabular}{|c|c|c|}
\hline Contraste & Valor estimado & Descrição \\
\hline $\mathrm{Y}_{3}$ & $-10,25$ & $\begin{array}{l}\text { As médias das sementes com Pyricularia oryzae, não tratadas e } \\
\text { com deficiência hídrica superaram as sementes não tratadas com } \\
\text { Pyricularia oryzae e sem deficiência hídrica (equação 14) }\end{array}$ \\
\hline$Y_{8}$ & $+4,75$ & $\begin{array}{l}\text { As médias das sementes com Pyricularia oryzae, tratada e com } \\
\text { deficiência hídrica } 10 \text { dias antes superaram as sementes tratadas } \\
\text { com Pyricularia oryzae e com deficiência hídrica } 5 \text { dias antes do } \\
\text { pleno florescimento (equação 19) }\end{array}$ \\
\hline
\end{tabular}

Nota-se que os quase todos tratamentos com deficiência hídrica foram superiores aos tratamentos sem deficiência hídrica no tocante à variável NPAN (número de panículas). Pereira et al. (1994) comenta que a deficiência hídrica promove alterações na morfologia e fisiologia das plantas. Quando da ocorrência de deficiência hídrica as plantas de arroz apresentam entre outros sintomas uma redução do perfilhamento, segundo Fageria (1984) e Fornasieri Filho \& Fornasieri (1993), os resultados obtidos são antagônicos mas explicáveis, pois a deficiência hídrica foi suspensa após os períodos preestabelecidas, e as plantas de arroz responderam o reinício das irrigação com uma nova emissão de colmos, provavelmente para compensar o atraso que a deficiência hídrica provocou no 
desenvolvimento normal da cultura, essa nova emissão de colmos provocou um maior número de panículas nos tratamento com deficiência hídrica.

Observa-se na Tabela 24, com certa sistematização, que os sinais dos contrastes foram opostos para essas duas variáveis, indicando, para os casos em que houve significância, que o melhor tratamento (ou grupo) para IAF (índice de área foliar) seria o pior para NPAN (número de panículas), e vice-versa.

Tabela 24. Descrição das estimativas dos contrastes para o grupo de variáveis IAF (índice de área foliar) e NPAN (número de panículas), (segunda fase).

\begin{tabular}{cccccc}
\hline Contrastes & IAF & NPAN & Contrastes & IAF & NPAN \\
\hline $\mathrm{Y}_{1}$ & $+4,04^{\text {** }}$ & $+2,00^{\text {ns }}$ & $\mathrm{Y}_{9}$ & $-2,54^{* *}$ & $+7,50^{\text {ns }}$ \\
$\mathrm{Y}_{2}$ & $-1,15^{\text {ns }}$ & $+4,50^{\text {ns }}$ & $\mathrm{Y}_{10}$ & $+0,36^{\text {ns }}$ & $-7,75^{\text {ns }}$ \\
$\mathrm{Y}_{3}$ & $+3,03^{* *}$ & $-10,25^{*}$ & $\mathrm{Y}_{11}$ & $+0,05^{\text {ns }}$ & $+7,00^{\text {ns }}$ \\
$\mathrm{Y}_{4}$ & $+1,17^{\text {ns }}$ & $+5,75^{\text {ns }}$ & $\mathrm{Y}_{12}$ & $-0,42^{\text {ns }}$ & $0,00^{\text {ns }}$ \\
$\mathrm{Y}_{5}$ & $-0,27^{\text {ns }}$ & $+3,75^{\text {ns }}$ & $\mathrm{Y}_{13}$ & $+2,64^{*}$ & $-5,25^{\text {ns }}$ \\
$\mathrm{Y}_{6}$ & $+3,11^{* *}$ & $-1,75^{\text {ns }}$ & $\mathrm{Y}_{14}$ & $-0,18^{\text {ns }}$ & $0,00^{\text {ns }}$ \\
$\mathrm{Y}_{7}$ & $+1,15^{\text {ns }}$ & $+3,25^{\text {ns }}$ & $\mathrm{Y}_{15}$ & $-0,39^{\text {ns }}$ & $+2,50^{\text {ns }}$ \\
$\mathrm{Y}_{8}$ & $-0,29^{\text {ns }}$ & $+4,75^{*}$ & & & \\
\hline
\end{tabular}

* Significativo pelo teste $\mathrm{F}$, ao nível de $5 \%$ de probabilidade.

** Significativo pelo teste $\mathrm{F}$, ao nível de $1 \%$ de probabilidade.

ns Não significativo pelo teste F, considerando-se um nível mínimo de significância (n.m.s) de $5 \%$.

Esse antagonismo sistemático é devido somente à ocorrência da deficiência hídrica. Os tratamentos que não sofreram deficiência hídrica apresentaram IAF (índice de área foliar) superiores aos tratamentos com deficiência hídrica, com relação ao NPAN (número de panículas) o comportamento foi exatamente o inverso.

O detalhamento da análise através de contrastes das médias duas a duas, pelo teste de Duncan, está apresentado na Tabela 25. 
Tabela 25. Médias sem transformação e teste de Duncan para tratamentos, para as variáveis índice de área foliar médio (IAF) e número de panículas (NPAN), (segunda fase).

\begin{tabular}{clllllll}
\hline Tratamento & \multicolumn{1}{c}{ LAF } & \multicolumn{2}{c}{ NPAN } & Tratamento & IAF & NPAN \\
\hline $\mathrm{T}_{1}$ & 6,44 & $\mathrm{ab}$ & $16,75 \mathrm{~b}$ & $\mathrm{~T}_{9}$ & $6,74 \mathrm{a}$ & $17,75 \mathrm{~b}$ \\
$\mathrm{~T}_{2}$ & 5,49 bcde & $23,00 \mathrm{a}$ & $\mathrm{T}_{10}$ & 5,76 abcde & $21,25 \mathrm{ab}$ \\
$\mathrm{T}_{3}$ & 5,76 abcde & $19,25 \mathrm{ab}$ & $\mathrm{T}_{11}$ & 6,04 abcd & $16,50 \mathrm{~b}$ \\
$\mathrm{~T}_{4}$ & $5,04 \mathrm{de}$ & $18,25 \mathrm{ab}$ & $\mathrm{T}_{12}$ & $5,32 \mathrm{cde}$ & $17,25 \mathrm{~b}$ \\
$\mathrm{~T}_{5}$ & $5,09 \mathrm{de}$ & $17,50 \mathrm{~b}$ & $\mathrm{~T}_{13}$ & $6,30 \mathrm{abc}$ & 16,25 & $\mathrm{~b}$ \\
$\mathrm{~T}_{6}$ & $4,77 \mathrm{e}$ & $21,25 \mathrm{ab}$ & $\mathrm{T}_{14}$ & $5,19 \mathrm{de}$ & $19,25 \mathrm{ab}$ \\
$\mathrm{T}_{7}$ & $5,19 \mathrm{de}$ & $21,25 \mathrm{ab}$ & $\mathrm{T}_{15}$ & $5,58 \mathrm{bcde}$ & $16,75 \mathrm{~b}$ \\
$\mathrm{~T}_{8}$ & $4,95 \mathrm{e}$ & $17,75 \mathrm{~b}$ & $\mathrm{~T}_{16}$ & 5,47 dcde & $18,00 \mathrm{~b}$ \\
\hline
\end{tabular}

Médias seguidas de letras iguais, nas colunas, não diferem entre si ao nível de $5 \%$ de probabilidade.

Observa-se, pela Tabela 25, que a maior média observada para IAF (índice de área foliar) foi a do T9 (sementes tratadas, com Pyricularia oryzae e sem deficiência hídrica), que diferiu significativamente de $\mathrm{T}_{2}, \mathrm{~T}_{4}$ (sementes não tratadas, com Pyricularia oryzae), $\mathrm{T}_{5}, \mathrm{~T}_{6}, \mathrm{~T}_{7}, \mathrm{~T}_{8}$ (sementes não tratadas, sem Pyricularia oryzae), $\mathrm{T}_{12}$ (sementes tratadas, com Pyricularia oryzae), $\mathrm{T}_{14}, \mathrm{~T}_{15}$ e $\mathrm{T}_{16}$ (sementes tratadas, sem Pyricularia oryzae), e a menor média observada foi a do $\mathrm{T}_{6}$ (sementes não tratadas, sem Pyricularia oryzae, com deficiência hídrica 10 dias antes do pleno florescimento) seguida do T8 (sementes não tratadas, sem Pyricularia oryzae, com deficiência hídrica 5 dias após pleno florescimento).

Já para a variável NPAN (número de panículas), a maior média observada foi a do $\mathrm{T}_{2}$ (sementes não tratadas, com Pyricularia oryzae, com deficiência hídrica 10 dias antes pleno florescimento), que diferiu significativamente de $T_{5}, T_{8}$ (sementes não tratadas, sem Pyricularia oryzae), $\mathrm{T}_{9}, \mathrm{~T}_{11}$ e $\mathrm{T}_{12}$ (sementes tratadas, com Pyricularia oryzae), $\mathrm{T}_{13}, \mathrm{~T}_{15}$ e $\mathrm{T}_{16}$ (sementes tratadas, sem Pyricularia oryzae). A menor média foi a do $\mathrm{T}_{13}$ (sementes tratadas sem Pyricularia oryzae, sem deficiência hídrica). 


\subsubsection{Massa de raízes secas, massa de parte aérea seca, e massa de panículas secas}

Observa-se pela Tabela 26, que houve efeito significativo para tratamentos para as três variáveis, ao nível de $1 \%$ de probabilidade.

Tabela 26. Análise da variância (Quadrados médios) e teste $\mathrm{F}$ para as variáveis Massa de raízes secas (MRS), Massa de parte aérea seca (MPAS) e Massa de panículas secas (MPS), (segunda fase).

\begin{tabular}{lcccc}
\hline Causa da Variação & $\begin{array}{c}\text { Graus de } \\
\text { Liberdade }\end{array}$ & MRS & MPAS & MPS \\
\hline Tratamentos & 15 & $212,98855^{\prime \prime}$ & $389,81655^{*}$ & $429,217488^{* \prime}$ \\
Resíduo & 48 & 24,01004 & 68,67113 & 14,24338 \\
\hline Total & 65 & & \\
\hline \multicolumn{5}{l}{ "Significativo pelo teste F, ao nível de 1\% de probabilidade. }
\end{tabular}

O detalhamento da análise da variância, através do desdobramento dos graus de liberdade em contrastes ortogonais, pelo teste $\mathrm{F}$, apresentou o seguinte resultado, descrito na Tabela 27. 
Tabela 27. Desdobramento dos graus de liberdade de tratamentos (quadrados médios) em contrastes ortogonais, e teste $\mathrm{F}$, para as variáveis MRS (massa de raizes secas), MPAS (massa de parte aérea seca) e MPS (massa de panículas secas), (segunda fase).

\begin{tabular}{|c|c|c|c|c|}
\hline Causa da Variação & Graus de Liberdade & MRS & MPAS & MPS \\
\hline$\overline{Y_{1}}$ & 1 & $32,20561^{\mathrm{ns}}$ & $22,68134^{\mathrm{ns}}$ & $197,22699^{\prime \prime}$ \\
\hline $\mathrm{Y}_{2}$ & 1 & $106,94528^{*}$ & $237,07551^{\text {ns }}$ & $32,10008^{\text {ns }}$ \\
\hline $\mathrm{Y}_{3}$ & 1 & $622,80027^{* *}$ & $1123,26762^{* *}$ & $1568,65309^{* *}$ \\
\hline$Y_{4}$ & 1 & $40,04167^{\text {ns }}$ & $321,93371^{*}$ & $590,04182^{* *}$ \\
\hline $\mathrm{Y}_{5}$ & 1 & $6,48002^{\text {ns }}$ & $105,85129^{\text {ns }}$ & $26,64497^{\mathrm{ns}}$ \\
\hline$Y_{6}$ & 1 & $365,20326^{* *}$ & $247,97510^{\text {ns }}$ & $1297,39993^{* *}$ \\
\hline$Y_{7}$ & 1 & $3,01042^{\mathrm{ns}}$ & $243,20663^{\text {ns }}$ & $642,21738^{* *}$ \\
\hline$Y_{8}$ & 1 & $179,55119^{* *}$ & $62,71997^{\text {ns }}$ & $6,21282^{\text {ns }}$ \\
\hline$Y_{9}$ & 1 & $130,00781^{*}$ & $378,12521^{*}$ & $47,53132^{\mathrm{ns}}$ \\
\hline$Y_{10}$ & 1 & $779,24078^{* *}$ & $1446,50554^{* *}$ & $558,28508^{* *}$ \\
\hline$Y_{11}$ & 1 & $44,28160^{\text {ns }}$ & $678,40641^{* *}$ & $427,57057^{* *}$ \\
\hline $\mathrm{Y}_{12}$ & 1 & $27,37995^{\text {ns }}$ & $109,51982^{\text {ns }}$ & $47,53125^{\mathrm{ns}}$ \\
\hline $\mathrm{Y}_{13}$ & 1 & $807,70016^{* *}$ & $719,97540^{* *}$ & $493,4403^{* *}$ \\
\hline$Y_{14}$ & 1 & $20,72042^{\text {ns }}$ & $8,88167^{\text {ns }}$ & $42084388^{* *}$ \\
\hline$Y_{15}$ & 1 & $29,26126^{\text {ns }}$ & $141,12005^{\mathrm{ns}}$ & $82,56123^{*}$ \\
\hline Resíduo & 48 & 24,010004 & 68,67113 & 14,24338 \\
\hline Total & 63 & & & \\
\hline
\end{tabular}

* Significativo pelo teste $\mathrm{F}$, ao nível de $5 \%$.

** Significativo pelo teste $\mathrm{F}$, ao nível de $1 \%$.

ns Não significativo pelo teste F, considerando-se um nível mínimo de Significância (n.m.s) de 5\%.

Observa-se na Tabela 27 que, para a variável MRS (massa de raízes secas) foram significativos, os contrastes $\mathrm{Y}_{2}$ (sementes não tratadas versus tratadas, com Pyricularia oryzae), $\mathrm{Y}_{3}$ (sementes não tratadas, com Pyricularia oryzae, sem deficiência hídrica versus com deficiência hídrica), Y6 (sementes tratadas, com Pyricularia oryzae, sem deficiência hídrica versus com deficiência hídrica), $Y_{8}$ (sementes tratadas com Pyricularia oryzae, com deficiência hídrica 5 dias antes versus deficiência hídrica 10 dias antes pleno florescimento), Y9 (sementes não tratadas versus tratadas, sem Pyricularia oryzae), $\mathrm{Y}_{10}$ (sementes não tratadas, sem Pyricularia oryzae, sem deficiência hídrica versus com deficiência hídrica) e $\mathrm{Y}_{13}$ (sementes tratadas, sem Pyricularia oryzae, sem deficiência hídrica versus com deficiência hídrica).

As estimativas desses contrastes e seus indicativos estão descritas na Tabela 28. 
Tabela 28. Descrição das estimativas dos contrastes relativos à massa de raízes secas (MRS, $\mathrm{g} /$ vaso).

\begin{tabular}{|c|c|c|}
\hline Contrastes & Valor Estimado & Descrição \\
\hline$\overline{Y_{2}}$ & $+14,63$ & $\begin{array}{l}\text { As médias das sementes com Pyricularia oryzae, não tratadas } \\
\text { superaram as sementes tratadas com Pyricularia oryzae } \\
\text { (equação 13) }\end{array}$ \\
\hline $\mathrm{Y}_{3}$ & $-43,23$ & $\begin{array}{l}\text { As médias das sementes com Pyricularia oryzae, não tratadas e } \\
\text { com deficiência hídrica superaram as com Pyricularia oryzae, } \\
\text { não tratadas e sem deficiência hídrica (equação 14) }\end{array}$ \\
\hline Y6 & $-33,10$ & $\begin{array}{l}\text { As médias das sementes com Pyricularia oryzae, tratadas e com } \\
\text { deficiência hídrica superaram as sementes com Pyricularia } \\
\text { oryzae, tratadas e sem deficiência hídrica (equação 15) }\end{array}$ \\
\hline$Y_{8}$ & $+9,48$ & $\begin{array}{l}\text { A média das sementes com Pyricularia oryzae, tratadas e com } \\
\text { deficiência hídrica } 5 \text { dias antes do pleno florescimento } \\
\text { superaram as sementes com Pyricularia oryzae, tratadas e com } \\
\text { deficiência hídrica } 10 \text { dias antes do pleno florescimento } \\
\text { (equação 19) }\end{array}$ \\
\hline$Y_{9}$ & $+16,13$ & $\begin{array}{l}\text { As médias das sementes sem Pyricularia oryzae, não tratadas } \\
\text { superaram as sementes tratadas sem Pyricularia oryzae } \\
\text { (equação 20) }\end{array}$ \\
\hline $\mathrm{Y}_{10}$ & $-48,35$ & $\begin{array}{l}\text { As médias das sementes sem Pyricularia oryzae, não tratadas e } \\
\text { com deficiência hídrica superaram as sementes não tratadas sem } \\
\text { Pyricularia oryzae e sem deficiência hídrica (equação } 21 \text { ) }\end{array}$ \\
\hline$Y_{13}$ & $-49,23$ & $\begin{array}{l}\text { As médias das sementes sem Pyricularia oryzae, tratadas e com } \\
\text { deficiência hídrica superaram as sementes tratadas sem } \\
\text { Pyricularia oryzae e sem deficiência hídrica (equação 24) }\end{array}$ \\
\hline
\end{tabular}

Nota-se que o fungicida Pyroquilon não influenciou esta variável, a deficiência hídrica foi o fator que provocou diferenças entres os tratamentos. Stone et al. (1984) comentou que plantas de arroz submetidas a deficiência hídrica apresentaram um aumento na relação raiz/colmo, ou seja, houve uma maior produção de raizes quando comparado à plantas de arroz que não foram submetidas à deficiência hídrica. Não podemos discutir qual o comportamento da relação raiz/colmo nos tratamentos, mas fica evidente que os tratamentos com deficiência hídrica tiveram um aumento significativo na massa de raízes secas quando comparados aos tratamentos sem deficiência hídrica. Os dados obtidos, no entanto, são contrários aos resultados dos estudos de Pereira et al. (1994), que verificou uma redução na massa de raízes secas em plantas de arroz submetidas à deficiência hídrica. Essa discrepância pode ser explicada pelo reinício da irrigação nos tratamentos com 
deficiência hídrica, as plantas apresentaram um novo período de desenvolvimento produzindo uma maior massa de raízes.

Para a variável MPAS (massa de parte aérea seca) foram significativos, os contrastes $\mathrm{Y}_{3}$ (sementes não tratadas, com Pyricularia oryzae, sem deficiência hídrica versus com deficiência hídrica), $\mathrm{Y}_{4}$ (sementes não tratadas, com Pyricularia oryzae, com deficiência hídrica antes do pleno florescimento versus deficiência hídrica após pleno florescimento), Y9 ( sementes não tratadas versus sementes tratadas, sem Pyricularia oryzae), Y10 (sementes não tratadas, sem Pyricularia oryzae, sem deficiência hídrica versus com deficiência hídrica), $\mathrm{Y}_{11}$ (sementes não tratadas, sem Pyricularia oryzae, com deficiência hídrica antes do pleno florescimento versus deficiência hídrica após pleno florescimento) e $\mathrm{Y}_{13}$ (sementes tratadas, sem Pyricularia oryzae, sem deficiência hídrica versus com deficiência hídrica).

As estimativas dos contrastes e seus indicativos estão descrita na Tabela 29.

Tabela 29. Descrição das estimativas dos contrastes relativos à massa de parte aérea seca (MPAS, $\mathrm{g} /$ vaso).

\begin{tabular}{|c|c|c|}
\hline Contrastes & Valor Estimado & Descrição \\
\hline$\overline{Y_{3}}$ & $-58,05$ & $\begin{array}{l}\text { As médias das sementes com Pyricularia oryzae, não tratadas e com } \\
\text { deficiência hídrica superaram as sementes não tratadas com Pyricularia } \\
\text { oryzae e sem deficiência hídrica (equação 14) }\end{array}$ \\
\hline$Y_{4}$ & $+21,98$ & $\begin{array}{l}\text { As médias das sementes com Pyricularia oryzae, não tratadas e com } \\
\text { deficiência hídrica antes do pleno florescimento superaram as sementes } \\
\text { não tratadas com Pyricularia oryzae e com deficiência hídrica após o } \\
\text { pleno florescimento (equação 15) }\end{array}$ \\
\hline Y9 & $+27,50$ & $\begin{array}{l}\text { As médias das sementes sem Pyricularia oryzae, não tratadas } \\
\text { superaram as sementes tratadas, sem Pyricularia oryzae (equação 20) }\end{array}$ \\
\hline$Y_{10}$ & $-65,88$ & $\begin{array}{l}\text { As médias das sementes sem Pyricularia oryzae, não tratadas e com } \\
\text { deficiência hídrica superaram as sementes não tratadas sem Pyricularia } \\
\text { oryzae e sem deficiência hídrica (equação } 21 \text { ) }\end{array}$ \\
\hline $\mathrm{Y}_{11}$ & $+31,90$ & $\begin{array}{l}\text { As médias das sementes sem Pyricularia oryzae, não tratadas e com } \\
\text { deficiência hídrica antes do pleno florescimento superaram as sementes } \\
\text { não tratadas sem Pyricularia oryzae e com deficiência hídrica após o } \\
\text { pleno florescimento (equação 22) }\end{array}$ \\
\hline$Y_{13}$ & $-46,48$ & $\begin{array}{l}\text { As médias das sementes sem Pyricularia oryzae, tratadas e com } \\
\text { deficiência hídrica superaram as sementes tratadas sem Pyricularia } \\
\text { oryzae e sem deficiência hídrica (equação } 24 \text { ) }\end{array}$ \\
\hline
\end{tabular}


Novamente os tratamentos com deficiência hídrica foram significativamente diferentes dos tratamentos sem deficiência hídrica, e dentro dọ tratamentos com deficiência hídrica aqueles que sofreram a deficiência antes do florescimento diferiram daqueles que sofreram a deficiência após o florescimento, no entanto os efeitos causados pela deficiência hídrica foram mais uma vez antagônicos aos descritos em literatura, que reportam a diminuição da massa da parte aérea seca. Pode-se explicar essa discrepância de resultados pela retomada da irrigação após o período de deficiência hídrica nos tratamentos, o que provocou novo período de desenvolvimento vegetativo para as plantas, aumentando a massa de parte aérea seca quando comparados aos tratamentos sem deficiência. A escolha do florescimento como o período mais propício para se estudar os efeitos da deficiência hídrica em plantas de arroz foi também provado pelos resultados da variável massa da parte aérea seca. Esse resultado concorda com Fageria (1984) que comentou que os efeitos mais danosos da deficiência hídrica são observados quando esta acontece no período compreendido entre os estádios de divisão/redução até o florescimento, também concorda com Rodrigues (1985) que verificou que períodos de deficiência hídrica antes da floração do arroz são os mais adequados para a observação dos efeitos da deficiência nas plantas.

Para a variável MPS (massa de panículas secas) foram significativos, ao nível de $1 \%$ de probabilidade, os contrastes $\mathrm{Y}_{1}$ (sementes com Pyricularia oryzae versus sem Pyricularia oryzae), $\mathrm{Y}_{3}$ (sementes não tratadas, com Pyricularia oryzae, sem deficiência hídrica versus com deficiência hídrica), $\mathrm{Y}_{4}$ (sementes não tratadas, com Pyricularia oryzae com deficiência hídrica antes do pleno florescimento versus deficiência hídrica após pleno florescimento), $\mathrm{Y}_{6}$ (sementes tratadas, com Pyricularia oryzae, sem deficiência hídrica versus com deficiência hídrica), Y7 (sementes tratadas, com Pyricularia oryzae, com deficiência hídrica antes pleno florescimento versus deficiência hídrica após pleno florescimento), $\mathrm{Y}_{10}$ (sementes não tratadas, sem Pyricularia oryzae sem deficiência hídrica versus com deficiência hídrica), $\mathrm{Y}_{11}$ (sementes não tratadas, sem Pyricularia oryzae, com deficiência hídrica antes do pleno florescimento versus deficiência hídrica após pleno florescimento), $\mathrm{Y}_{13}$ (sementes tratadas, sem Pyricularia oryzae, sem deficiência hídrica versus com deficiência hídrica) e $\mathrm{Y}_{14}$ (sementes tratadas, sem Pyricularia oryzae, com 
deficiência hídrica antes do pleno florescimento versus com deficiência hídrica após pleno florescimento).

As estimativas dos contrastes e seus indicativos estão descritas na Tabela 30.

Tabela 30. Descrição das estimativas dos contrastes relativos à massa de panículas secas (MPS, g/vaso).

\begin{tabular}{|c|c|c|}
\hline Contrastes & Valor Estimado & Descrição \\
\hline$Y_{1}$ & $-28,09$ & $\begin{array}{l}\text { As médias das sementes sem Pyricularia oryzae superaram as com } \\
\text { Pyricularia oryzae (equação 12) }\end{array}$ \\
\hline $\mathrm{Y}_{3}$ & $+68,60$ & $\begin{array}{l}\text { As médias das sementes com Pyricularia oryzae, não tratadas e sem } \\
\text { deficiência hídrica superaram as sementes não tratadas com Pyricularia } \\
\text { oryzae e com deficiência hídrica (equação 14) }\end{array}$ \\
\hline$Y_{4}$ & $-29,75$ & $\begin{array}{l}\text { As médias da sementes com Pyricularia oryzae, não tratadas e com } \\
\text { deficiência hídrica após pleno florescimento superaram as sementes não } \\
\text { tratadas com Pyricularia oryzae e com deficiência hídrica antes do } \\
\text { pleno florescimento (equação 15) }\end{array}$ \\
\hline $\mathrm{Y}_{6}$ & $+62,39$ & $\begin{array}{l}\text { As médias das sementes com Pyricularia oryzae, tratadas e sem } \\
\text { deficiência hídrica superaram as sementes tratadas com Pyricularia } \\
\text { oryzae e com deficiência hídrica (equação 17) }\end{array}$ \\
\hline $\mathrm{Y}_{7}$ & $-31,04$ & $\begin{array}{l}\text { As médias das sementes com Pyricularia oryzae, tratadas e com } \\
\text { deficiência hídrica após pleno florescimento superaram as sementes } \\
\text { tratadas, com Pyricularia oryzae e com deficiência hídrica antes do } \\
\text { pleno florescimento (equação 18) }\end{array}$ \\
\hline$Y_{10}$ & $+40,93$ & $\begin{array}{l}\text { As médias das sementes sem Pyricularia oryzae, não tratadas e com } \\
\text { deficiência hídrica após pleno florescimento superaram as sementes não } \\
\text { tratadas, sem Pyricularia oryzae e com deficiência hídrica antes do } \\
\text { pleno florescimento (equação } 21 \text { ) }\end{array}$ \\
\hline $\mathrm{Y}_{13}$ & $+38,48$ & $\begin{array}{l}\text { As médias das sementes sem Pyricularia oryzae, tratadas e sem } \\
\text { deficiência hídrica superaram as sementes tratadas, sem Pyricularia } \\
\text { oryzae e com deficiência hídrica (equação } 24 \text { ) }\end{array}$ \\
\hline $\mathrm{Y}_{14}$ & $-25,23$ & $\begin{array}{l}\text { A média das sementes sem Pyricularia oryzae, tratadas e com } \\
\text { deficiência hídrica após pleno florescimento superaram as sementes } \\
\text { tratadas, sem Pyricularia oryzae e com deficiência hídrica antes do } \\
\text { pleno florescimento (equação } 25 \text { ) }\end{array}$ \\
\hline
\end{tabular}

A massa de panículas secas é a primeira variável até agora discutida que diretamente relacionada-se com a produção das plantas de arroz.

Os tratamentos sem Pyricularia oryzae apresentaram superioridade em relação aos tratamentos com Pyricularia oryzae, o que pode indicar que os patógenos presentes nas sementes podem estar interferindo na variável massa de panículas secas (MPS), no entanto é mais provável que em vez dos patógenos a qualidade das sementes seja o fator que 
influenciou as diferenças obtidas, pois as sementes com Pyricularia oryzae apresentavam menor vigor do que as sementes sem Pyricularia oryzae, estas últimas evidentemente com maior potencial produtivo.

A deficiência hídrica apresentou uma grande influência no desempenho dos tratamentos, aqueles com deficiência foram inferiores à aqueles sem deficiência, os resultados concordam com Fageria (1984) e Fornasieri Filho \& Fornasieri (1993), esses autores observaram uma redução na massa dos grãos com a ocorrência da deficiência hídrica, consequentemente uma redução na massa seca das panículas.

O período de ocorrência da deficiência hídrica no pré-florescimento resultou em menores massas de panículas secas, do que no pós-florescimento, todos os tratamentos onde a deficiência hídrica ocorreu no pré-florescimento foram inferiores aos tratamentos com deficiência no pós-florescimento, esses resultados concordam com os comentários de Vieira et al. (1991). 
Tabela 31. Resumo das estimativas dos contrastes para o grupo de variáveis massa de raízes secas (MRS), massa de parte aérea seca (MPAS) e massa de panículas secas (MPS), (segunda fase).

\begin{tabular}{cccc}
\hline Contrastes & MRS & MPAS & MPS \\
\hline$Y_{1}$ & $-11,35^{\text {ns }}$ & $-9,52^{\text {ns }}$ & $-28,09^{\text {ग* }}$ \\
$Y_{2}$ & $+14,63^{*}$ & $+21,78^{\text {ns }}$ & $-8,01^{\text {ns }}$ \\
$Y_{3}$ & $-43,23^{* *}$ & $-58,05^{* *}$ & $+68,60^{* *}$ \\
$Y_{4}$ & $+7,75^{\text {ns }}$ & $+21,98^{*}$ & $-29,75^{* *}$ \\
$Y_{5}$ & $+1,80^{\text {ns }}$ & $+7,27^{\text {ns }}$ & $-3,65^{\text {ns }}$ \\
$Y_{6}$ & $-33,10^{* *}$ & $-27,28^{\text {ns }}$ & $+62,39^{* *}$ \\
$Y_{7}$ & $+2,13^{\text {ns }}$ & $+19,10^{\text {ns }}$ & $-31,04^{* *}$ \\
$Y_{8}$ & $+9,48^{* *}$ & $+5,60^{\text {ns }}$ & $-1,76^{\text {ns }}$ \\
$Y_{9}$ & $+16,13^{*}$ & $+27,50^{*}$ & $-9,75^{\text {ns }}$ \\
$Y_{10}$ & $-48,35^{* *}$ & $-65,88^{* *}$ & $+40,93^{* *}$ \\
$Y_{11}$ & $+8,15^{\text {ns }}$ & $+31,90^{* *}$ & $-25,33^{* *}$ \\
$Y_{12}$ & $-3,70^{\text {ns }}$ & $-7,40^{\text {ns }}$ & $-4,88^{\text {ns }}$ \\
$Y_{13}$ & $-49,23^{* *}$ & $-46,48^{* *}$ & $+38,48^{* *}$ \\
$Y_{14}$ & $+5,58^{\text {ns }}$ & $+3,65^{\text {ns }}$ & $-25,13^{* *}$ \\
$Y_{15}$ & $+3,83^{\text {ns }}$ & $+8,40^{\text {ns }}$ & $-6,43^{*}$ \\
\hline
\end{tabular}

* Significativo pelo teste $\mathrm{F}$, ao nível de $5 \%$ de probabilidade.

** Significativo pelo teste $\mathrm{F}$, ao nível de $1 \%$ de probabilidade.

ns Não significativo pelo teste $\mathrm{F}$, considerando-se um nível mínimo de significância (n.m.s) de $5 \%$.

Para este grupo de variáveis também observa-se na Tabela 31, com certa sistematização, que os sinais dos contrastes para a variável MPS (massa de panículas secas) foram opostos aos sinais dos mesmos contrastes para as variáveis MRS (massa de raízes secas) e MPAS (massa de parte aérea seca), indicando, quando houve evidência de significância, que o melhor tratamento (ou grupo) para MRS (massa de raízes secas) e MPAS (massa de parte aérea seca) seria o pior para MPS (massa de panículas secas), e vice-versa. Os resultados obtidos são coerentes, pois a superioridade dos tratamentos com deficiência hídrica para as variáveis MPAS (massa de parte aérea seca) e MRS (massa de raízes secas) em relação os tratamentos sem deficiência hídrica é devida ao reinício da irrigação após os períodos de deficiência, e a retomada do desenvolvimento da plantas, as 
quais produziram mais massa foliar e radicular compensando a paralisação provocada pela deficiência, no entanto essa retomada de desenvolvimento não influenciou a variável MPS (massa de panículas secas), os tratamentos sem deficiência hídrica foram superiores aos tratamentos com deficiência hídrica.

O detalhamento da análise, através de contrastes das médias duas a duas, pelo teste de Duncan, apresentou o seguinte resultado está descrito na Tabela 32.

Tabela 32. Médias sem transformação e teste de Duncan para tratamentos, para as variáveis MRS (massa de raízes secas, g/vaso), MPAS (massa de parte aérea seca, g/vaso) e MPS (massa de panículas secas, $\mathrm{g} / \mathrm{vaso}$ ), (segunda fase).

\begin{tabular}{|c|c|c|c|}
\hline Tratamento & MRS & MPAS & MPS \\
\hline$T_{1}$ & $26,05 \mathrm{de}$ & 64,03 ef & $60,35 \quad a$ \\
\hline $\mathrm{T}_{2}$ & $42,65 \mathrm{ab}$ & $90,68 \mathrm{ab}$ & $30,70 \mathrm{j}$ \\
\hline$T_{3}$ & $40,85 \mathrm{ab}$ & $83,40 a b c$ & $34,35 \mathrm{ij}$ \\
\hline $\mathrm{T}_{4}$ & 37,88 abc & 76,05 cde & 47,40 ef \\
\hline $\mathrm{T}_{5}$ & $26,38 \mathrm{de}$ & 63,98 ef & $56,73 \mathrm{abc}$ \\
\hline $\mathrm{T}_{6}$ & $42,00 \mathrm{ab}$ & 87,55 abc & 36,43 hij \\
\hline $\mathrm{T}_{7}$ & 45,70 a & 94,95 a & $41,30 \mathrm{gh}$ \\
\hline $\mathrm{T}_{8}$ & 39,78 ab & 75,30 cdef & 51,53 cde \\
\hline $\mathrm{T}_{9}$ & $24,93 \mathrm{de}$ & 66,28 ef & 60,80 a \\
\hline $\mathrm{T}_{10}$ & $41,05 a b$ & 81,35 bcd & $33,95 \mathrm{ij}$ \\
\hline $\mathrm{T}_{11}$ & $31,58 \mathrm{~cd}$ & 75,75 cde & $35,71 \mathrm{hij}$ \\
\hline $\mathrm{T}_{12}$ & $35,25 \mathrm{bc}$ & $69,00 \mathrm{def}$ & 50,35 def \\
\hline $\mathrm{T}_{13}$ & 22,13 e & $61,95 \mathrm{f}$ & $58,55 \mathrm{ab}$ \\
\hline $\mathrm{T}_{14}$ & $41,38 \mathrm{ab}$ & 82,25 abcd & $38,33 \mathrm{hi}$ \\
\hline $\mathrm{T}_{15}$ & 37,55 bc & 73,85 cdef & $44,75 \mathrm{fg}$ \\
\hline $\mathrm{T}_{16}$ & $36,68 \mathrm{bc}$ & 76,23 cde & $54,10 \mathrm{bcd}$ \\
\hline
\end{tabular}

Médias seguidas de letras iguais, nas colunas, não diferem entre si ao nível de $5 \%$ de probabilidade.

Observa-se pela Tabela 32, que para as variáveis MRS (massa de raízes secas) e MPAS (massa de parte aérea seca), as maiores médias foram obtidas pelos tratamentos $\mathrm{T}_{7}$, $\mathrm{T}_{2}$ e $\mathrm{T}_{6}$ (nesta ordem), enquanto a menor média foi a do tratamento $\mathrm{T}_{13}$. Para essas duas 
variáveis observa-se claramente a formação de 3 grupos: $T 7, T_{2}, T_{6}, T_{14}, T_{3}, T_{10}$, maiores e iguais, $\mathrm{T}_{16}, \mathrm{~T}_{4}, \mathrm{~T}_{11}, \mathrm{~T}_{15}, \mathrm{~T}_{8}, \mathrm{~T}_{12}$, intermediários e $\mathrm{T}_{5}, \mathrm{~T}_{1}, \mathrm{~T}_{9}, \mathrm{~T}_{13}$, menores.

Já para a variável MPS (massa de panículas secas) as maiores médias ficaram com os tratamentos $T_{9}, T_{1}, T_{13}, T_{5}$ (nesta ordem) e a menor média com o $T_{2}$, seguido do $T_{10} e$ $\mathrm{T}_{3}$.

4.2.5 Massa de grãos cheios secos, massa de grãos chochos secos, número de grãos cheios, número de grãos chochos, e porcentagem de grãos cheios

Observa-se pela Tabela 33 que houve efeito significativo para tratamentos para todas as variáveis deste grupo.

Tabela 33. Análise da variância (quadrados médios) e teste $\mathrm{F}$ para as variáveis Massa de grãos cheios secos (MGCS, g/vaso), Massa de grãos chochos secos (MGCOS, g/vaso), Número de grãos cheios (NGC), Número de grãos chochos (NGCO), e Porcentagem de grãos cheios (\% GC), (segunda fase).

\begin{tabular}{lcccccl}
\hline C. Variação & G.L. & \multicolumn{1}{c}{ MGCS } & MGCOS $^{(\text {t) }}$ & \multicolumn{1}{c}{ NGC } & \multicolumn{1}{c}{ NGCO $^{(\text {t) }}$} & \multicolumn{1}{c}{$\%$ GC } \\
\hline Tratamentos & 15 & $636,53985^{* *}$ & $1,40082^{* *}$ & $437431,42917^{* *}$ & $228,13520^{* *}$ & $1222,81699^{* *}$ \\
Resíduo & 48 & 5,37967 & 0,10663 & 31632,04167 & 12,98560 & 49,92013 \\
\hline Total & 65 & & & & &
\end{tabular}

(t) Análise realizada com os dados transformados através de raiz quadrada.

** Significativo pelo teste $\mathrm{F}$, ao nível de $1 \%$ de probabilidade.

O detalhamento da análise da variância, através do desdobramento dos graus de liberdade em contrastes ortogonais, pelo teste $\mathrm{F}$, apresentou o seguinte resultado descritos na Tabela 34. 
Tabela 34. Desdobramento dos graus de liberdade de tratamentos em contrastes ortogonais (quadrados médios), e teste $\mathrm{F}$, para as variáveis MGCS (massa de grãos cheios secos), MGCOS (massa de grãos chochos secos), NGC (número de grãos cheios), NGCO (número de grãos chochos) e \% GC (porcentagem de grãos cheios), (segunda fase).

\begin{tabular}{|c|c|c|c|c|c|c|}
\hline C. Variação & G.L. & MGCS & $\underset{(t)}{\operatorname{MGCOS}}$ & $\overline{\text { NGC }}$ & $\underset{(t)}{\mathrm{NGCO}}$ & $\% \mathrm{GC}$ \\
\hline$\overline{Y_{1}}$ & 1 & $176,09299^{27}$ & $0,19066^{\mathrm{ns}}$ & $3306,25000^{\mathrm{ns}}$ & $45,41105^{\text {ns }}$ & $77,74822^{\text {ns }}$ \\
\hline $\mathrm{Y}_{2}$ & 1 & $29,24214^{*}$ & $0,16053^{\text {ns }}$ & $77322,78125^{\mathrm{ns}}$ & $69,06451^{*}$ & $328,44848^{*}$ \\
\hline$Y_{3}$ & 1 & $2054,99907^{* *}$ & $2,61268^{* *}$ & $603456,75000^{* *}$ & $479,50020^{\prime *}$ & $2275,35495^{* *}$ \\
\hline $\mathrm{Y}_{4}$ & 1 & $920,32938^{* *}$ & $2,96350^{* *}$ & $1088856,00000^{* \prime}$ & $362,47176^{* *}$ & $2301,43313^{* *}$ \\
\hline Y5 & 1 & $134,15222^{* *}$ & $0,49173^{*}$ & $441800,00000^{* *}$ & $103,20004^{*}$ & $898,45602^{* *}$ \\
\hline $\mathrm{y}_{6}$ & 1 & $1716,49894^{* *}$ & $3,04691^{* *}$ & $474615,18750^{* *}$ & $181,78303^{* *}$ & $1038,25123^{* *}$ \\
\hline $\mathrm{Y}_{7}$ & 1 & $1021,81548^{* *}$ & $1,95065^{* *}$ & $452101,50000^{* *}$ & $299,08159^{* *}$ & $1570,43179^{* *}$ \\
\hline$Y_{8}$ & 1 & $58,86123^{* *}$ & $0,73147^{\circ}$ & $840,50000^{\text {ns }}$ & $89,95180^{*}$ & $198,40332^{\circ}$ \\
\hline$Y_{9}$ & 1 & $93,81078^{* *}$ & $0,10704^{\text {ns }}$ & $86216,28125^{\text {ns }}$ & $123,15995^{* *}$ & $533,99071^{* *}$ \\
\hline$Y_{10}$ & 1 & $798,78246^{* *}$ & $2,48590^{* *}$ & $451632,00000^{* *}$ & $671,79232^{* *}$ & $2937,66087^{* *}$ \\
\hline$Y_{11}$ & 1 & $796,60835^{* *}$ & $2,57411^{* *}$ & $1549908,37500^{* *}$ & $412,16003^{* *}$ & $2896,08572^{* *}$ \\
\hline$Y_{12}$ & 1 & $107,53107^{* *}$ & $0,00001^{\text {ns }}$ & $5671,12500^{\text {ns }}$ & $0,35233^{\text {ns }}$ & $1,53125^{\mathrm{ns}}$ \\
\hline $\mathrm{Y}_{13}$ & 1 & $769,12034^{* *}$ & $2,30648^{* *}$ & $441408,52083^{* *}$ & $341,40568^{* *}$ & $1558,95025^{* *}$ \\
\hline $\mathrm{Y}_{14}$ & 1 & $710,13755^{* *}$ & $0,56250^{*}$ & $731155,04167^{* *}$ & $142,71875^{* *}$ & $1119,29992^{* *}$ \\
\hline$Y_{15}$ & 1 & $160,11566^{* *}$ & $0,82811^{* *}$ & $153181,12500^{* *}$ & $99,97454^{* *}$ & $606,21646^{* *}$ \\
\hline Resíduo & 48 & 5,37967 & 0,10663 & 31632,04167 & 12,98560 & 49,92013 \\
\hline Total & 63 & & & & & \\
\hline
\end{tabular}

(t) Análise realizada com os dados transformados através de raiz quadrada.

* Significativo pelo teste $\mathrm{F}$, ao nivel de $5 \%$ de probabilidade.

** Significativo pelo teste $\mathrm{F}$, ao nível de $1 \%$ de probabilidade.

ns Não significativo pelo teste F, considerando-se um nível mínimo de signifícância (n.m.s) de 5\%.

Observa-se que, para este grupo de variáveis, poucos contrastes foram não significativos.

Para a variável MGCS (massa de grãos cheios secos), todos os contrastes estabelecidos foram significativos. As estimativas desses contrastes e seus indicativos estão descritos na Tabela 35 . 
Tabela 35. Descrição das estimativas dos contrastes relativos à massa de grãos cheios secos (MGCS, g/vaso).

\begin{tabular}{|c|c|c|}
\hline Contrastes & $\begin{array}{c}\text { Valor } \\
\text { Estimado } \\
\end{array}$ & Descrição \\
\hline$\overline{Y_{1}}$ & $-26,54$ & $\begin{array}{l}\text { As médias das sementes com Pyricularia oryzae superaram as sementes sem Pyricularia } \\
\text { oryzae (equação 12) }\end{array}$ \\
\hline $\mathrm{Y}_{2}$ & $-7,65$ & $\begin{array}{l}\text { As médias das sementes com Pyricularia oryzae, tratadas superaram as sementes não tratadas } \\
\text { com Pyricularia oryzae (equação 13) }\end{array}$ \\
\hline $\mathrm{Y}_{3}$ & $+78,52$ & $\begin{array}{l}\text { As médias das sementes com Pyricularia oryzae, não tratadas e sem deficiência hídrica } \\
\text { superaram as com deficiência hídrica (equação 14) }\end{array}$ \\
\hline$Y_{4}$ & $-37,16$ & $\begin{array}{l}\text { As médias das sementes com Pyricularia oryzae, não tratadas e com deficiência hídrica após } \\
\text { pleno florescimento superaram as com deficiência hídrica antes do pleno florescimento } \\
\text { (equação 15) }\end{array}$ \\
\hline $\mathrm{Y}_{5}$ & $-8,19$ & $\begin{array}{l}\text { As médias das sementes com Pyricularia oryzae, não tratadas e com deficiência hídrica } 5 \\
\text { dias antes do pleno florescimento, superaram as com deficiência hídrica } 10 \text { dias antes do } \\
\text { pleno florescimento (equação 16) }\end{array}$ \\
\hline Y6 & $+71,76$ & $\begin{array}{l}\text { As médias das sementes com Pyricularia oryzae, tratadas e sem deficiência hídrica } \\
\text { superaram as com deficiência hídrica (equação 17) }\end{array}$ \\
\hline $\mathrm{Y}_{7}$ & $-39,15$ & $\begin{array}{l}\text { As médias das sementes com Pyricularia oryzae, tratadas e com deficiência hídrica após o } \\
\text { pleno florescimento superaram as com deficiência hídrica antes do pleno florescimento } \\
\text { (equação 18) }\end{array}$ \\
\hline$Y_{8}$ & $-5,43$ & $\begin{array}{l}\text { As médias das sementes com Pyricularia oryzae, tratadas e com deficiência hídrica } 5 \text { dias } \\
\text { antes do pleno florescimento, superaram as de } 10 \text { dias antes do pleno florescimento (equação } \\
\text { 19) }\end{array}$ \\
\hline$Y_{9}$ & $-13,70$ & $\begin{array}{l}\text { As médias das sementes sem Pyricularia oryzae, tratadas, superaram, as sementes não } \\
\text { tratadas sem Pyricularia oryzae (equação 20) }\end{array}$ \\
\hline$Y_{10}$ & $+48,95$ & $\begin{array}{l}\text { As médias das sementes sem Pyricularia oryzae, não tratadas e sem deficiência hídrica } \\
\text { superaram as com deficiência hídrica (equação } 21 \text { ) }\end{array}$ \\
\hline$Y_{11}$ & $-34,57$ & $\begin{array}{l}\text { As médias das sementes sem Pyricularia oryzae, não tratadas e com deficiência hidrica após } \\
\text { pleno florescimento superaram as com deficiência hídrica antes do pleno florescimento } \\
\text { (equação 22) }\end{array}$ \\
\hline$Y_{12}$ & $-7,33$ & $\begin{array}{l}\text { As médias das sementes sem Pyricularia oryzae, não tratadas, e com deficiência hídrica } 5 \\
\text { dias antes, superaram as de } 10 \text { dias antes do pleno florescimento (equação } 23 \text { ) }\end{array}$ \\
\hline$Y_{13}$ & $+48,04$ & $\begin{array}{l}\text { As médias das sementes sem Pyricularia oryzae, tratadas e sem deficiência hídrica } \\
\text { superaram as com deficiência hídrica (equação 24) }\end{array}$ \\
\hline$Y_{14}$ & $-32,64$ & $\begin{array}{l}\text { As médias da sementes sem Pyricularia oryzae, tratadas e com deficiência hídrica após o } \\
\text { pleno florescimento superaram as com deficiência hídrica antes do pleno florescimento } \\
\text { (equação 25) }\end{array}$ \\
\hline $\mathrm{Y}_{15}$ & $-6,43$ & $\begin{array}{l}\text { As médias das sementes sem Pyricularia oryzae, tratadas e com deficiência hídrica } 5 \text { dias } \\
\text { antes do pleno florescimento, superaram as de } 10 \text { dias antes do pleno florescimento (equação } \\
\text { 26) }\end{array}$ \\
\hline
\end{tabular}

Nota-se que os patógenos presentes nas sementes não influenciaram essa variável, MGCS (massa de grãos cheios secos) que mede a produção das plantas, no entanto as sementes tratadas, com ou sem Pyricularia oryzae, apresentaram superioridade às sementes não tratada, com ou sem doença, demonstrando um efeito positivo do Pyroquilon sob essa variável. Todos os tratamentos sem deficiência hídrica foram superiores a todos os tratamentos com deficiência, os tratamentos com deficiência hídrica após o pleno florescimento foram superiores aos tratamentos com deficiência antes do pleno 
florescimento, ainda pode-se observar que os tratamentos com deficiência hídrica 5 dias antes do pleno florescimento foram superiores aos tratamentos com deficiência 10 dias antes, o que evidencia que quanto maior a duração da deficiência hídrica maiores foram os decréscimos na variável estudada, esses resultados estão de acordo com as observações de Fageria (1984), Fornasieri Filho \& Fornasieri (1993), Stone et al. (1984), e Pereira et al. (1994), que verificaram um decréscimo na massa de grãos em plantas de arroz submetidas à deficiência hídrica, bem como o período mais crítico para o ocorrência dessa deficiência situa-se no pré-florescimento das plantas

Para a variável MGCOS (massa de grãos chochos secos) apenas os contrastes $\mathrm{Y}_{1}$ (sementes com Pyricularia oryzae versus sem Pyricularia oryzae), Y2 (sementes não tratadas versus tratadas, com Pyricularia oryzae), Y9 (sementes não tratadas versus tratadas, sem Pyricularia oryzae) e $\mathrm{Y}_{12}$ (sementes não tratadas sem Pyricularia oryzae, com deficiência hídrica 5 dias antes versus 10 dias antes do pleno florescimento) não foram significativos.

As estimativas dos demais contrastes, significativos para esta variável, obtidas com as médias sem transformação, e seus indicativos estão descritos na Tabela 36. 
Tabela 36. Descrição das estimativas dos contrastes relativos à massa de grãos chochos secos (MGCOS, g/vaso).

\begin{tabular}{|c|c|c|}
\hline Contrastes & $\begin{array}{c}\text { Valor } \\
\text { Estimado }\end{array}$ & Descrição \\
\hline$\overline{Y_{3}}$ & $-11,29$ & $\begin{array}{l}\text { As médias das sementes com Pyricularia oryzae, não tratadas e com deficiência } \\
\text { hídrica superaram as sem deficiência hídrica (equação 14) }\end{array}$ \\
\hline $\mathrm{Y}_{4}$ & $+9,50$ & $\begin{array}{l}\text { As médias das sementes com Pyricularia oryzae, não tratadas e com deficiência } \\
\text { hídrica antes do pleno florescimento superaram as com deficiência hídrica após } \\
\text { pleno florescimento (equação 15) }\end{array}$ \\
\hline$Y_{5}$ & $+2,48$ & $\begin{array}{l}\text { As médias das sementes com Pyricularia oryzae, não tratadas e com deficiência } \\
\text { hídrica } 10 \text { dias antes do pleno florescimento superaram as com } 5 \text { dias antes do } \\
\text { pleno florescimento (equação 16) }\end{array}$ \\
\hline Y6 & $-11,22$ & $\begin{array}{l}\text { As médias das sementes com Pyricularia oryzae, tratadas e com deficiência } \\
\text { hídrica superaram as sem deficiência hídrica (equação 17) }\end{array}$ \\
\hline$Y_{7}$ & $+7,44$ & $\begin{array}{l}\text { As médias das sementes com Pyricularia oryzae, tratadas e com deficiência } \\
\text { hídrica antes do pleno florescimento superaram as com deficiência hídrica após } \\
\text { pleno florescimento (equação 18) }\end{array}$ \\
\hline$Y_{8}$ & $+3,05$ & $\begin{array}{l}\text { As médias das sementes com Pyricularia oryzae, tratadas e com deficiência } \\
\text { hídrica } 10 \text { dias antes do pleno florescimento superaram as de } 5 \text { dias antes do } \\
\text { pleno florescimento (equação 19) }\end{array}$ \\
\hline$Y_{10}$ & $-10,16$ & $\begin{array}{l}\text { As médias das sementes sem Pyricularia oryzae, não tratadas e com deficiência } \\
\text { hídrica superaram as sem deficiência hídrica (equacão 21) }\end{array}$ \\
\hline$Y_{11}$ & $+7,93$ & $\begin{array}{l}\text { As médias das sementes sem Pyricularia oryzae, não tratadas e com deficiência } \\
\text { hídrica antes do pleno florescimento superaram as com deficiência hídrica após } \\
\text { pleno florescimento (equação } 22 \text { ) }\end{array}$ \\
\hline $\mathrm{Y}_{13}$ & $-9,22$ & $\begin{array}{l}\text { As médias das sementes sem Pyricularia oryzae, tratadas e com deficiência } \\
\text { hidrica superaram as sem deficiência hídrica (equação 24) }\end{array}$ \\
\hline $\mathrm{Y}_{14}$ & $+4,04$ & $\begin{array}{l}\text { As médias das sementes sem Pyricularia oryzae, tratadas e com deficiência } \\
\text { hídrica antes do pleno florescimento superaram as com deficiência hídrica após } \\
\text { pleno florescimento (equação } 25 \text { ) }\end{array}$ \\
\hline$Y_{15}$ & $+2,85$ & $\begin{array}{l}\text { As médias das sementes tratadas, sem Pyricularia oryzae e com deficiência } \\
\text { hídrica } 10 \text { dias antes do pleno florescimento superaram as de } 5 \text { dias antes do } \\
\text { pleno florescimento (equação } 26 \text { ) }\end{array}$ \\
\hline
\end{tabular}

Os resultados obtidos para a variável MGCOS (massa de grãos chochos secos) foram totalmente contrários dos resultados obtidos para a variável MGCS (massa de grãos cheios secos). Todos os tratamentos com deficiência hídrica foram superiores aos tratamentos sem deficiência hídrica, todos os tratamentos com deficiência hídrica antes do pleno florescimento foram superiores aos tratamentos com deficiência após o pleno florescimento, todos os tratamentos com 10 dias de deficiência hídrica antes do pleno florescimento foram superiores aos tratamentos com 5 dias de deficiência antes do pleno florescimento, esses resultados concordam com Fageria (1984) e Fornasieri Filho \& 
Fornasieri (1993) que verificaram que a deficiência hídrica antes do pleno florescimento aumentava a massa de grãos chochos.

Para a variável NGC (número de grãos cheios) não foram significativos apenas os contrastes $\mathrm{Y}_{1}$ (sementes com Pyricularia oryzae versus sem Pyricularia oryzae), $\mathrm{Y}_{2}$ (sementes não tratadas versus tratada, com Pyricularia oryzae), $\mathrm{Y}_{8}$ (sementes com Pyricularia oryzae, tratadas, com deficiência hídrica 5 dias antes versus deficiência hídrica 10 dias antes pleno florescimento), Y9 (sementes não tratadas versus tratadas, sem Pyricularia oryzae) e $\mathrm{Y}_{12}$ (sementes sem Pyricularia oryzae, não tratadas, com deficiência hídrica 5 dias antes versus 10 dias antes pleno florescimento).

Os demais contrastes foram todos significativos. Suas estimativas e seus indicativos estão descritos na Tabela 37. 
Tabela 37. Descrição das estimativas dos contrastes relativos ao número de grãos cheios (NGC).

\begin{tabular}{|c|c|c|}
\hline Contrastes & Valor Estimado & Descrição \\
\hline$Y_{3}$ & $+1345,50$ & $\begin{array}{l}\text { As médias das sementes com Pyricularia oryzae, não tratadas, sem } \\
\text { deficiência hídrica superaram as com deficiência hídrica (equação 14) }\end{array}$ \\
\hline $\mathrm{Y}_{4}$ & $-1278,00$ & $\begin{array}{l}\text { As médias das sementes com Pyricularia oryzae, não tratadas e com } \\
\text { deficiência hídrica após o pleno florescimento superaram as com deficiência } \\
\text { hídrica antes do pleno florescimento (equação 15) }\end{array}$ \\
\hline $\mathrm{Y}_{5}$ & $-470,00$ & $\begin{array}{l}\text { As médias das sementes com Pyricularia oryzae, não tratadas e com } \\
\text { deficiência hídrica } 5 \text { dias antes do pleno florescimento superaram as de } 10 \\
\text { dias antes do pleno florescimento (equação } 16 \text { ) }\end{array}$ \\
\hline Y6 & $+1193,25$ & $\begin{array}{l}\text { As médias das sementes com Pyricularia oryzae, tratadas e sem deficiência } \\
\text { hídrica superaram as com deficiência hídrica (equação 16) }\end{array}$ \\
\hline$Y_{7}$ & $-823,50$ & $\begin{array}{l}\text { As médias das sementes com Pyricularia oryzae, tratadas e com deficiência } \\
\text { hídrica após o pleno florescimento superaram as com deficiência hídrica } \\
\text { antes do pleno florescimento (equação 18) }\end{array}$ \\
\hline $\mathrm{Y}_{10}$ & $+1164,00$ & $\begin{array}{l}\text { As médias das sementes sem Pyricularia oryzae, não tratadas e sem } \\
\text { deficiência hídrica superaram as com deficiência hídrica (equação } 21 \text { ) }\end{array}$ \\
\hline $\mathrm{Y}_{11}$ & $-1524,75$ & $\begin{array}{l}\text { As médias das sementes sem Pyricularia oryzae, não tratadas e com } \\
\text { deficiência hídrica após o pleno florescimento superaram as com deficiência } \\
\text { hídrica antes da pleno florescimento (equação 22) }\end{array}$ \\
\hline $\mathrm{Y}_{13}$ & $+1150,75$ & $\begin{array}{l}\text { As médias das sementes sem Pyricularia oryzae, tratadas e sem deficiência } \\
\text { hídrica superaram as com deficiência hídrica (equação } 24 \text { ) }\end{array}$ \\
\hline $\mathrm{Y}_{14}$ & $-1047,25$ & $\begin{array}{l}\text { As médias das sementes sem Pyricularia oryzae, tratadas e com deficiência } \\
\text { hídrica superaram as com deficiência hídrica (equação } 25 \text { ) }\end{array}$ \\
\hline$Y_{15}$ & $-276,75$ & $\begin{array}{l}\text { As médias das sementes sem Pyricularia oryzae, tratadas e com deficiência } \\
\text { hídrica } 5 \text { dias antes do pleno florescimento superaram as de } 10 \text { dias antes da } \\
\text { pleno florescimento (equação 26) }\end{array}$ \\
\hline
\end{tabular}

Os resultados relativos à variável número de grãos cheios (NGC) comportaram-se de maneira similar aos resultados relativos à variável MGCS (massa de grãos cheios secos). Quase todos os tratamentos sem deficiência hídrica foram superiores aos tratamentos com deficiência hídrica, os tratamentos com deficiência hídrica após o pleno florescimento foram superiores aos tratamentos com deficiência hídrica antes do pleno florescimento, também quase todos os tratamentos com deficiência hidrica 5 dias antes do pleno florescimento foram superiores aos tratamentos com deficiência hídrica 10 dias antes, resultados concordantes com Stone et al. (1984) e Pereira et al. (1994).

Para a variável NGCO (número de grãos chochos) apenas os contratantes $\mathrm{Y}_{1}$ (sementes com Pyricularia oryzae versus sem Pyricularia oryzae) e $\mathrm{Y}_{12}$ (sementes sem Pyricularia oryzae, não tratadas, com deficiência hídrica 5 dias antes versus 10 dias antes do pleno florescimento) não foram significativas. 
As estimativas das demais contrastes, todos significativos para essa variável, obtidas com as médias sem transformação, e seus indicativos estão descritas na Tabela 38.

Tabela 38. Descrição das estimativas dos contrastes relativos ao número de grãos chochos (NGCO).

\begin{tabular}{|c|c|c|}
\hline Contrastes & $\begin{array}{c}\text { Valor } \\
\text { Estimado } \\
\end{array}$ & Descrição \\
\hline$\overline{Y_{2}}$ & $+789,50$ & $\begin{array}{l}\text { As médias das sementes com Pyricularia oryzae superaram as sem Pyricularia } \\
\text { oryzae (equação 13) }\end{array}$ \\
\hline$Y_{3}$ & $-2180,25$ & $\begin{array}{l}\text { As médias das sementes com Pyricularia oryzae, não tratadas e com deficiência } \\
\text { hídrica superaram as sem deficiência hídrica (equação 14) }\end{array}$ \\
\hline$Y_{4}$ & $+1503,00$ & $\begin{array}{l}\text { As médias das sementes com Pyricularia oryzae, não tratadas e com deficiência } \\
\text { hídrica antes do pleno florescimento superaram as com deficiência hídrica após } \\
\text { o pleno florescimento (equação 15) }\end{array}$ \\
\hline$Y_{5}$ & $+497,50$ & $\begin{array}{l}\text { As médias das sementes com Pyricularia oryzae, não tratadas e com deficiência } \\
\text { hídrica } 10 \text { dias antes do pleno florescimento superaram as de } 5 \text { dias antes do } \\
\text { pleno florescimento (equação } 16 \text { ) }\end{array}$ \\
\hline Y6 & $-1281,75$ & $\begin{array}{l}\text { As médias das sementes com Pyricularia oryzae, tratadas e com deficiência } \\
\text { hídrica superaram as sem deficiência hídrica (equação 17) }\end{array}$ \\
\hline$Y_{7}$ & $+1160,25$ & $\begin{array}{l}\text { As médias das sementes com Pyricularia oryzae, tratadas e com deficiência } \\
\text { hídrica antes do pleno florescimento superaram as com deficiência hídrica após } \\
\text { o pleno florescimento (equação 18) }\end{array}$ \\
\hline$Y_{8}$ & $+443,75$ & $\begin{array}{l}\text { As médias das sementes com Pyricularia oryzae, tratadas e com deficiência } \\
\text { hídrica } 10 \text { dias antes do pleno florescimento superaram as de } 5 \text { dias antes do } \\
\text { pleno florescimento (equação 19) }\end{array}$ \\
\hline$Y_{9}$ & $+944,75$ & $\begin{array}{l}\text { As médias das sementes sem Pyricularia oryzae, não tratadas superaram as } \\
\text { tratadas (equação 20) }\end{array}$ \\
\hline$Y_{10}$ & $-2305,50$ & $\begin{array}{l}\text { As médias das sementes com Pyricularia oryzae, não tratadas e com deficiência } \\
\text { hídrica superaram as sem deficiência hídrica (equação 21) }\end{array}$ \\
\hline$Y_{11}$ & $+1494,00$ & $\begin{array}{l}\text { As médias das sementes sem Pyricularia oryzae, não tratadas e com deficiência } \\
\text { hídrica antes do pleno florescimento superaram as com deficiência hídrica após } \\
\text { o pleno florescimento (equação 22) }\end{array}$ \\
\hline$Y_{13}$ & $+1481,75$ & $\begin{array}{l}\text { As médias das sementes sem Pyricularia oryzae, tratadas e com deficiência } \\
\text { hídrica superaram as sem deficiência hídrica (equação 24) }\end{array}$ \\
\hline $\mathrm{Y}_{14}$ & $+809,00$ & $\begin{array}{l}\text { As médias das sementes sem Pyricularia oryzae, tratadas e com deficiência } \\
\text { hídrica antes do pleno florescimento superaram as com deficiência hídrica após } \\
\text { o pleno florescimento (equação } 25 \text { ) }\end{array}$ \\
\hline$Y_{15}$ & $+408,00$ & $\begin{array}{l}\text { As médias das sementes sem Pyricularia oryzae, tratadas e com deficiência } \\
\text { hídrica } 10 \text { dias antes do pleno florescimento superaram as de } 5 \text { dias antes do } \\
\text { pleno florescimento (equação } 26 \text { ) }\end{array}$ \\
\hline
\end{tabular}

Os resultados relativos à variável NGCO (número de grãos chochos) comportaram-se de maneira inversa aos resultados relativos à variável NGC (número de grãos cheios). Quase todos os tratamentos com deficiência hidrica foram superiores aos 
tratamentos sem deficiência hídrica, quase todos os tratamentos com deficiência hídrica antes do pleno florescimento foram superiores ao tratamentos com deficiência hídrica depois, também quase todos os tratamentos com deficiência hídrica durante o período de 10 dias antes do pleno florescimento foram superiores aos tratamentos com deficiência hídrica durante o período de 5 dias antes. Podemos notar também, que os patógenos presentes nas sementes não interferiram nesta variável, pois os tratamentos de sementes com Pyricularia oryzae foram superiores aos tratamentos de sementes sem Pyricularia oryzae. O Pyroquilon não influenciou os resultados obtidos para esta variável.

Para a variável \% GC (porcentagem de grãos cheios) também apenas os contrastes $\mathrm{Y}_{1}$ (sementes com Pyricularia oryzae versus sem Pyricularia oryzae) $\mathrm{Y}_{12}$ (sementes sem Pyricularia oryzae, não tratadas, com deficiência hídrica 5 dias antes versus 10 dias antes do pleno florescimento) não foram significativos.

As estimativas dos demais contrastes, todos significativos para essa variável, e seus indicativos estão descritas na Tabela 39 . 
Tabela 39. Descrição das estimativas dos contrastes relativos a porcentagem de grãos cheios (\% GC).

\begin{tabular}{|c|c|c|}
\hline Contrastes & $\begin{array}{c}\text { Valor } \\
\text { Estimado }\end{array}$ & Descrição \\
\hline$\overline{Y_{2}}$ & $-25,63$ & $\begin{array}{l}\text { As médias das sementes com Pyricularia oryzae, tratadas, superaram as } \\
\text { sementes não tratadas (equação } 13 \text { ) }\end{array}$ \\
\hline $\mathrm{Y}_{3}$ & $+82,62$ & $\begin{array}{l}\text { As médias das sementes com Pyricularia oryzae, não tratadas e sem deficiência } \\
\text { hídrica superaram as com deficiência hídrica (equação 14) }\end{array}$ \\
\hline$Y_{4}$ & $-58,76$ & $\begin{array}{l}\text { As médias das sementes com Pyricularia oryzae, não tratadas e com deficiência } \\
\text { hídrica após o pleno florescimento superaram as com deficiência hídrica antes } \\
\text { do pleno florescimento (equação 15) }\end{array}$ \\
\hline$Y_{5}$ & $-21,20$ & $\begin{array}{l}\text { As médias das sementes com Pyricularia oryzae, não tratadas e com deficiência } \\
\text { hídrica } 5 \text { dias antes do pleno florescimento superaram as de } 10 \text { dias antes do } \\
\text { pleno florescimento (equação } 16 \text { ) }\end{array}$ \\
\hline Y6 & $+55,81$ & $\begin{array}{l}\text { As médias das sementes com Pyricularia oryzae, tratadas e sem deficiência } \\
\text { hídrica superaram as com deficiência hídrica (equação } 17 \text { ) }\end{array}$ \\
\hline $\mathrm{Y}_{7}$ & $-48,54$ & $\begin{array}{l}\text { As médias das sementes com Pyricularia oryzae, tratadas e com deficiência } \\
\text { hídrica após o pleno florescimento superaram as com deficiência hídrica antes } \\
\text { do pleno florescimento (equação 18) }\end{array}$ \\
\hline $\mathrm{Y}_{8}$ & $-9,96$ & $\begin{array}{l}\text { As médias das sementes com Pyricularia oryzae, tratadas e com deficiência } \\
\text { hídrica } 5 \text { dias antes do pleno florescimento superaram as de } 10 \text { dias antes do } \\
\text { pleno florescimento (equação 19) }\end{array}$ \\
\hline$Y_{9}$ & $-32,68$ & $\begin{array}{l}\text { As médias das sementes sem Pyricularia oryzae, tratadas superaram as sementes } \\
\text { não tratadas (equação 20) }\end{array}$ \\
\hline$Y_{10}$ & $+93,88$ & $\begin{array}{l}\text { As médias das sementes sem Pyricularia oryzae, não tratadas e sem deficiência } \\
\text { hídrica superaram as com deficiência hídrica (equação } 21 \text { ) }\end{array}$ \\
\hline$Y_{11}$ & $-65,91$ & $\begin{array}{l}\text { As médias das sementes sem Pyricularia oryzae, não tratadas e com deficiência } \\
\text { hídrica após o pleno florescimento superaram as com deficiência hídrica antes } \\
\text { do pleno florescimento (equação 22) }\end{array}$ \\
\hline$Y_{13}$ & $+68,39$ & $\begin{array}{l}\text { As médias das sementes sem Pyricularia oryzae, tratadas e sem deficiência } \\
\text { hídrica superaram as com deficiência hídrica (equação 24) }\end{array}$ \\
\hline$Y_{14}$ & $-40,98$ & $\begin{array}{l}\text { As médias das sementes sem Pyricularia oryzae, tratadas e com deficiência } \\
\text { hídrica após o pleno florescimento superaram as com deficiência hídrica antes } \\
\text { do pleno florescimento (equação } 25 \text { ) }\end{array}$ \\
\hline$Y_{15}$ & $-17,41$ & $\begin{array}{l}\text { As médias das sementes sem Pyricularia oryzae, tratadas e com deficiência } \\
\text { hídrica } 5 \text { dias antes do pleno florescimento superaram as de } 10 \text { dias antes do } \\
\text { pleno florescimento (equação } 26 \text { ) }\end{array}$ \\
\hline
\end{tabular}

Os resultados obtidos para a variável porcentagem de grãos cheios (\% GC) são conseqüência do comportamento das variáveis número de grãos cheios (NGC) e número de grãos chochos). Quase todos os tratamentos sem deficiência hídrica superaram os tratamentos com deficiência hídrica, quase todos os tratamentos com deficiência hídrica antes do pleno florescimento superaram os tratamentos com deficiência hídrica após o pleno florescimento, quase todos os tratamentos com deficiência hídrica 5 dias antes do 
pleno florescimento superaram os tratamentos com deficiência hídrica 10 dias antes, e finalmente quase todos os tratamentos com sementes tratadas com ou sem Pyricularia oryzae, superaram os tratamentos com sementes não tratadas, com ou sem Pyricularia oryzae, evidenciando neste último caso um efeito positivo do Pyroquilon no aumento da porcentagem de grãos em plantas de arroz cujas sementes foram tratadas com esse fungicida. Os resultados obtidos concordam com os comentários de Fageria (1984) no tocante à influência da deficiência hídrica no comportamento da variável estudada. 
Tabela 40. Resumo das estimativas dos contrastes para o grupo de variáveis MGCS (massa de grãos cheios secos), MGCOS (massa de grãos chochos secos), NGC (número de grãos cheios), NGCO (número de grãos chochos) e \% GC (porcentagem de grãos cheios), (segunda fase).

\begin{tabular}{cccccc}
\hline Contrastes & MGCS & MGCOS & NGC & NGCO & $\%$ GC \\
\hline$Y_{1}$ & $-25,54^{* *}$ & $+4,50^{\text {ns }}$ & $+115,00^{\text {ns }}$ & $+710,75^{\text {ns }}$ & $-17,64^{\text {ns }}$ \\
$Y_{2}$ & $-7,65^{* *}$ & $+2,43^{\text {ns }}$ & $-393,25^{\text {ns }}$ & $+789,50^{*}$ & $-25,63^{*}$ \\
$Y_{3}$ & $+78,52^{* *}$ & $-11,29^{* *}$ & $+1345,50^{* *}$ & $-2180,25^{* *}$ & $+82,62^{* *}$ \\
$Y_{4}$ & $-37,16^{* *}$ & $+9,50^{* *}$ & $-1278,00^{* *}$ & $+1503,00^{* *}$ & $-58,76^{* *}$ \\
$Y_{5}$ & $-8,19^{* *}$ & $+2,48^{*}$ & $-470,00^{* *}$ & $+497,50^{* *}$ & $-21,20^{* *}$ \\
$Y_{6}$ & $+71,76^{* *}$ & $-11,22^{* *}$ & $+1193,25^{* *}$ & $-1281,75^{* *}$ & $+55,81^{* *}$ \\
$Y_{7}$ & $-39,15^{* *}$ & $+7,44^{* *}$ & $-823,50^{* *}$ & $+1160,25^{* *}$ & $-48,54^{* *}$ \\
$Y_{8}$ & $-5,43^{* *}$ & $+3,05^{*}$ & $+20,50^{\text {ns }}$ & $+443,75^{*}$ & $-9,96^{*}$ \\
$Y_{9}$ & $-13,70^{* *}$ & $+2,00^{\text {ns }}$ & $-415,25^{\text {ns }}$ & $+944,75^{* *}$ & $-32,68^{* *}$ \\
$Y_{10}$ & $+48,95^{* *}$ & $-10,16^{* *}$ & $+1164,00^{* *}$ & $+2305,50^{* *}$ & $+93,88^{* *}$ \\
$Y_{11}$ & $-34,57^{* *}$ & $+7,93^{* *}$ & $-1524,75^{* *}$ & $+1494,00^{* *}$ & $-65,91^{* *}$ \\
$Y_{12}$ & $-7,33^{* *}$ & $+0,06^{\text {ns }}$ & $-53,25^{\text {ns }}$ & $-28,50^{\text {ns }}$ & $-0,88^{\text {ns }}$ \\
$Y_{13}$ & $+48,04^{* *}$ & $-9,22^{* *}$ & $+1150,75^{* *}$ & $-1481,75^{* *}$ & $+68,39^{* *}$ \\
$Y_{14}$ & $-32,64^{* *}$ & $+4,04^{* *}$ & $-1047,25^{* *}$ & $+809,00^{* *}$ & $-40,98^{* *}$ \\
$Y_{15}$ & $-8,95^{* *}$ & $+2,85^{* *}$ & $-276,75^{* *}$ & $+408,50^{* *}$ & $-17,41^{* *}$ \\
\hline
\end{tabular}

* Significativo pelo teste $\mathrm{F}$, ao nivel de $5 \%$ de probabilidade.

** Significativo pelo teste $\mathrm{F}$, ao nível de $1 \%$ de probabilidade.

ns Não significativo pelo teste F, considerando-se um nível mínimo de significância (n.m.s) de 5\%.

Observa-se na Tabela 40 nitidamente uma certa sistematização nos sinais dos contrastes, iguais para as variáveis MGCS (massa de grãos cheios secos), NGC (número de grãos cheios) e \% GC (porcentagem de grãos cheios) e opostos aos das variáveis MGCOS (massa de grãos chochos secos) e NGCO (número de grãos chochos), o que era esperado, já que são variáveis complementares. Evidencia-se que o melhor tratamento (ou grupo) para MGCS (massa de grãos cheios secos), NGC (número de grãos cheios) e \% GC 
(porcentagem de grãos cheios) seria o pior para MGCOS (massa de grãos chochos secos) e NGCO (número de grãos chochos) e vice-versa.

Os resultados obtidos para a variável porcentagem de grãos cheios (\% GC) são conseqüência do comportamento das variáveis número de grãos cheios (NGC) e número de grãos chochos (NGCO). Quase todos os tratamentos sem deficiência hidrica superaram os tratamentos com deficiência hídrica, quase todos os tratamentos com deficiência hídrica após o pleno florescimento superaram os tratamentos com deficiência hídrica antes do pleno florescimento, quase todos os tratamentos com deficiência hídrica 5 dias antes do pleno florescimento superaram os tratamentos com deficiência hídrica 10 dias antes do pleno florescimento. Também um efeito positivo do Pyroquilon no aumento da porcentagem de grãos cheios (\% GC) pode ser verificado. Os resultados obtidos que correlacionam deficiência hídrica e porcentagem de grãos cheios (\% GC) estão de acordo com Fageria (1984).

O detalhamento da análise para as mesmas variáveis, através de contrastes das médias duas a duas, pelo teste de Duncan, apresentou o seguinte resultado descrito na Tabela 41. 
Tabela 41. Médias sem transformação e teste de Duncan para tratamentos, para as variáveis MGCS (massa de grãos cheios secos), MGCOS (massa de grãos chochos secos), NGC (número de grãos cheios), NGCO (número de grãos chochos) e \% GC (porcentagem de grãos cheios), (segunda fase).

\begin{tabular}{cccccc}
\hline Tratamentos & MGCS & MGCOS & NGC & NGCO & $\%$ GC \\
\hline $\mathrm{T}_{1}$ & $57,75 \mathrm{a}$ & $2,04 \mathrm{def}$ & $1660,50 \mathrm{a}$ & $412,25 \mathrm{fgh}$ & $79,99 \mathrm{ab}$ \\
$\mathrm{T}_{2}$ & $21,29 \mathrm{k}$ & $8,63 \mathrm{a}$ & $764,00 \mathrm{e}$ & $1638,25 \mathrm{a}$ & $32,06 \mathrm{~g}$ \\
$\mathrm{~T}_{3}$ & $29,48 \mathrm{i}$ & $6,15 \mathrm{ab}$ & $1234,00 \mathrm{bc}$ & $1140,75 \mathrm{bc}$ & $53,26 \mathrm{e}$ \\
$\mathrm{T}_{4}$ & $43,97 \mathrm{f}$ & $2,64 \mathrm{def}$ & $1638,00 \mathrm{a}$ & $638,00 \mathrm{def}$ & $72,04 \mathrm{bc}$ \\
$\mathrm{T}_{5}$ & $52,92 \mathrm{bc}$ & $1,71 \mathrm{ef}$ & $1598,00 \mathrm{a}$ & $311,50 \mathrm{gh}$ & $84,13 \mathrm{a}$ \\
$\mathrm{T}_{6}$ & $27,18 \mathrm{ig}$ & $6,45 \mathrm{ab}$ & $929,25 \mathrm{de}$ & $1314,75 \mathrm{ab}$ & $41,42 \mathrm{fg}$ \\
$\mathrm{T}_{7}$ & $34,51 \mathrm{~h}$ & $6,39 \mathrm{ab}$ & $982,50 \mathrm{cde}$ & $1343,25 \mathrm{ab}$ & $42,29 \mathrm{fg}$ \\
$\mathrm{T}_{8}$ & $48,13 \mathrm{de}$ & $2,45 \mathrm{def}$ & $1718,25 \mathrm{a}$ & $582,00 \mathrm{def}$ & $74,81 \mathrm{abc}$ \\
$\mathrm{T}_{9}$ & $57,98 \mathrm{a}$ & $1,45 \mathrm{f}$ & $1720,75 \mathrm{a}$ & $439,50 \mathrm{efgh}$ & $79,70 \mathrm{ab}$ \\
$\mathrm{T}_{10}$ & $24,82 \mathrm{j}$ & $7,96 \mathrm{a}$ & $1196,00 \mathrm{ab}$ & $1282,00 \mathrm{ab}$ & $48,03 \mathrm{ef}$ \\
$\mathrm{T}_{11}$ & $30,24 \mathrm{i}$ & $4,91 \mathrm{bc}$ & $1175,50 \mathrm{bcd}$ & $838,25 \mathrm{~cd}$ & $57,99 \mathrm{de}$ \\
$\mathrm{T}_{12}$ & $47,11 \mathrm{ef}$ & $2,71 \mathrm{def}$ & $1597,50 \mathrm{a}$ & $480,00 \mathrm{efgh}$ & $77,27 \mathrm{ab}$ \\
$\mathrm{T}_{13}$ & $56,12 \mathrm{ab}$ & $1,45 \mathrm{f}$ & $1698,50 \mathrm{a}$ & $2811,25 \mathrm{~h}$ & $85,93 \mathrm{a}$ \\
$\mathrm{T}_{14}$ & $30,19 \mathrm{i}$ & $6,62 \mathrm{ab}$ & $1002,00 \mathrm{bcde}$ & $1114,25 \mathrm{ab}$ & $47,60 \mathrm{ef}$ \\
$\mathrm{T}_{15}$ & $39,14 \mathrm{~g}$ & $3,77 \mathrm{~cd}$ & $1278,75 \mathrm{~b}$ & $705,75 \mathrm{de}$ & $65,01 \mathrm{~cd}$ \\
$\mathrm{~T}_{16}$ & $50,99 \mathrm{~cd}$ & $3,17 \mathrm{cde}$ & $1664,00 \mathrm{a}$ & $505,50 \mathrm{efg}$ & $76,79 \mathrm{ab}$ \\
\hline
\end{tabular}

Médias seguidas de letras iguais, nas colunas, não diferem entre si ao nível de $5 \%$ de probabilidade.

Observa-se que, para as variáveis MGCS (massa de grãos cheios secos) e NGC (número de grãos cheios) a maior média é a do tratamento $T_{9}$ e a menor do $T_{2}$, o inverso ocorrendo para a variável MGCOS (massa de grãos chochos secos). Para a variável NGCO (número de grãos chochos), a maior média foi devida ao tratamento $T_{2}$, como em MGCOS (massa de grãos chochos secos), mas a menor média foi a do tratamento $\mathrm{T}_{13}$.

Para a variável \% GC (porcentagem de grãos cheios), o tratamento que apresentou a maior média foi o $\mathrm{T}_{13}$ seguido do $\mathrm{T}_{5}$ a de menor média foi o $\mathrm{T}_{2}$.

\subsubsection{Número de colmos após a deficiência hídrica}

O detalhamento da análise de variância para as épocas de avaliação está descrito na Tabela 42. 
Tabela 42. Análise da variância e teste $\mathrm{F}$ para a variável número de colmos (NC), (segunda fase).

\begin{tabular}{lcc}
\hline \multicolumn{1}{c}{ C. Variação } & G.L. & Q.M. \\
\hline Tratamentos & 15 & $59,73125^{*}$ \\
Resíduos (A) & 48 & 19,63542 \\
(Parcelas) & $(63)$ & \\
Avaliações & 1 & $7230,03125^{* *}$ \\
Tratamento x Aval. & 15 & $47,83125^{* *}$ \\
Resíduo (B) & 48 & 13,80208 \\
\hline Total & 127 & \\
\hline
\end{tabular}

** Significativo, pelo teste $\mathrm{F}$, ao nível de $1 \%$ de probabilidade.

Observar-se na Tabela 42, que para esta variável número de colmos (NC) foram detectadas diferenças significativas entre tratamentos, entres avaliações e na interação tratamentos versus épocas de avaliações.

O detalhamento da análise da variância através do desdobramento dos graus de liberdade em contrastes ortogonais, pelo teste $F$, estabelecidos na instalação do experimento, apresentou o seguinte resultado descrito na Tabela 43. 
Tabela 43. Desdobramento dos graus de liberdades de tratamentos em contrastes ortogonais, e teste F, para a variável NC (número de colmos), dentro de cada época de avaliação, (segunda fase).

\begin{tabular}{cccc}
\hline Causa da variação & Graus de liberdade & $1^{\text {a }}$. Avaliação & $2^{\text {a }}$ Avaliação \\
\hline $\mathrm{Y}_{1}$ & 1 & $36,00000^{\text {ns }}$ & $60,06250^{\text {ns }}$ \\
$\mathrm{Y}_{2}$ & 1 & $4,50000^{\text {ns }}$ & $84,5000^{*}$ \\
$\mathrm{Y}_{3}$ & 1 & $48,00000^{\text {ns }}$ & $212,52083^{* *}$ \\
$\mathrm{Y}_{4}$ & 1 & $24,00000^{\text {ns }}$ & $26,04167^{\text {ns }}$ \\
$\mathrm{Y}_{5}$ & 1 & $8,00000^{\text {ns }}$ & $15,12500^{\text {ns }}$ \\
$\mathrm{Y}_{6}$ & 1 & $0,33333^{\text {ns }}$ & $391,02083^{* *}$ \\
$\mathrm{Y}_{7}$ & 1 & $10,66667^{\text {ns }}$ & $15,04167^{\text {ns }}$ \\
$\mathrm{Y}_{8}$ & 1 & $\mathbf{8 , 0 0 0 0 0}^{\text {ns }}$ & $0,12500^{\text {ns }}$ \\
$\mathrm{Y}_{9}$ & 1 & $0,50000^{\text {ns }}$ & $0,50000^{\text {ns }}$ \\
$\mathrm{Y}_{10}$ & 1 & $27,00000^{\text {ns }}$ & $243,00000^{* *}$ \\
$\mathrm{Y}_{11}$ & 1 & $0,00000^{\text {ns }}$ & $45,37500^{\text {ns }}$ \\
$\mathrm{Y}_{12}$ & 1 & $0,00000^{\text {ns }}$ & $36,12500^{\text {ns }}$ \\
$\mathrm{Y}_{13}$ & 1 & $5,33333^{\text {ns }}$ & $280,33333^{* *}$ \\
$\mathrm{Y}_{14}$ & 1 & $2,66667^{\text {ns }}$ & $28,16667^{\text {ns }}$ \\
$\mathrm{Y}_{15}$ & 1 & $0,00000^{\text {ns }}$ & $0,50000^{\text {ns }}$ \\
\hline Resíduo & 48 & $19,63542^{\text {ns }}$ & 19,63542 \\
\hline Total & 63 & & \\
\hline
\end{tabular}

* Significativo pelo teste $\mathrm{F}$, ao nivel de $5 \%$ de probabilidade.

** Significativo pelo teste $\mathrm{F}$, considerando-se um nível mínimo de significância (n.m.s) de $5 \%$ de probabilidade.

ns Não significativo pelo teste F, considerando-se um nível mínimo de significância (n.m.s) de $5 \%$ de probabilidade.

Observa-se que, para essa variável, só foram evidenciados contrastes significativos na segunda avaliação, indicando o efeito da interação de tratamentos com as épocas de avaliações. Foram significativos na segunda avaliação os contrastes de tratamentos $\mathrm{Y}_{2}$ (sementes com Pyricularia oryzae, não tratadas versus tratadas), $\mathrm{Y}_{3}$ (sementes com Pyricularia oryzae, não tratadas e sem deficiência hídrica versus com deficiência hídrica), $\mathrm{Y}_{6}$ (sementes com Pyricularia oryzae, tratadas, sem deficiência hídrica versus com deficiência hídrica), $\mathrm{Y}_{10}$ (sementes sem Pyricularia oryzae, não tratadas e sem deficiência 
hídrica versus com deficiência hídrica) e $\mathrm{Y}_{13}$ (sementes sem Pyricularia oryzae, tratadas e sem deficiência hídrica versus com deficiência hídrica).

Tabela 44. Médias sem transformação e teste de Duncan para épocas de avaliações, para a variável NC (número de colmos), (segunda fase).

\begin{tabular}{lc}
\hline \multicolumn{1}{c}{ Épocas } & Médias \\
\hline Final do florescimento ( $1^{\mathrm{a}}$ avaliação) & $18,875 \mathrm{~b}$ \\
Maturação ( $2^{\mathrm{a}}$ avaliação) & $33,906 \mathrm{a}$ \\
\hline
\end{tabular}

Médias seguidas de letras iguais não diferem entre si ao nível de 5\% de probabilidade.

Confirma-se os resultados observados na análise da variância, de diferenças significativas entre as épocas de avaliações da variável NC (número de colmos), evidenciando-se médias significativamente superiores na segunda avaliação (maturação) (Tabela 44).

O detalhamento da análise para a variável NC (número de colmos), dentro de cada época de avaliação, através de contrastes das médias duas a duas, pelo teste Duncan, apresentou o seguinte resultado, descrito na Tabela 45. 
Tabela 45. Médias sem transformação e teste de Duncan, para os tratamentos dentro de cada avaliação, da variável NC (número de colmos), (segunda fase).

\begin{tabular}{|c|c|c|}
\hline Tratamentos & $1^{\mathrm{a}}$ Avaliação & $2^{\mathrm{a}}$ Avaliação \\
\hline $\mathrm{T}_{1}$ & 17,00 ab & 28,25 cde \\
\hline$T_{2}$ & 21,00 ab & 37,00 \\
\hline $\mathrm{T}_{3}$ & 23,00 & $34,25 \quad a b c$ \\
\hline $\mathrm{T}_{4}$ & $19,00 \quad a b$ & 38,75 \\
\hline $\mathrm{T}_{5}$ & $16,00 \quad b$ & 28,25 cde \\
\hline$T_{6}$ & $19,00 \quad a b$ & $36,50 \quad a b$ \\
\hline $\mathrm{T}_{7}$ & $19,00 \quad a b$ & $40,75 \quad a$ \\
\hline$T_{8}$ & $19,00 \quad a b$ & 34,50 abc \\
\hline$T_{9}$ & $19,00 \quad a b$ & $22,75 \quad \mathrm{e}$ \\
\hline$T_{10}$ & $21,00 \quad a b$ & $33,50 \mathrm{bcd}$ \\
\hline $\mathrm{T}_{11}$ & $19,00 \quad a b$ & $33,25 \mathrm{bcd}$ \\
\hline $\mathrm{T}_{12}$ & $18,00 \quad a b$ & $35,75 a b$ \\
\hline $\mathrm{T}_{13}$ & $19,00 \quad a b$ & 27,50 de \\
\hline $\mathrm{T}_{14}$ & $18,00 \quad a b$ & $38,00 \mathrm{ab}$ \\
\hline $\mathrm{T}_{15}$ & $18,00 \quad a b$ & $38,50 \mathrm{ab}$ \\
\hline$T_{16}$ & $17,00 \quad a b$ & $35,00 \mathrm{ab}$ \\
\hline
\end{tabular}

Médias seguidas de letras iguais nas colunas, não diferem entre si ao nível de $5 \%$ de probabilidade.

Observa-se claramente, pela Tabela 45, o comportamento diferente dos tratamentos de dentro de cada época (final do florescimento e maturação). Na primeira avaliação (final do florescimento) a única diferença detectada pelo teste de Duncan foi entre os tratamentos $\mathrm{T}_{3}$ (maior média) e $\mathrm{T}_{5}$ (menor média), respectivamente, sementes com Pyricularia oryzae, não tratadas e com deficiência hídrica 5 dias após pleno florescimento, e sementes sem Pyricularia oryzae, não tratadas e sem deficiência hídrica. Na segunda avaliação (maturação), foram detectadas várias diferenças entre os tratamentos, ficando a maior média com $\mathrm{T}_{7}$ (sementes sem Pyricularia oryzae, não tratadas e com deficiência hídrica 5 dias antes do pleno florescimento) e a menor com o T9 (sementes com Pyricularia oryzae, tratadas e sem deficiência hídrica).

Os resultados obtidos para a variável NC (número de colmos) após a deficiência hídrica, evidenciam que existe uma divisão em dois grupos de tratamentos os com deficiência hídrica e os sem deficiência hídrica. Os tratamentos sem deficiência hídrica apresentaram os menores números de colmos estatisticamente iguais entre si, já os tratamentos com deficiência hídrica apresentaram os maiores números de colmos, e também estatisticamente iguais entre si. O maior perfilhamento dos tratamentos com deficiência 
hídrica deu-se devido à influência do reinício da irrigação e o novo desenvolvimento que as plantas foram submetidas à partir desse reinício, já os tratamentos sem deficiência hídrica apresentaram um desenvolvimento normal das plantas. 


\section{CONCLUSÃo}

Nas condições do presente experimento, os resultados obtidos permitem concluir:

O Pyroquilon, quando aplicado em tratamento de sementes de arroz de sequeiro, controla eficazmente os patógenos presentes nas sementes: Pyricularia oryzae, Helminthosporium oryzae, Rhinchosporium oryzae, Penicillium spp., Phoma sp., Trichoconiella padwickii e Fusarium sp., não controlando Aspergillus spp.

O Pyroquilon tem influência positiva mesmo quando as sementes não estão contaminadas por Pyricularia oryzae Cav., estimulando o desenvolvimento vegetativo, atuando como um fitoestimulante, no entanto quando ocorrem períodos de deficiência hídrica, particularmente próximo ao pleno florescimento, o efeito fitoestimulante do Pyroquilon não é suficiente para compensar os efeitos deletérios da deficiência hídrica. 


\section{REFERÊNCIAS BIBLIOGRÁFICAS}

AMARAL, H.M. DO; RIBEIRO, A.S.; LUCCA FILHO, O.A. Diagnóstico da Patologia de Sementes de Arroz no Brasil. Revista Brasileira de Sementes, Brasília, n. 1, p.138-187, 1985.

BISWAS, A.K. Jr.; NAYEK, B.; CHOUDHURI, M.A.. Effect of calcium on the response of a field-grown rice plant to water stress. Proceedings of the Indian National Science Academy. V. 48, n. 5, 699-705, (CAB Abstracts on CD-ROM), 198486.

CHANG, T.; VERGARA, B.S. Varietal diversity and morpho-agronomic characteristics of upland rice. Major Research in upland Rice. Los Banos, IRRI, 1975, p.72-90.

CIBA-GEICY AG. Compedium of Growth Stage Identification Keys for Mono and Dicotyledoneus Plants. Extended BBCH Scale. Basle, Ciba-Geigy, 1994. 94p.

CIBA-GEIGY QUÍMICA S.A., São Paulo. FONGORENE - Boletim Técnico. São Paulo, 1990. 12p.

CICERO, S.M.; CHAMMA, H.M.P.; NOVEMBRE, A.D.L.C.; MORAES, M.H.D. Qualidade Fisiológica e Sanitária de Sementes de Arroz Submetidas à Diferentes Tratamento Fungicidas. In: Congresso Brasileiro de Sementes, 7. Foz do Iguaçu, 1993. Informativo Abrates, Brasília, V. 3, p.95, Junho, 1993.

CORNÉLIO, V.M. de O. Efeito de aplicações de fungicidas em semente e parte aérea do arroz (Oryza sativa L.) sobre a qualidade fisiológica e sanitária das sementes produzidas. Lavras, 1991, 82p. (Dissertação de Mestrado - Escola Superior de Agricultura de Lavras). 
DHINGRA, O.D.; MUCHOVEJ, J.J.; CRUZ FILHO, J. DA. Tratamento de Sementes. Viçosa, Universidade Federal de Viçosa. 1980. 121p.

FAGERIA, N.K. Adubação e Nutrição Mineral da Cultura do Arroz. Rio de Janeiro, Campus, 1984. 340p.

FILIPPI, M. C.; PRABHU, A.S. Fongorene - Boletim Técnico. Ciba-Geigy Química S.A São Paulo, 1989. 8p.

FONSECA, J. R.; BEBENDO, I.P. Características Morfológicas, Agronômicas e Fenológicas de Algumas Cultivares de Arroz. EMBRAPA-CNPAF. Goiânia, 1984. 58p.

FORCELINI, C.A. A importância do Tratamento de Sementes. Correio Agrícola, Șão Paulo, n. 2, p.2-5, 1990.

FORNASIERI FILHO, D.; FORNASIERI, J. L. Manual da Cultura do Arroz. Jaboticabal, FUNEP, 1993. 221p.

GALLI, F.; CARVALHO, P. DE C. T. DE. C.; TOKESHI, H.; BALMER, H.; KIMATI, H.; CARDOSO, C.O.N.; SALGADO, C.L.; KRUGNER, T.L.; CARDOSO, E.J.V.N.;

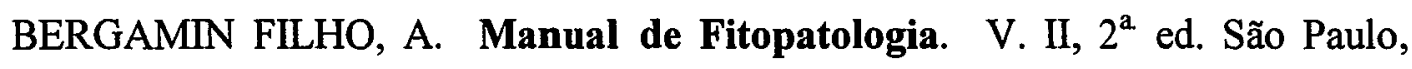
Ceres, 1980.587 p.

JEFFS, K.A. Seed Treatment. $2^{\text {nd. }}$ ed. Surrey - England, British Crop Protection Council, 1986. 332p.

KRISHNASAMY, V.; SESHU, D.V. Seed Treatment in Rice. Journal of Seed Technology, v.11, n.1, p.69-78, 1987. 
LASCA, C.C.; BRIGNANI NETTO, F.; CHIBA, S. Eficiências de fugicidasem tratamento de sementes de arroz para controle de Pyricularia oryzae Cav. e Phoma sp. Summa Phytopathologica, v. 9, p.93-94, janeiro-junho, 1983.

LUCCA, A.O. Importância da Sanidade na Produção de Sementes de Alta Qualidade. Revista Brasileira de Sementes, Brasília, n. 1, p.113-123, 1985.

MA, Y.F.; LU, DZ. Effect of irrigation methods on senescence and physiological activities in hybrid rice after heading. Chinese Journal of Rice Science, v. 4, n. 2, p.56-62, (CAB Abstracts on CD-ROM), 1990-91.

MARCOS FILHO, J.; CICERO, S.M.; DA SILVA, W.R. Avaliação da Qualidade das Sementes. Piracicaba, FEALQ, 1987. 230p.

MENEZES, J.R. de. Estabelecimento de Tolerância à Patógenos Associados à Sementes. Revista Brasileira de Sementes, Brasília, n. 1, p.31-32, 1985.

MINISTÉRIO DA AGRICULTURA E REFORMA AGRÁRIA. Regras para Análise de Sementes. Brasília, MARA, 1992. 365p.

NAKAMURA, A.M.; SADER, R. Efeito da Infecção por Fungos na Germinação e Vigor de Sementes de Arroz. Revista Brasileira de Sementes, Brasília, n. 1, p.101$109,1986$.

O'TOOLE, J.C. \& GARRITY, D.P. Upland rice soil-plant-water relationships In: SWAMINATHAN, M.S. An Overview of upland Rice Research. Los Banos, IRRI, 1984, p.395-411.

OU, S.H. Rice Diseases. Great Britain, Second Edition, 1985, 380p. 
PEARCE, R.B.; MOCK, J.J.; BAILEY, T.B. Rapid method for estimating leaf area per plant in maize. Crop Science, v.15, p.691-4, 1975.

PEREIRA, J.A.; SOBRINHO, J.T.; BELTRÃO N.M. de M. Respostas de cultivares melhoradas de arroz de sequeiro a diferentes níveis de umidade. Pesquisa Agropecuária Brasileira. Brasília, v.29, n. 6, p.857-865, junho, 1994

PINHEIRO, B. da S.; GUIMARÃES, E.P. Índice de área foliar e produtividade do arroz de sequeiro - I Níveis Limitantes. Pesquisa Agropecuária Brasileira. Brasília, v.25, n.6, p.863-872, junho, 1990

PINHEIRO, B. da S.; MARTINS, J.F. da S.; ZIMMERMANN, F.J.P. Índice de área foliar e produtividade do arroz de sequeiro - II manifestação através dos componentes da produção. Pesquisa Agropecuária Brasileira. Brasília, v.25, n.6, p.873-879, junho, 1990.

PRABHU, A.S.; FILIPPI, M.C. Seed treatment with pyroquilon for the control of leaf blast in brazilian upland rice. International Journal of Pest Management, 39(3), p.347-353, 1993.

PRABHU, A.S.; GUIMARÃES, E.P. Estratégia de controle da Pyricularia oryzae em arroz de sequeiro. Summa Phytopathologica. V. 16, n. 1, p.47-56, janeiro-março, 1990.

RENARD, C.; ALLURI, K. Leaf Water potential, stomatal conductances and leaf characteristics of cultivars of rice in their response to water. Acta Ecologica/ Ecologia Plantarum, 2(16), n.4, p. 339:349, 1981. 
SARTORATO, A. \& MENTEN, J.O.M. Controle Químico de Phoma sp. em Sementes de Arroz (Oryza sativa L.). Revista Brasileira de Sementes. Brasilia, n. 2, p.59-65, 1990.

SEN, A.; MISRA, N.M. Correlation-coefficient between yield and some drought tolerance capacity measuring parameters in 'Kalyan Sona' wheat. Food Farming and Agriculture. V. 14, p.1-2, (CAB Abstracts on CD-ROM), 1984-86.

SHAHJAHAN, A.K.M.; DUVE, T.; BOMMAN, J.M. Climate and rice diseases. In: SWAMINATHAN, M.S. Rice and Weather. Los Banos, IRRI, 1987, 125-138p.

SOAVE, J.; WETZEL, M.M.V. DA S., ed. Patologia de Sementes. Campinas, Fundação Cargill, 1987. 480 p.

SOUZA, A.J. de; BRIGNANI NETO, F.; SOAVE J. Principais Doenças da Cultura do Arroz. Campinas, fevereiro, 1984 (Boletim Técnico CATI, n. 182).

STONE, L.F.; LIBARDI, P.L.; REICHARDT, K. Deficiência hídrica, vermiculita e cutivares. I Efeito na produtividade do arroz. Pesquisa Agropecuária Brasileira. Brasília, v.19, n.6, p.695-707, junho, 1984.

VIEIRA, A.R.R.; STEINMETZ, S.; BRUNINI, O. Resposta de duas cultivares de arroz de sequeiro a níveis de água no solo. Pesquisa Agropecuária Brasileira. Brasília, v.26, n.7, p.927-934, jul, 1991.

WANG, X.; SHEN, B. The effect of soaking seed with multi-effect triazole on drought resistance in rice seedlings. Acta Phytophysiologica Sinica. 1991, v. 17, n. 1, p. 105-108. (Abstracts on CD-ROM), 1992. 